\title{
A contribuição da indústria da manufatura no desenvolvimento de software
}

\author{
Eduardo Teruo Katayama \\ DissertaÇÃo APRESENTADA \\ AO \\ Instituto De Matemática e Estatística \\ DA \\ Universidade de São Paulo \\ PARA \\ OBTENÇÃO DO TÍTULO \\ $\mathrm{DE}$ \\ Mestre Em CiÊnCIAS \\ Programa: Ciência da Computação \\ Orientador: Prof. Dr. Alfredo Goldman vel Lejbman
}

Durante o desenvolvimento deste trabalho o autor recebeu auxílio financeiro do CNPq

São Paulo, março de 2010 


\title{
A contribuição da indústria da manufatura no desenvolvimento de software
}

\author{
Este exemplar corresponde à redação \\ final da dissertação/tese devidamente corrigida \\ e defendida por Eduardo Teruo Katayama \\ e aprovada pela Comissão Julgadora.
}

Banca Examinadora:

- Prof. Dr. Alfredo Goldman ve Lejbman (orientador) - IME-USP.

- Prof. Dr. Jose Reinaldo Silva - EP-USP.

- Prof. Dr. Rafael Prikladnicki - PUC-RS. 


\section{Agradecimentos}

Agradeço à minha família e minha noiva, por todo carinho, apoio e incentivo.

Ao meu orientador, Prof. Dr. Alfredo Goldman, pela confiança, incentivo e apoio durante todo o longo percurso deste mestrado e, principalmente, pela amizade.

A todos os amigos do IME, por compartilhar o aprendizado durante todos os anos desde a graduação. Em particular, aos amigos que estiveram mais próximos durante o mestrado.

Por fim, a todos que contribuíram de forma direta ou indireta na realização deste trabalho.

\section{Muito obrigado!}




\section{Abstract}

Agile methods appeared in the late 90's as an alternative approach to the classic prescriptive planning approaches to software development. They propose a new style of development, eliminating excessive and bureaucratic documentation, and emphasizing the interactions between people collaborating to achieve high productivity and deliver high-quality software.

In the last few years, several principles and practices based on the manufacturing industry were incorporated by Agile software development. One of the principles absorbed is to improve the effectiveness of an organization through an overall improvement. Although this principle is quite widespread in Agile Methods, using it is not an easy task. It is not easy to get the big picture of the development process. Moreover, to achieve overall improvements is necessary to discover the cause of possible problems, which can also be a difficult task.

This work investigates two approaches in the manufacturing industry that shares the assumption that the whole organization is focused on overall throughput, not on micro-optimization. Based on then, three approaches to existing software development are analyzed. Finally, a comparative study was done to assess the main characteristics of the studied methods. This study extends the work

done by Abrahamssom et al. In the book emph Agile Software Development: Current Research and Future Directions, evaluating the performance of the methods following the framework proposed by the same authors. 


\section{Resumo}

Os Métodos Ágeis surgiram no final da década de 90, como uma alternativa aos métodos prescritivos de desenvolvimento de software. Eles propõem uma nova abordagem de desenvolvimento, eliminando gastos com documentação excessiva e burocrática, enfatizando a interação entre as pessoas e as atividades que efetivamente trazem valor ao cliente.

Nos últimos anos, diversos princípios e práticas baseados na indústria de manufatura foram incorporadas pelos Métodos Ágeis de desenvolvimento de software. Um dos princípios absorvidos é o de melhorar a eficácia de uma organização através de melhorias globais. Embora este princípio seja bem difundido nos Métodos Ágeis, utilizá-lo não é uma tarefa fácil. Nem sempre é fácil ter uma visão global do processo de desenvolvimento. Além disso, para realizar melhorias globais é necessário descobrir a causa para possíveis problemas, o que também pode ser uma tarefa difícil.

Esse trabalho investiga duas abordagens da indústria de manufatura que enxergam uma organização como um sistema no qual todas as partes são inter-relacionadas. Com base nelas, três abordagens de desenvolvimento de software existentes são analisadas. Finalmente, um estudo comparativo foi feito para avaliar as principais características dos métodos de desenvolvimento estudados. Esse estudo estende o trabalho feito por Abrahamssom et al., no livro Agile Software Development: Current Research and Future Directions, avaliando o desempenho dos métodos seguindo o arcabouço proposto pelos mesmos autores. 


\section{Sumário}

1 Introdução $\quad 1$

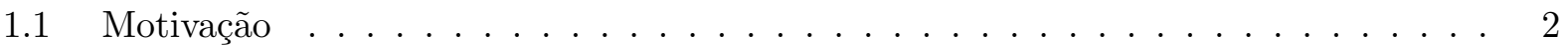

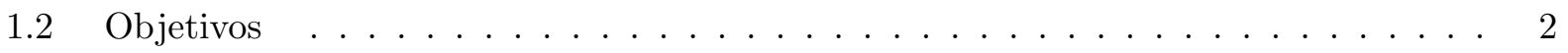

1.3 Organização do Trabalho . . . . . . . . . . . . . . . . . . . 2

2 Métodos de desenvolvimento da indústria de manufatura 5

2.1 Manufatura Lean . . . . . . . . . . . . . . . . . . . . . . . . 5

2.1 .1 Histórico . . . . . . . . . . . . . . . . . . 5

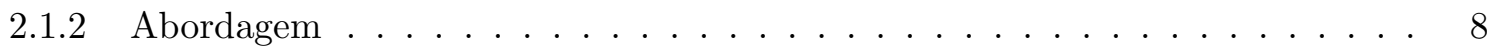

2.1 .3 Princípios . . . . . . . . . . . . . . . . . . . . . 9

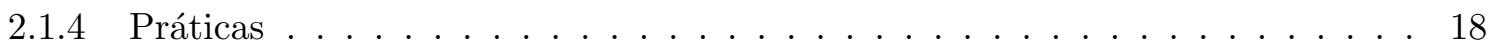

2.1 .5 Conclusão . . . . . . . . . . . . . . . . . . . . . 22

2.2 Teoria das Restrições . . . . . . . . . . . . . . . . . . . . . . . . . 23

2.2 .1 Histórico . . . . . . . . . . . . . . . . . . . . 23

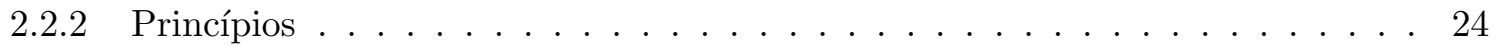

2.2 .3 Processo de Raciocínio . . . . . . . . . . . . . . . . . . . 25

2.2 .4 Práticas . . . . . . . . . . . . . . . . . . . 32

2.2 .5 Conclusão . . . . . . . . . . . . . . . . . . . . 37

2.3 A importância de uma visão global . . . . . . . . . . . . . . . . . 37

3 Métodos de desenvolvimento de software 41

3.1 Lean Software Development . . . . . . . . . . . . . . . . . . . . . . . 42

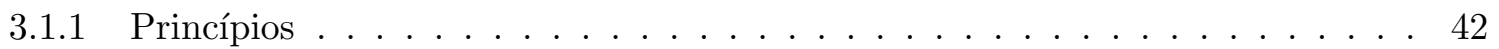

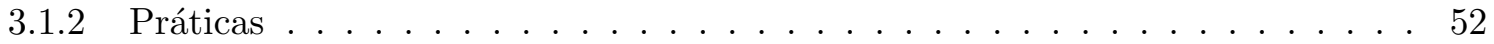

3.1 .3 Formas de adoção . . . . . . . . . . . . . . . . . 6 . . . . . . . . . . . .

3.2 Teoria das Restrições . . . . . . . . . . . . . . . . . . . . . . . 63

3.2.1 A Corrente Crítica no desenvolvimento de software . . . . . . . . . . . 64

3.2.2 Tambor-pulmão-corda no desenvolvimento de software . . . . . . . . . 66

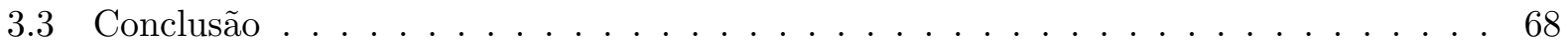

3.3 .1 Lean Software Development . . . . . . . . . . . . . . 69

3.3 .2 Teoria das Restrições . . . . . . . . . . . . . . . . . . . . . 70 
4 Estudo comparativo $\quad 71$

4.1 Arcabouço de Abrahamsson . . . . . . . . . . . . . . . . . . 71

4.2 Comparativo dos Métodos Ágeis baseados na indústria de manufatura . . . . . . . . 72

4.2.1 Suporte a gerenciamento de projeto . . . . . . . . . . . . . . . 72

4.2 .2 Ciclo de vida do desenvolvimento de software . . . . . . . . . . . . . 73

4.2.3 Disponibilidade de orientações concretas para utilização . . . . . . . . . . . . 73

4.2 .4 Adaptabilidade na utilização . . . . . . . . . . . . . . . . . . . . . . . . . . . . . . . . .

4.2.5 Propósito da metodologia . . . . . . . . . . . . . . . . . . 74

4.2 .6 Evidências empíricas . . . . . . . . . . . . . . . . . 75

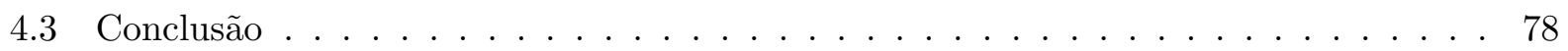

5 Lean Startup $\quad \mathbf{8 1}$

5.1 Aproximando o desenvolvimento de software às necessidades do cliente . . . . . . 81

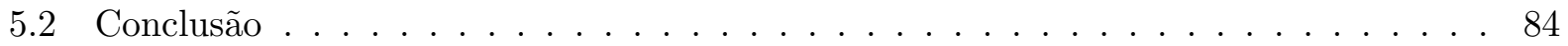

6 Considerações finais $\quad \mathbf{8 5}$

6.1 Contribuições . . . . . . . . . . . . . . . . . . . . . . 85

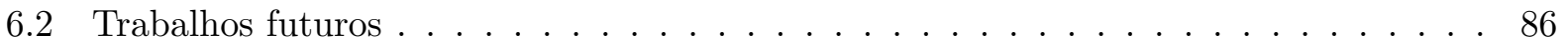

$\begin{array}{ll}\text { A Métodos Ágeis } & 87\end{array}$

A.1 O Manifesto Ágil . . . . . . . . . . . . . . . . . . . . . . 87

A.2 Programação Extrema . . . . . . . . . . . . . . . . . . 88

A.3 Scrum . . . . . . . . . . . . . . . . . . . . . . 89

A.4 Família Crystal . . . . . . . . . . . . . . . . . . 90

Referências Bibliográficas $\quad 93$ 


\section{Capítulo 1}

\section{Introdução}

Nas últimas décadas, com o surgimento da Internet e dos aplicativos móveis, a indústria de software teve um processo de expansão e amadurecimento significativo tornando-se uma das mais importantes do mundo. Junto com a expansão, mudaram também as necessidades para o desenvolvimento do software. No competitivo mercado de software, velocidade e flexibilidade são essenciais [TN86]. Para atender às novas necessidades de negócio é preciso inovar e criar uma nova cultura de desenvolvimento de software [HC01].

As primeiras abordagens para desenvolvimento de software almejaram criar um processo previsível e eficiente, para isso, elas se inspiraram na disciplina prescritiva da engenharia que possuía uma abordagem com forte ênfase no planejamento. No entanto, apesar dos esforços para definir processos e métodos cada vez mais burocráticos e rigorosos, o contato com requisitos instáveis e a falta de envolvimento de usuários fizeram com que os diversos modelos de desenvolvimento de software se mostrassem inapropriados [Gro94]. Alguns processos tentaram mapear com abrangência as etapas do desenvolvimento, resultando em modelos como o Unified Process [BJR99]. Modelos de avaliação de qualidade de processo foram criados para validar a aplicação dos processos, como o Capability Maturity Model Integration (CMMI) da Carnegie Mellon [CLDL99]. Porém, apesar das boas intenções dessas iniciativas, todas abordam o desenvolvimento de software como um processo que pode ser repetido mecanicamente, tentando enquadrá-lo em uma linha de produção.

A analogia entre a disciplina prescritiva da engenharia e o desenvolvimento de software não é muito adequada [Sat07]. Cockburn sugere que o desenvolvimento de software depende muito mais das pessoas e da comunicação [Coc06]. Larman sugere que, ao contrário do cenário numa linha de produção em massa, o software não é algo previsível ou imune a mudanças [Lar04]. Desenvolver software é como criar uma receita, enquanto produzir é seguir os passos de uma receita [PP03]. O desenvolvimento é um processo de aprendizado, que envolve tentativas e erros.

Foi a partir desse novo paradigma, que surgiram os Métodos Ágeis de Desenvolvimento de Software. Eles propõem uma nova abordagem de desenvolvimento, eliminando gastos com documentação excessiva e burocrática, enfatizando a interação entre as pessoas e as atividades que efetivamente trazem valor ao cliente $\left[\mathrm{BBvB}^{+} 01\right]$.

Nos últimos anos, diversos princípios e práticas baseados na indústria de manufatura foram incorporadas pelos Métodos Ágeis de desenvolvimento de software. Um dos princípios absorvidos 
é o de melhorar a eficácia de uma organização através de melhorias globais. Embora este princípio seja bem difundido nos Métodos Ágeis, utilizá-lo não é uma tarefa fácil. Nem sempre é fácil ter uma visão global do processo de desenvolvimento. Além disso, para realizar melhorias globais é necessário descobrir a causa para possíveis problemas, o que também pode ser uma tarefa difícil.

Atualmente, os Métodos Ágeis são utilizados em diversos segmentos da indústria para construir uma variedade de sistemas e aplicações de software. Sua adoção têm crescido substancialmente, tornando-se uma das abordagens predominantes no desenvolvimento de software [WGGD10]. Os Métodos Ágeis são descritos em mais detalhes no Apêndice A.

\subsection{Motivação}

Introduções e apresentações acadêmicas sobre os diversos métodos de desenvolvimento ágeis existentes foram feitos por diversos pesquisadores [ASRW02, CMS04, ELS05, DD08, AOS10]. Praticantes dos métodos ágeis produziram diversos trabalhos sobre Lean Software Development [Pop07, Mid01, Pop02a, MFC05] e Teoria das Restrições [And04b, AD05], entretanto, nenhum desses trabalhos apresenta uma revisão unificada sobre os métodos de desenvolvimentos de software baseados na indústria de manufatura.

Um problema observado por Abrahamssom et al. é que a falta de uma pesquisa unificada dificulta o estabelecimento de uma tradição de pesquisa confiável e cumulativa [AOS10]. Nesse sentido, os objetivos derivados das motivações dessa dissertação serão descritos a seguir.

\subsection{Objetivos}

O principal objetivo deste trabalho é criar um texto que sirva como referência de Lean e Teoria das Restrições em Métodos Ágeis. Para isso descrevemos os princípios e práticas dos principais métodos da manufatura com clara influência na comunidade de Métodos Ágeis. Em seguida, mostramos como esses métodos podem ser adaptados ao desenvolvimento de software.

Por fim, esse trabalho analisa e classifica o desempenho dos métodos estudados utilizando as perspectivas propostas pelo arcabouço de Abrahamsson et al. [AOS10] que visa identificar as principais características dos métodos de desenvolvimento, analisando os seus pontos fortes e fracos.

\subsection{Organização do Trabalho}

Este trabalho está organizado da seguinte forma: no Capítulo 2, duas abordagens da indústria da manufatura que ganharam importância no desenvolvimento de software são apresentadas. No Capítulo 3, os modelos de desenvolvimento baseados na indústria de manufatura são apresentados, com enfoque em Métodos Ágeis. No Capítulo 4, um estudo comparativo dos métodos de desenvolvimento baseados na indústria de manufatura é apresentado, avaliando-os com as seguintes perspectivas: suporte a gerenciamento de projeto; ciclo de vida do desenvolvimento de software; disponibilidade de orientações concretas para utilização; adaptabilidade na utilização; propósitos da metodologia e evidências empíricas. No Capítulo 5, apresentamos uma tendência futura para um desenvolvimento de software mais próximo às necessidades do cliente. Por fim, este trabalho é concluído no Capítulo 6, destacando as contribuições e apresentando possibilidades para trabalhos 
futuros. Para os interessados em Métodos Ágeis, o Apêndice A apresenta seus valores, princípios e principais métodos de desenvolvimento de software. 


\section{Capítulo 2}

\section{Métodos de desenvolvimento da indústria de manufa- tura}

Nos últimos anos, duas abordagens da manufatura ganharam importância no desenvolvimento de software: A Teoria das Restrições e a Manufatura Lean. Essas duas abordagens possuem um conjunto de técnicas e princípios que visam melhorar a produtividade de organizações através de melhorias contínuas no fluxo de desenvolvimento.

Neste capítulo, apresentamos os princípios e práticas dessas duas abordagens, oferecendo uma visão ampla sobre o tema, sem discutir os detalhes de cada método. O objetivo é expor o contexto e motivação das práticas, possibilitando dessa forma adaptá-las ao desenvolvimento de software.

\subsection{Manufatura Lean}

O termo Lean ${ }^{1}$ surgiu em 1990 para descrever o processo de produção desenvolvido e utilizado pela Toyota que tem como base a eliminação contínua de desperdício [Ohn88]. O Sistema de Produção da Toyota propõe a melhoria da produtividade através da criação de um fluxo contínuo de produção baseado na demanda real do cliente. Através da melhoria do fluxo é possível eliminar o uso de recursos que não agregam valor para o cliente, permitindo uma produção mais flexível e com menos defeito ao mesmo tempo em que os custos são significativamente reduzidos [WJ03]

Embora o Sistema Toyota de Produção esteja em constante evolução, muitos dos princípios podem ser identificados desde os primórdios da companhia. Portanto, para entender a Manufatura Lean é útil estudar a história dos fundadores do Sistema Toyota de Produção, que deixaram uma marca permanente na cultura da empresa através de uma excepcional consistência de liderança e filosofia no decorrer da sua história.

\subsubsection{Histórico}

O Sistema de Produção da Toyota (Toyota Production System - TPS) tem sua origem nas máquinas de tear de Sakichi Toyoda. Em 1896, Sakichi começou a criar máquinas de tear mecânicas, entretanto, as primeiras máquinas eram complexas, possuíam baixa precisão e eram difíceis de manipular [MR96]. Para mudar este cenário, Sakichi contratou Charles A. Francis, um professor americano de engenharia da Tokyo Higher Technical School. Charles reorganizou a linha de mon-

\footnotetext{
${ }^{1} \mathrm{O}$ termo refere-se ao fato da Toyota utilizar menos recursos e tempo do que seus concorrentes para produzir produtos de alta qualidade [WJR91].
} 
tagem e remodelou os equipamentos para que as peças fossem uniformes e intercambiáveis. Após alguns anos, o lucro e as vendas cresceram atingindo recordes [Mag07](pág. 12).

Em 1921, Kiichiro Toyoda entrou para a companhia de seu pai e ficou responsável pela automação das máquinas de tear. Em 1924, Sakichi e Kiichiro criaram a máquina de tear automática G-Type, apresentada na Figura 2.1, que possuía um mecanismo que parava automaticamente a máquina quando um fio quebrava, evitando assim que ocorressem desperdícios de material ao se criar produtos defeituosos. Esse mecanismo ficou conhecido como Jidoka, automação com um toque humano.

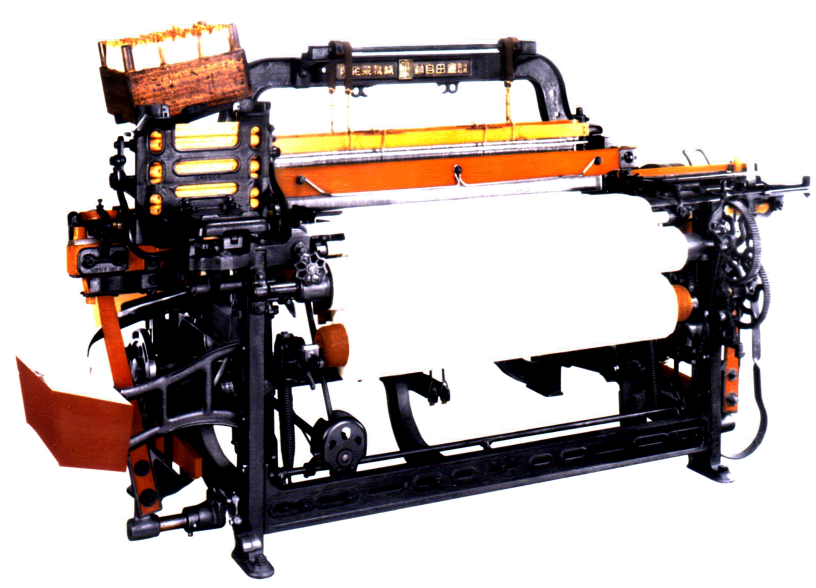

Figura 2.1: Tear G-Type automatic loom.Fonte: http://www.jpo.go.jp/seido_e/rekishi_e/sakichi_toyoda.htm

Apesar do Jidoka ser a característica mais lembrada pelos praticantes de Lean, a máquina G-Type possuía outras características importantes, como um sofisticado mecanismo de troca de agulhas que evitava que ela fosse parada durante a troca de agulhas, esse mecanismo diminuía consideravelmente o tempo gasto na preparação da máquina (setup).

Ao eliminar a criação de produtos defeituosos com o Jidoka e diminuir os desperdícios no processo, Sakichi fez com que a máquina G-Type fosse um sucesso absoluto, melhorando tanto a produtividade, quanto a eficiência do trabalho. Posteriormente, os direitos da máquina G-Type foram vendidos para a Platt Brothers e o dinheiro obtido foi utilizado na criação de uma nova divisão da empresa, a Toyota Motor Corporation [Fuj99].

Inicialmente, a Toyota Motor Corporation ${ }^{2}$ fabricava apenas caminhões com tecnologia ultrapassada. Para melhorar esse cenário, os líderes da Toyota estudaram as linhas de montagem americanas e os livros de Henry Ford sobre produção em massa. Em 1956, após Eiji Toyoda e Taiichi Ohno visitarem as plantas automobilísticas americanas a fim de melhorar o processo de desenvolvimento, eles concluíram que o sistema de produção em massa não poderia ser aplicado no Japão, pois:

\footnotetext{
${ }^{2}$ A mudança da letra "d" pela letra "t" em Toyoda foi feita para que a última sílaba ficasse mais suave, além de ser pronunciada mais facilmente pelos norte-americanos. A escrita de Toyota em katakana precisa de oito traços ao invés dos dez de Toyoda - o oito é considerado um número da sorte no Japão - e o formato dos caracteres simbolizam crescimento e prosperidade [Mag07](pág. 16).
} 
- O sistema de produção em massa era projetado para produzir grandes quantidades de um mesmo produto. No entanto, o mercado doméstico japonês era limitado e exigia uma variedade muito grande de automóveis - veículos para indústria e agricultura, veículos luxuosos e carros populares;

- A economia japonesa estava devastada após a derrota na Segunda Guerra Mundial, o que impedia o Japão de ter recursos como os norte-americanos para investir em grandes máquinas;

- O espaço de armazenamento, abundante nas empresas americanas, era outro problema para os japoneses.

A conclusão de Eiji e Ohno foi de que o sistema de produção da Toyota deveria ser adaptado para alcançar alta qualidade, baixo custo, entrega rápida e flexibilidade. Apesar deles terem descoberto que o sistema de produção em massa não poderia era adequado no mercado japonês, foi durante a mesma viagem que Ohno obteve a inspiração para a criação do processo de desenvolvimento pull ao observar o funcionamento do supermercado. Ele ficou impressionado com a forma que os clientes escolhiam exatamente o que queriam, na quantidade que eles desejavam. Ohno admirou o modo como os supermercados forneciam os produtos de forma simples, eficiente e oportuna.

Através de estudos das linhas de montagem americanas e dos livros de Henry Ford, assim como suas observações do funcionamento de reposição de estoque em supermercados, Ohno obteve a inspiração necessária para a criação de técnicas para eliminar desperdícios entre operações e linhas de processos. Este modo de operar fez com que os materiais só chegassem na linha de montagem quando fossem absolutamente necessários, ficando conhecido internamente na Toyota por Just-inTime. Com uma série de experimentos que se mostraram revolucionários [Sma], Ohno induziu os trabalhadores a utilizarem diversas máquinas simultaneamente, enquanto eliminava a tradição de estocar inventário de estoque em processo (work-in-process).

Com o passar dos anos, Ohno frequentemente descreveu seu sistema de produção em termos de supermercados americanos. Estes possuíam a seguinte abordagem [Pop01]: nas prateleiras eram colocadas pequenas quantidade de todos os tipos de produtos disponíveis, quando um cliente retirava um produto da prateleira, ela era rapidamente reabastecida.

Nesse sistema, conhecido como Sistema Pull, a necessidade das linhas seguintes ditam o ritmo de produção. Esse modo de operar contrasta com o sistema prescritivo, conhecido como Sistema Push, que é guiado pela produção das linhas anteriores. Para operar o Sistema de Produção Pull, Ohno desenvolveu um conjunto de ferramentas. Entre elas destaca-se o Kanban, que fornece um modo para transmissão de informações dentro e entre processos através de cartões de instruções [TMMK06].

Posteriormente, Shingo foi trabalhar com Ohno e juntos se concentraram no problema de setup, reduzindo o tempo médio de horas a minutos. Isto permitiu o uso de pequenos lotes e um quase perfeito fluxo contínuo. Esta forma de produção possibilitou uma flexibilidade na produção de diversos produtos, ao contrário do sistema da Ford que sempre produzia apenas um tipo de produto [Inc]. Posteriormente, Shingo publicou um livro [Shi85] no qual explicava o método e a razão para diminuir o tamanhos do lotes. 
Posteriormente, com base na pesquisa sobre o Sistema Toyota de Produção, James Womack e Daniel Jones publicaram o livro The Machine That Changed the World [WJR91] dando um novo nome ao que antes era conhecido como TPS, a partir deste livro, a abordagem da Toyota para a manufatura ficou conhecida como Lean Production.

No livro Lean Thinking [WJ03], James Womack e Daniel Jones explicam os princípios de Lean Manufacturing, este pode ser resumido como "Uma abordagem sistemática para a identificação e eliminação de desperdícios (atividades sem valor agregado), que busca a perfeição através da melhoria contínua, fazendo os produtos fluir de acordo com a necessidade do cliente (Sistemas Pull)" [Lik04](pág. 7).

Hoje em dia as companhias que conseguiram entender e adaptar a essência de Lean Thinking obtiveram uma melhoria significativa e sustentável de desempenho [Dye00](Prefácio).

\subsubsection{Abordagem}

Conforme apresentado na Seção 2.1.1, o Sistema Toyota de Produção promove um processo que busca aumentar a percepção de valor do produto. Através de melhorias no fluxo do processo, o produto é criado rapidamente, ao mesmo tempo em que se aproxima da necessidade do cliente.

A abordagem Lean começa com uma tentativa consciente de definir precisamente o que o cliente valoriza em um produto. Após a definição, as ações necessárias para a criação do produto são identificadas criando assim, o Mapa de Fluxo de Valor (ver Subseção 2.1.4). As etapas são organizadas de forma a se assemelhar a um fluxo de água, no qual o produto deve percorrer até ser finalizado. Quando o fluxo de desenvolvimento de produtos é rápido, mudanças nas necessidades do cliente podem ser identificadas e atendidas rapidamente. Além disso, os problemas são expostos quase que imediatamente, permitindo que eles possam ser removidos. Essa abordagem exige um ciclo constante de inspeção, adaptação e melhoria.

O Sistema Toyota de Produção pode ser representado pelo modelo da Figura 2.2. Nela é possível observar os dois pilares do TPS: Melhoria contínua e Respeito às pessoas.

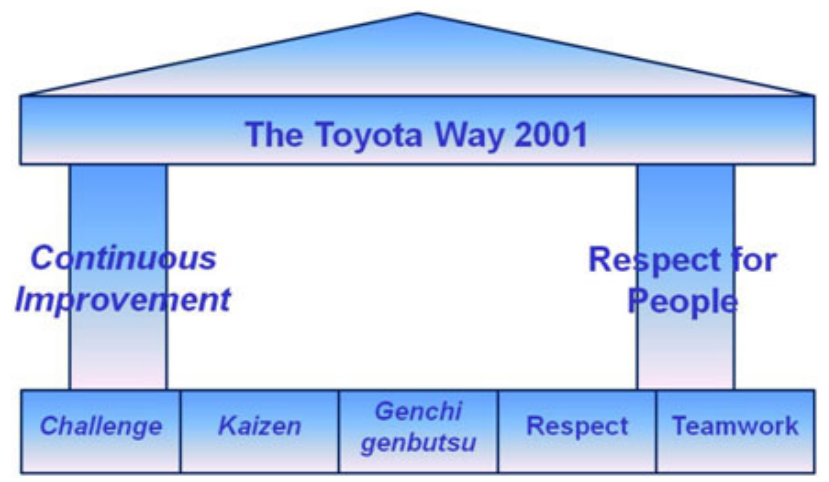

Figura 2.2: Toyota Way 2001.

Fonte: Documento interno da Toyota. As práticas não aparecem no modelo, pois estão um nível abaixo, dando suporte ao Kaizen.

O primeiro pilar, Respeito às pessoas, é um comprometimento amplo, no qual abrange desde as pessoas que trabalham diretamente com a empresa (funcionários, fornecedores, investidores, etc...) 
até a sociedade que se beneficia dos produtos vendidos. Na Figura 2.2, é possível observar suas duas subcategorias [LH07]:

- Respeito: "Nós respeitamos as outras pessoas, e nos esforçamos para entender um ao outro, nos responsabilizamos e fazemos o melhor possível para construir um respeito mútuo";

- Trabalho em equipe: "Nós estimulamos o crescimento profissional e pessoal, e compartilhamos as oportunidades de desenvolvimento, maximizando o desempenho individual e da equipe".

A Melhoria Contínua é o segundo pilar e pode ser definido como "Nós nunca estamos satisfeitos com o que temos hoje e sempre queremos melhorar nosso negócio através de nossas ideias e nossos esforços". Esse pilar possui três subcategorias que completam o modelo da Figura 2.2 [LH07]:

- Desafio: "Nós construímos uma visão de longo prazo, e aceitamos desafios com coragem e criatividade para realizarmos os nossos ideais";

- Kaizen: "Nós melhoramos continuamente nosso negócio, sempre buscando inovação e evolução";

- Genchi Genbutsu: "Nós praticamos Genchi Genbutsu - acreditamos que ir ao local do problema para observá-lo pessoalmente, é a melhor forma de conseguir consenso, tomar decisões corretas e atingir o objetivo rapidamente".

Esses dois pilares, serão explicados a seguir através de 14 princípios que captam a essência do Sistema de Produção da Toyota.

\subsubsection{Princípios}

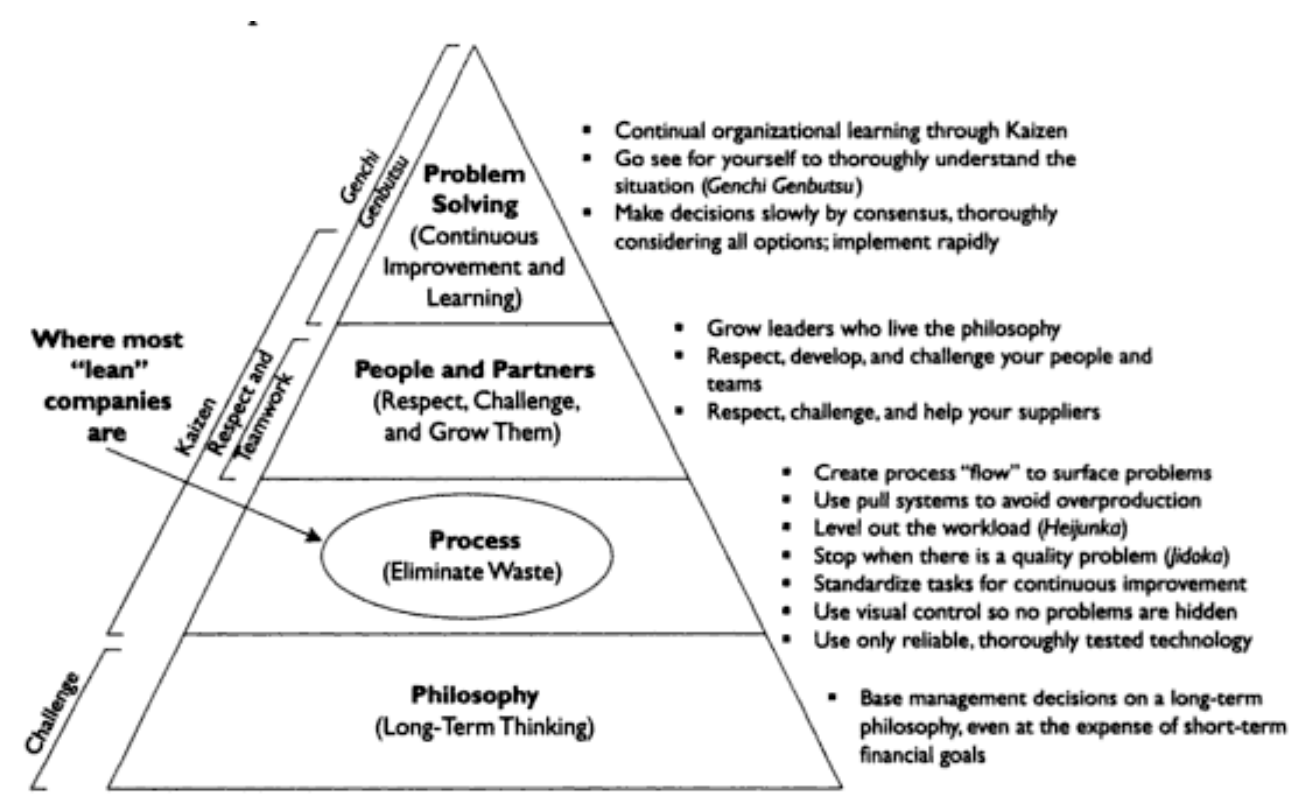

Figura 2.3: Relação entre os princípios de Liker e do documento Toyota Way. Fonte: Toyota Way [Lik04] 
A Figura 2.3 mostra como os 12 princípios que guiam o Sistema Toyota de Produção se relacionam com o modelo da Figura 2.2.

A seguir, será apresentada uma visão ampla dos 12 princípios propostos por Liker [Lik04]. Leitores interessados em se aprofundar no assunto poderão seguir as referências que sugerimos no decorrer do texto.

\section{Baseie as decisões administrativas em uma filosofia de longo prazo, mesmo que elas estejam em detrimento com as metas financeiras de curto prazo}

No Sistema Toyota de Produção, a filosofia de longo prazo é a base para todos os outros princípios. A filosofia consiste em criar valor para os clientes, fornecedores e sociedade como um todo. Essa visão leva a uma abordagem de longo prazo para a construção de uma organização que aprende, que se adapta a mudanças e sobrevive como uma organização produtiva. Sem essa filosofia, nenhum dos investimentos em aprendizado e melhoria contínua seria possível [Lik04].

\section{Crie um fluxo de processo contínuo para trazer os problemas à tona}

Em Lean, a ideia de fluxo sugere transformar todas as etapas essenciais para a criação de um produto em um fluxo estável e contínuo, sem movimentos desnecessários, sem interrupções e sem filas [WJ03].

A ideia de fluxo está intimamente ligada com a noção de que a diminuição do tempo de transformação de uma matéria prima em produto final resulta em melhor qualidade, custo reduzido e tempo de entrega menor [Lik04].

Segundo Uminger [ML06], a Toyota busca fazer com que o conjunto de todos os processos se assemelhem a uma corrente na qual todos os processos são conectados por algum tipo de informação e um fluxo de matéria prima. A corrente nunca é perfeita, mas quando ela quebra em um determinado ponto, a equipe está treinada para consertá-la, tornando a corrente mais forte.

A Figura 2.4 ilustra a metáfora de um barco navegando em um rio com rochas. Nesta analogia, o nível do rio representa o inventário, as rochas no rio são os problemas ou os pontos fracos e o barco representa o processo. Ao diminuir o nível do rio, as rochas grandes começam a aparecer e elas devem ser eliminadas imediatamente, caso contrário o barco bateria nelas.

Analogamente, criar um fluxo de atividades e diminuir o inventário expõe os problemas que demandam soluções imediatas. Essa dinâmica tem sido um ponto central para a abordagem de melhoria contínua da Toyota [LV09].

\section{Use Sistemas Pull para evitar a superprodução}

Em termos simples, um sistema utiliza a abordagem Push quando o produtor produz serviços ou produtos baseando-se na previsão de demanda do cliente. Um sistema utiliza a abordagem 


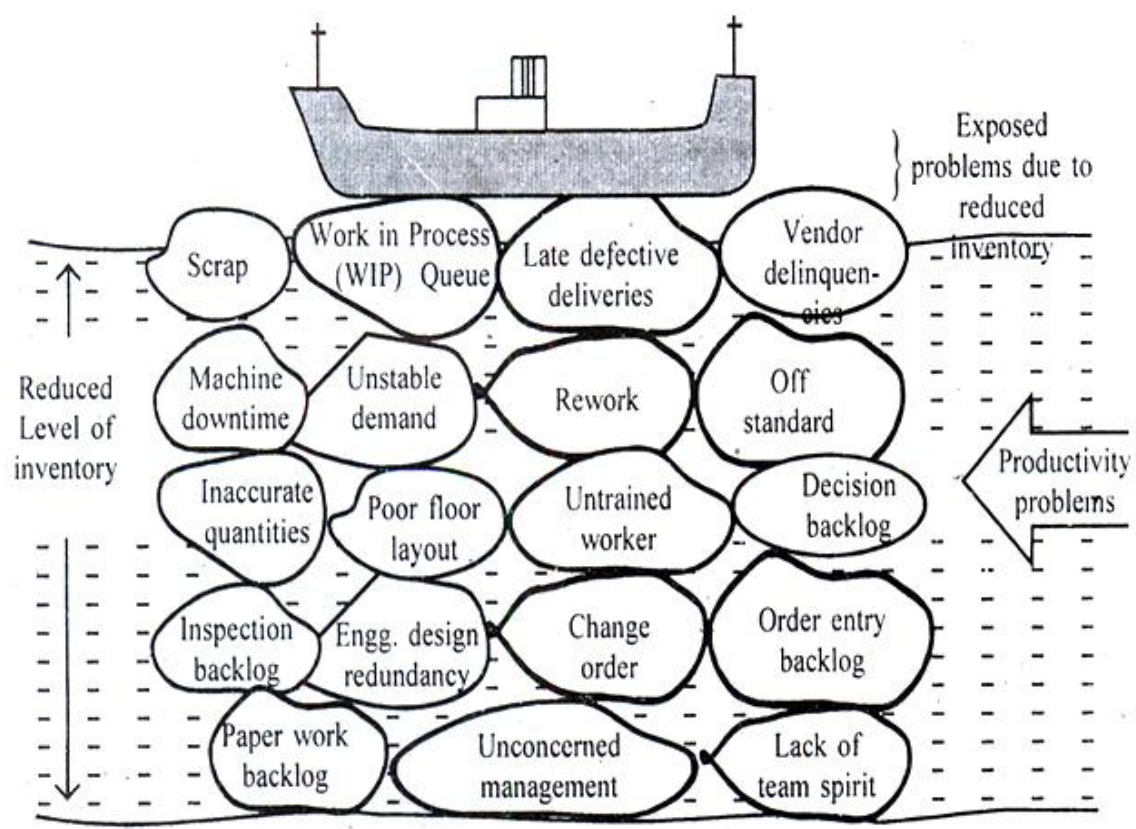

Figura 2.4: Analogia do barco andando em um rio com rochas.

Fonte:http://www.transtutors. com/homework-help/Industrial+Management/Just+in+Time+Production+System/ analogy-to-jit-aspx/

Pull quando o produtor não produz nenhum serviço ou produto até que um pedido seja feito pelo cliente [WJ03].

A maior parte dos departamentos que utilizam Sistemas Push tentam minimizar a quantidade de vezes que a configuração (setup) necessária para a máquina produzir produtos diferentes é modificada. Como resultado, um departamento tenta fazer o maior volume possível de um determinado produto antes de fazer alguma mudança na configuração da máquina. Para que todos os departamentos estejam sempre trabalhando, existe um buffer de inventário entre cada departamento. Isso possibilita que departamentos possam trabalhar independente de um planejamento, entretanto isso também faz com que o volume do buffer dos inventários seja aumentando sem um controle real, gerando superprodução de inventário ou produtos desnecessários [Lik04].

Para evitar a superprodução, Ohno utilizou em suas fábricas pequenas "lojas de abastecimento" para controlar o inventário [Ohn88]. O funcionamento é similar ao de um mercado, quando o cliente tira um produto da loja, o produto é reposto. Se um determinado produto não é retirado da loja pelo cliente, não são adicionado novos produtos do mesmo. O resultado desse modo de operação é um sistema em que não existe produção de itens além da quantidade existente na prateleira e existe uma conexão direta entre o que o cliente deseja e o que a empresa produz.

Entretanto, as fábricas podem ser grandes e espalhadas e os fornecedores podem estar distantes. Para sinalizar quando uma linha de montagem utilizou determinada peça e quando 
ela necessita mais da mesma, Ohno criou sinalizadores simples: cartões, caixas e carrinhos que foram chamados de kanban [Lik04]. A figura 2.5 mostra um cartão kanban da Toyota.

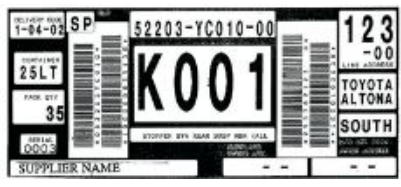

Figura 2.5: Exemplo de um cartão kanban da Toyota.

Fonte: http://www2.toyota.co.jp/en/vision/production_system

\section{Heijunka}

Heijunka é o nivelamento do tipo e quantidade de produção durante um período fixo de tempo. Usando o Heijunka, a produção atende de forma eficiente a demanda do cliente, evitando lotes grandes, o que resulta em um mínimo de inventário, custo, mão de obra e tempo necessário para a criação do produto [MS03].

O Heinjunka é fundamental para a criação de um sistema de produção Lean, pois ele é a chave para a estabilidade [Jon06, Lik04]. Usar o Heijunka traz grandes benefícios para a produção, ela fornece a habilidade de planejar cada detalhe da produção, padronizar as práticas de trabalho e evitar que as pessoas adivinhem no que devem trabalhar em seguida [Jon06].

O nivelamento é feito seguindo a velocidade do departamento mais lento. Ohno utiliza a metáfora da lebre e da tartaruga afirmando que a tartaruga causa menos desperdício e é preferível do que a lebre que avança rapidamente, mas ocasionalmente para para descansar. O TPS só pode ser alcançado quanto todos os trabalhadores se tornam a tartaruga [Ohn88].

5. Construa uma cultura de parar e resolver os problemas, para obter qualidade na primeira tentativa

O Jidoka, automação com um toque humano, é um dos pilares do TPS. Através desse princípio, o trabalho é organizado de forma que qualquer anormalidade é detectada imediatamente, fazendo com que o trabalho pare até que a causa do problema seja tratada. No contexto da produção, Jidoka significa não permitir que peças defeituosas passem de uma estação para outra.

A manufatura Lean aumenta dramaticamente a importância de construir corretamente na primeira vez. Com seus baixos níveis de inventário, não existe buffer para retroceder caso exista um problema da qualidade [Lik04]. Para prevenir que erros ocorram, em cada estação a Toyota utiliza o poka-yoke, instrumentos que tornam quase impossível que um operador erre. Cada instrumento poka-yoke possui seu próprio modelo que resume o problema a ser tratado. Por exemplo, para garantir que o montador utilize três parafusos, os pacotes são embalados em grupos de três parafusos. Esse pacote é um instrumento poka-yoke.

Mesmo com o poka-yoke, erros podem ocorrer. Quando erros ocorrem, os funcionários são instruídos a puxar uma corda que acenda bandeiras ou luzes para sinalizar que é necessário ajuda 
para resolver o problema. Este sistema de sinalização é conhecido como andon, mostrado na figura 2.6.

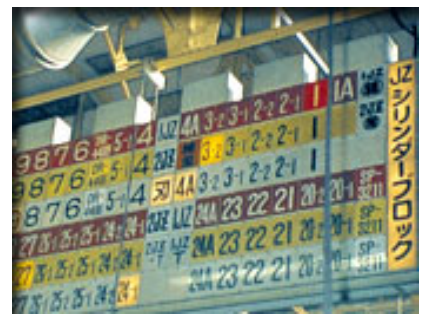

Figura 2.6: Andon quadro que sinaliza qualquer anormalidade.

Fonte: http://www2.toyota.co.jp/en/vision/production_system

\section{Tarefas padronizadas são a base para a melhoria contínua e capacitação dos fun- cionários}

Segundo Ford, a padronização de tarefas é necessária, pois, ela serve como referência para futuras melhorias. Embora uma crença comum na padronização de tarefas seja a de que ela é a busca científica de encontrar a melhor forma de fazer uma determinada tarefa [Lik04], a padronização não deve ser vista como objetivo final, e sim, como uma base para futuras melhorias [ML06].

No livro Kaizen [Ima86], Imai explica que é impossível melhorar qualquer tipo de processo até que ele seja padronizado, pois se o processo possui muita variância, qualquer melhoria é percebida como mais uma variação que ocasionalmente ocorre, sendo ignorada na maioria das

vezes. É necessário primeiro padronizar e estabilizar o processo para que melhorias contínuas possam ser realizadas.

Para um operador de produção na Toyota, o trabalho padronizado compreende três elementos básicos:

- Tempo: prazo exigido pelo cliente e restrição de tempo para capacidade de processamento;

- Sequência: determinação da melhor sequência para a produção de um produto ou serviço;

- Inventário: quantidade necessária de inventário para realizar a tarefa.

A partir desses três elementos, o operador possui os elementos básicos para realizar a tarefa, identificar problemas e fazer melhorias utilizando o ciclo PDCA (Plan-Do-Check-Act) [Lik04].

Para melhorar a aceitação da equipe sobre tarefas padronizadas, as pessoas envolvidas no trabalho devem ser responsáveis por planejar e construir seus próprios procedimentos de trabalhos. Esses devem ser simples e práticos para que possam ser incorporado facilmente no dia-a-dia [Lik04]. 
A Figura 2.7 mostra um exemplo de uma linha de montagem da Toyota, chamada de Fixed Position Stop System. Nela é possível observar os elementos básicos de um trabalho padronizado. Quando o trabalhador percebe algum problema na produção, ele notifica o seu supervisor puxando uma corda que ilumina o quadro andon. Ao perceber o problema, o supervisor vai rapidamente a estação que está com problema e começa um processo de diagnóstico e solução do problema. A produção segue normalmente se o problema puder ser sanado em menos de um minuto. Se não, é interrompida até que o problema seja resolvido [NS09].

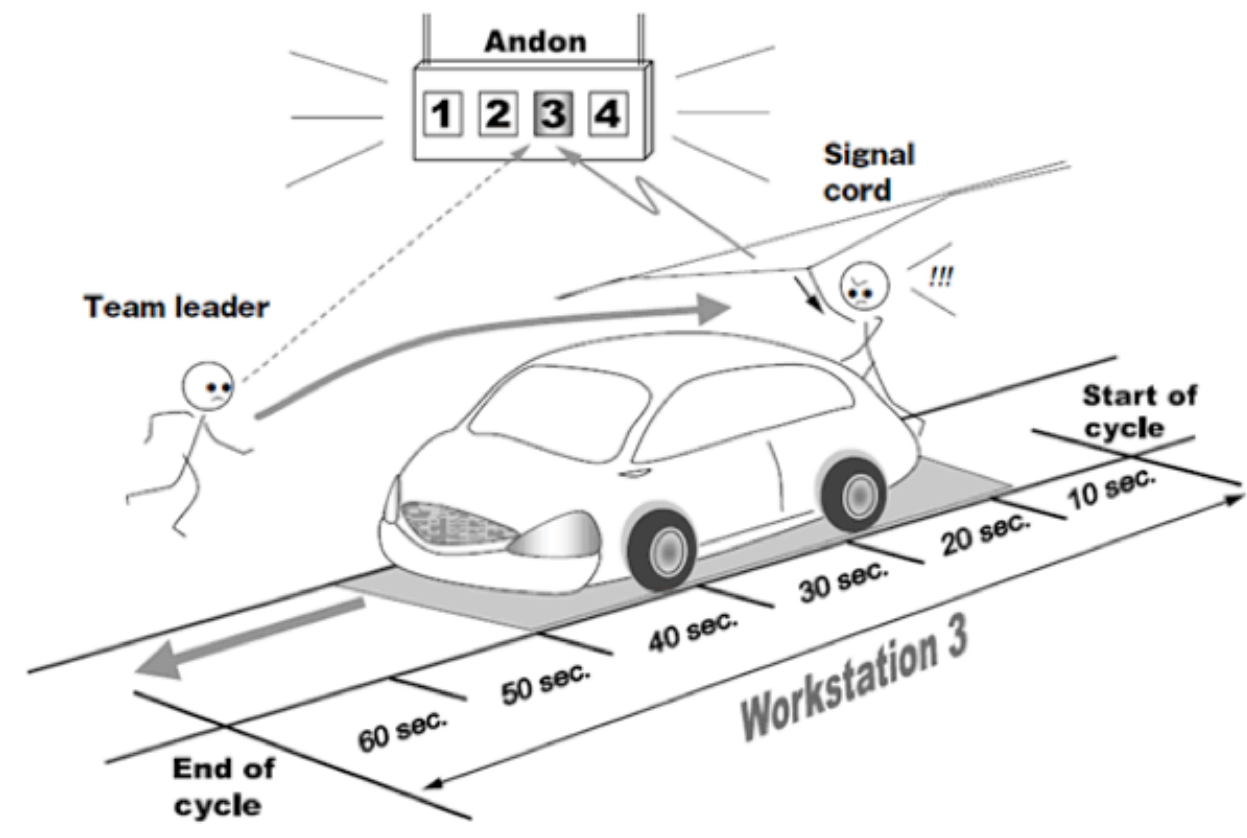

Figura 2.7: Fixed Position Stop System.Fonte: http://www.lean.org/shook/ColumnArchive.cfm?y=2009\#Col1321

\section{Use controle visual para que nenhum problema fique oculto}

Controle visual é qualquer dispositivo de comunicação que informa rapidamente como o trabalho deve ser feito e se ele está desviando do padrão. No sentido mais amplo, controle visual refere-se à concepção de informações just-in-time necessárias para assegurar uma rápida e boa execução das operações e processos. Um bom controle visual não necessita de explicações para ser entendido, pois o significado é imediatamente claro.

O controle visual também pode ser utilizado para melhorar o fluxo. Diversas ferramentas associadas com a produção lean são controles visuais utilizados para tornar visível qualquer desvio do padrão e facilitar o fluxo [Lik04]. Os exemplos dessas ferramentas incluem o kanban e andon, que serão tratados na Subseção 2.1.4.

Os melhores indicadores visuais são os que estão próximo ao local de trabalho, pois através de indicadores visuais e sonoros as pessoas podem ser avisadas imediatamente que um problema está ocorrendo. Um bom sistema de controle visual aumenta a produtividade, reduz os defeitos 
e erros, ajuda a cumprir os prazos de entrega, facilita a comunicação, melhora a segurança, reduz os custos e geralmente ajuda o trabalhador a ter um controle melhor sobre o ambiente de trabalho [Lik04].

8. Use somente tecnologia confiável e completamente testada que atenda as necessidades dos funcionários e dos processos

$\mathrm{Na}$ Toyota, novas tecnologias só são introduzidas após terem sido testadas através de experimentações. Essas experimentações não excluem tecnologias novas ou revolucionárias, isso apenas significa que as tecnologias são rigorosamente testadas para avaliar se elas realmente agregam valor ao processo [Lik04].

Antes da adoção da tecnologia, a Toyota analisa o impacto dela nos seus processos, a tecnologia só é aceita quando o seu uso agrega valor ao processo e ela não está em conflito com a filosofia e princípios operacionais da empresa.

Quando uma nova tecnologia é aceita, ela é adaptada para apoiar o fluxo contínuo no processo e ajudar os trabalhadores a melhorar seu desempenho. Após essa adaptação, a Toyota coloca rapidamente a nova tecnologia em produção. Devido a esse rigoroso processo, a implementação da nova tecnologia geralmente acontece suavemente, sem resistência dos funcionários [Lik04].

\section{Desenvolva líderes que compreendam completamente o trabalho e que sigam a filosofia, ensinando-a a outros}

Na história da Toyota, os principais líderes foram encontrados na própria empresa. Embora todos os líderes possuíssem perfis diferentes, nenhum deles desviou dos princípios básicos do TPS. Ao contrário da maioria das empresas, em que os líderes são trocados frequentemente por pessoas externas a empresa, na Toyota isso não ocorre, pois os líderes precisam entender profundamente a cultura da Toyota no dia-a-dia. Seguindo o genchi genbutsu (Princípio 12) os líderes precisam demonstrar a habilidade de entender como o o trabalho é realizado, pois uma impressão superficial da situação leva a decisões e lideranças ineficientes.

A principal lição que a filosofia da Toyota passa é de que a cultura deve apoiar as pessoas fazendo o trabalho. Segundo Convis [Lik04], os trabalhadores irão executar qualquer trabalho que os seus superiores peçam. Portanto, quando os líderes são consistentes nas prioridades, os trabalhadores aprendem o que é realmente importante e o que não é. As prioridades devem ser muito claras: qualidade, segurança, dedicação e paixão pela profissão.

\section{Desenvolva pessoas e equipes excepcionais que sigam a filosofia da companhia}

Quando uma pessoa é contratada pela Toyota, ela passa por uma orientação detalhada de todo o processo e então é enviada para o seu local de trabalho, no qual será rigorosamente ensinada como realizar o seu trabalho. O processo de aprendizado é constante, envolvendo aulas, oportunidades de participar de treinamentos e workshops nos quais exercita o entendimento da filosofia da empresa. 
Embora o trabalho em equipe seja crítico no desenvolvimento de um produto, possuir pessoas trabalhando em grupo não compensa a falta de habilidade de um trabalhador ou do entendimento da filosofia da empresa.

Pessoas excelentes são necessárias para a criação de equipes excepcionais. Ao desenvolver o trabalho em equipe como um pilar da companhia, a Toyota confia que cada funcionário irá fazer o melhor possível para que a companhia obtenha sucesso, criando novas ideias, oportunidades e soluções [id01].

\section{Respeite a sua rede de parceiros e de fornecedores desafiando-os e ajudando-os a} melhorar

A indústria de fornecedores constantemente relata que a Toyota é o melhor cliente, e também o mais difícil. No caso da Toyota, a palavra difícil significa que a empresa possui padrões de alta qualidade e espera que todos os seus parceiros também possuam. A Toyota trabalha para que haja benefícios mútuos durante as negociações, com respeito mútuo e cooperações com seus parceiros [Sit].

Na perspectiva da Toyota, possuir altas expectativas dos seus parceiros e tratá-los justamente, ensinando-os a melhorarem é um sinal de grande respeito. Existem diversos métodos que a Toyota utiliza para ensinar e aprender com seus fornecedores, na maioria dos casos é utilizando o genchi genbutsu, grupos de estudos voluntários e eventualmente aulas.

\section{Veja por si mesmo para compreender completamente a situação}

Genchi genbutsu significa observar profundamente a situação. Para os líderes da Toyota, não é possível ter certeza que um problema foi completamente compreendido sem que ele tenha sido observado pessoalmente. Para os líderes da Toyota é inaceitável basear-se apenas em relatórios, pois dessa forma é possível que apenas uma impressão superficial do problema seja compreendida [Lik04].

Segundo Tadashi Yamashina [Lik04], genchi genbutsu é mais do que ir até o problema e observá-lo. Para que o genchi genbutstu seja aproveitado ao máximo, é necessário que as pessoas entendam profundamente os conceitos de fluxo e tarefas padronizadas. Além disso, é necessário que as pessoas sejam capazes de avaliar e analisar a situação, entender como chegar na causa raiz do problema e comunicar de forma eficiente com as outras pessoas.

13. Tome decisões lentamente por consenso, considerando todas as opções e implementeas com rapidez (nemawashi)

Para a Toyota, o modo como você chega a uma decisão é tão importante quanto a qualidade da sua decisão. O segredo para as implementações suaves e quase perfeitas de suas iniciativas deve-se a um planejamento inicial cuidadoso e detalhado [Lik04].

Uma tomada de decisão inclui cinco elementos principais [Lik04]:

(a) Descobrir o que está acontecendo utilizando o genchi genbutsu; 
(b) Entender as causas raízes, através da técnica de cinco porquês (ver Subseção 2.1.4);

(c) Considerar as soluções alternativas e desenvolver uma justificativa detalhada para a solução preferida (ver Subseção 2.1.4);

(d) Construir consenso dentro da equipe;

(e) Usar meios de comunicação eficientes para cada elemento acima, preferencialmente utilizando o relatório A3 (ver Subseção 2.1.4).

Durante a tomada de decisão, uma extensa coleta e análise de dados é obtida, fornecendo os seguintes benefícios [Lik04]:

- Descoberta de fatos que se não considerados, poderiam levar a um problema posterior;

- Todas as pessoas envolvidas apóiam a decisão, portanto, é inexistente qualquer resistência durante o trabalho de implementação;

- Aprendizado é obtido antes de um produto ser planejado ou implementado.

\section{Torne-se uma organização que aprende através da reflexão e da melhoria contínua}

Segundo Senge [Sen06], uma organização que aprende é um local no qual:

- as pessoas expandem, continuamente, a sua capacidade de criar os resultados que desejam;

- padrões de comportamentos novos e abrangentes são estimulados;

- a aspiração coletiva ganha liberdade;

- as pessoas, continuamente, exercitam aprender juntas.

Como foi visto no Princípio 6, quando os processos estão estáveis e quando existe um processo que torna visível os problemas e desperdícios, é possível aprender com os próprios erros e fazer melhorias contínuas. Aprender significa possuir a capacidade de construir com a ajuda do seu histórico passado e avançar incrementalmente, ao invés de recomeçar e reinventar todo o processo [Lik04].

O núcleo do kaizen e do aprendizado é a atitude das pessoas: uma atitude de auto-reflexão e auto-crítica, com um desejo contínuo de melhorar. O melhor incentivo que uma organização pode oferecer para que as pessoas aprendam é disponibilizar um ambiente no qual os trabalhores pode discutir abertamente os problemas, tomar a responsabilidade e propor contra-medidas para prevenir que os problemas ocorram novamente [Lik04].

O conceito de reflexão (hansei) na Toyota, tem uma profunda ligação com o conceito de reflexão japonês. O hansei é composto por três componentes:

- O indivíduo deve reconhecer que existe um problema - uma lacuna entre as expectativas e realizações - e ser aberto a críticas;

- O indivíduo deve voluntariamente assumir a responsabilidade e se sentir culpado; 
- O indivíduo deve se comprometer em tomar uma ação para melhorar.

Na cultura da Toyota, hansei é considerado essencial para o kaizen. O que motiva o kaizen são os indivíduos que se esforçam para melhorar voluntariamente, baseado na própria motivação. Na Toyota, os trabalhadores não se satisfazem com o modo como o trabalho é realizado, eles colocam objetivos para melhorias e não se satisfazem com nada menos que 100 porcento de sucesso. Um resultado que obteve sucesso não implica que o processo foi realizado com perfeição, sempre existe algo para aprender através da reflexão [LH07].

\subsubsection{Práticas}

Práticas são técnicas utilizadas no dia-a-dia dos membros da equipe. Elas são claras, objetivas e específicas. Uma mudança no contexto ou no objetivo pode transformar rapidamente uma prática boa em uma prática ruim. Por exemplo, na Subseção 2.1.1, foi mostrado que as práticas da produção em massa não eram adequadas à Manufatura Lean, pois as necessidades eram diferentes.

Para que as práticas possam ser adaptadas a outros contextos, deve-se entender quais são suas motivações, benefícios e limitações. A seguir, será apresentada uma visão geral das principais práticas da Manufatura Lean.

\section{Andon}

Andon é um dispositivo de controle visual que informa a situação atual do sistema de produção através de displays iluminados (ver Figuras 2.8 e 2.9), alertando os membros da equipe quando um problema ocorre [Shi89].

Um sistema Andon fornece ao trabalhador a habilidade de parar a produção e pedir assistência assim que um defeito é identificado. Na manufatura, as causas mais comuns para a ativação do Andon são falta de materiais, defeitos, problemas no equipamento e problemas de segurança do trabalhador.

\section{Kanban}

A Manufatura Lean tenta conectar todas suas etapas de desenvolvimento para criar um fluxo contínuo de produção. Quando não é possível conectar as etapas diretamente, utiliza-se o kanban para criar um fluxo contínuo de materiais. O kanban é um cartão que contém informações relevantes sobre o material a ser produzido, como quantidade necessária, especificações técnicas e localização do fornecedor e do trabalhador (cliente) que necessita do produto. Utilizado como um sinalizador, o kanban estabelece conexões diretas entre o fornecedor e cliente, informando a quantidade e o tempo correto para que o produto passe para a etapa posterior [SB99].

A implementação de um sistema kanban tem como objetivo:

- Criar um Sistema Pull, evitando que a superprodução de materiais ocorra;

- Controle visual, mostrando o que está sendo produzido e em qual sequência; 


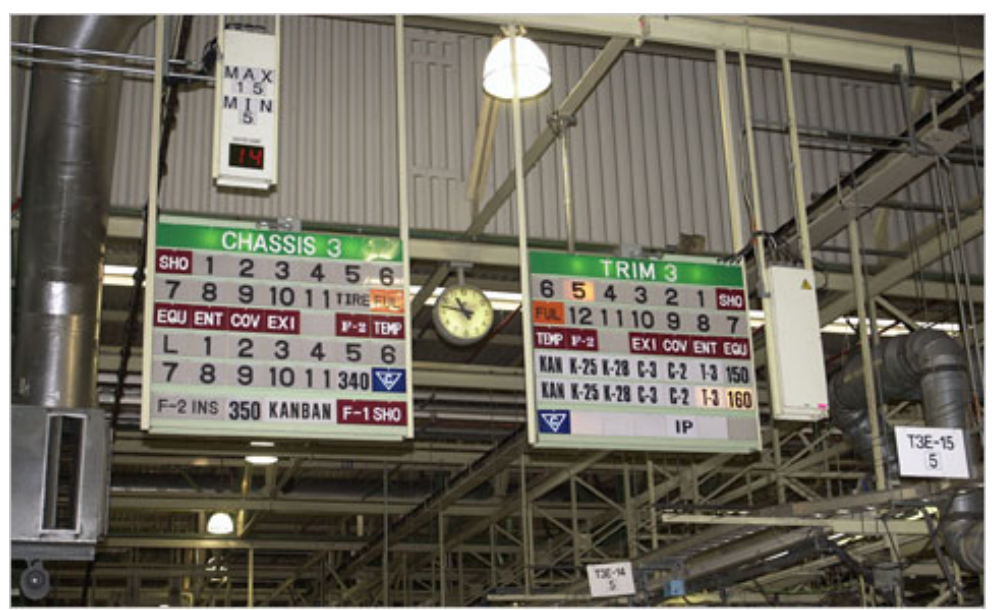

Figura 2.8: Um quadro Andon em uma fábrica da Toyota. O quadro comunica qualquer anormalidade na linha de produção.

Fonte: http://wheels.blogs.nytimes.com/2009/09/04/toyota-quality-control-includes-greensleeves-and-popeye

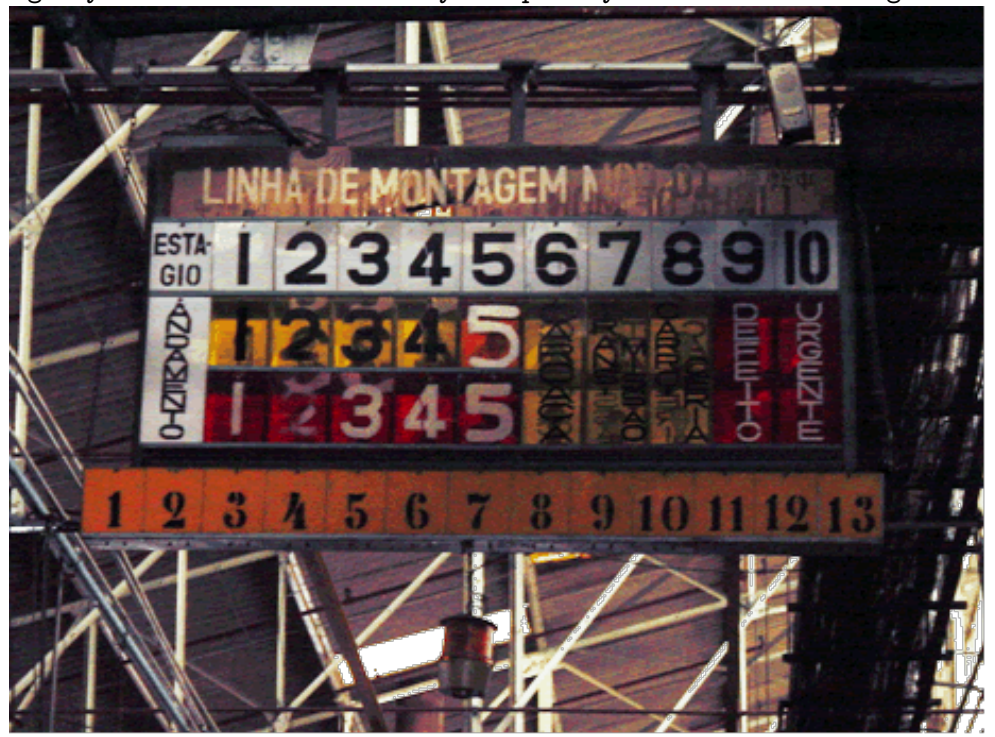

Figura 2.9: Um quadro Andon da Toyota do Brasil. Cada número representa uma área da linha de produção. Quando o trabalhador puxa a corda localizada na sua área de trabalho, o número apropriado acende, sinalizando ao líder da equipe que um dos seus trabalhadores está com problema.

Fonte: http://www.lean.org/shook/ColumnArchive.cfm?y=2009\#Col1166

- Promover melhorias, como cada cartão representa uma determinada quantidade de inventário no sistema, quando um cartão é retirado de circulação, a empresa é forçada a melhorar seus processos, reduzindo o tempo de preparação e o tamanho dos lotes para que essa mudança seja viável.

\section{Cinco Porquês}

Cinco porquês(5-Whys) é um processo simples utilizado para descobrir as possíveis causas do problema. Ao utilizar a pergunta "por quê?" em cada etapa da solução, descobre-se o motivo da ocorrência de determinado problema até que se chegue ao problema-raiz. O nome da técnica Cinco Porquês é metafórico. O processo de perguntar "por quê?" deve continuar até chegar na raiz do 
problema [Sch98].

Através da identificação da causa raiz do problema, ações efetivas possam ser desenvolvidas e implementadas [WJ03]. Segundo Ohno [Lik04], uma verdadeira solução para o problema acontece apenas quando a causa raíz do problema é tratada.

Um exemplo clássico do uso dessa técnica é apresentado na tabela 2.1.

\begin{tabular}{|c|c|c|}
\hline & Problema & Ação para corrigir o problema \\
\hline Por quê? & $\begin{array}{l}\text { Existe uma poça de óleo no chão da } \\
\text { fábrica. }\end{array}$ & Limpe o óleo. \\
\hline Por quê? & Porque a máquina está vazando óleo. & Conserte a máquina. \\
\hline Por quê? & $\begin{array}{l}\text { Porque o material de vedação se de- } \\
\text { teriorou. }\end{array}$ & Troque o material de vedação. \\
\hline Por quê? & $\begin{array}{l}\text { Porque o material de vedação com- } \\
\text { prado era de baixa qualidade. }\end{array}$ & $\begin{array}{l}\text { Troque as especificações do material } \\
\text { de vedação. }\end{array}$ \\
\hline Por quê? & $\begin{array}{l}\text { Porque um bom acordo (preço) foi } \\
\text { obtido nos material de vedação. }\end{array}$ & Troque as políticas de compra. \\
\hline Por quê? & $\begin{array}{l}\text { Porque a pessoa responsável por } \\
\text { comprar é avaliado na economia de } \\
\text { curto prazo. }\end{array}$ & $\begin{array}{l}\text { Troque a política de avaliação dos } \\
\text { pessoas responsáveis pela compra. }\end{array}$ \\
\hline
\end{tabular}

Tabela 2.1: Análise do problema através do Cinco Porquês.

\section{Set-based design}

Em A Theory of Quantitative Inference Applied to a Mechanical Design Compiler [War89], Ward discute uma abordagem exploratória na qual diversas soluções alternativas para um problema são discutidas e, gradativamente, as alternativas inferiores são eliminadas até que uma solução adequada seja encontrada. Posteriormente, no artigo Toyota's principles of set-based concurrent engineering [SWL99] a abordagem ficou conhecida como Set-based Concurrent Design ou simplesmente, Set-based design. Essa abordagem, contrasta com o desenvolvimento iterativo em que apenas uma alternativa é escolhida e, após diversas iterações, a solução adequada é moldada [LEC95].

Segundo Ward et al. [WLCS95], apesar do Set-based design aparentar ser uma estratégia extremamente ineficiente, a técnica oferece uma grande vantagem competitiva, pois permite que o desenvolvimento de produtos seja mais seguro, rápido, eficiente e barato.

\section{Relatório A3}

O Relatório A3 (A3 report) refere-se a um formato padronizado de comunicação que expressa o processo de solução de um problema em uma folha de papel, geralmente um papel A3. O uso de apenas uma folha para expressar todo o conhecimento faz com que as pessoas refinem seus pensamentos de modo que todas as questões e soluções sejam expostas de forma simples [ML06].

A Figura 2.10 apresenta um modelo de Relatório A3. No lado esquerdo do modelo existem quatro passos utilizados para diagnosticar a causa do problema. Após a causa do problema ser identificada, uma lista de possíveis experimentos é criada para tratá-la. Os experimentos devem 
ser rápidos e econômicos e, como boa prática, devem predizer qual seria o resultado ao utilizá-los. Após a realização de diversos experimentos rápidos, o entendimento sobre o sistema é melhorado e deve ser difundido pela empresa. Um resumo de como o sistema se comporta com as contramedidas e um plano para torná-las permanente deve estar presente no Relatório A3 [PP10].

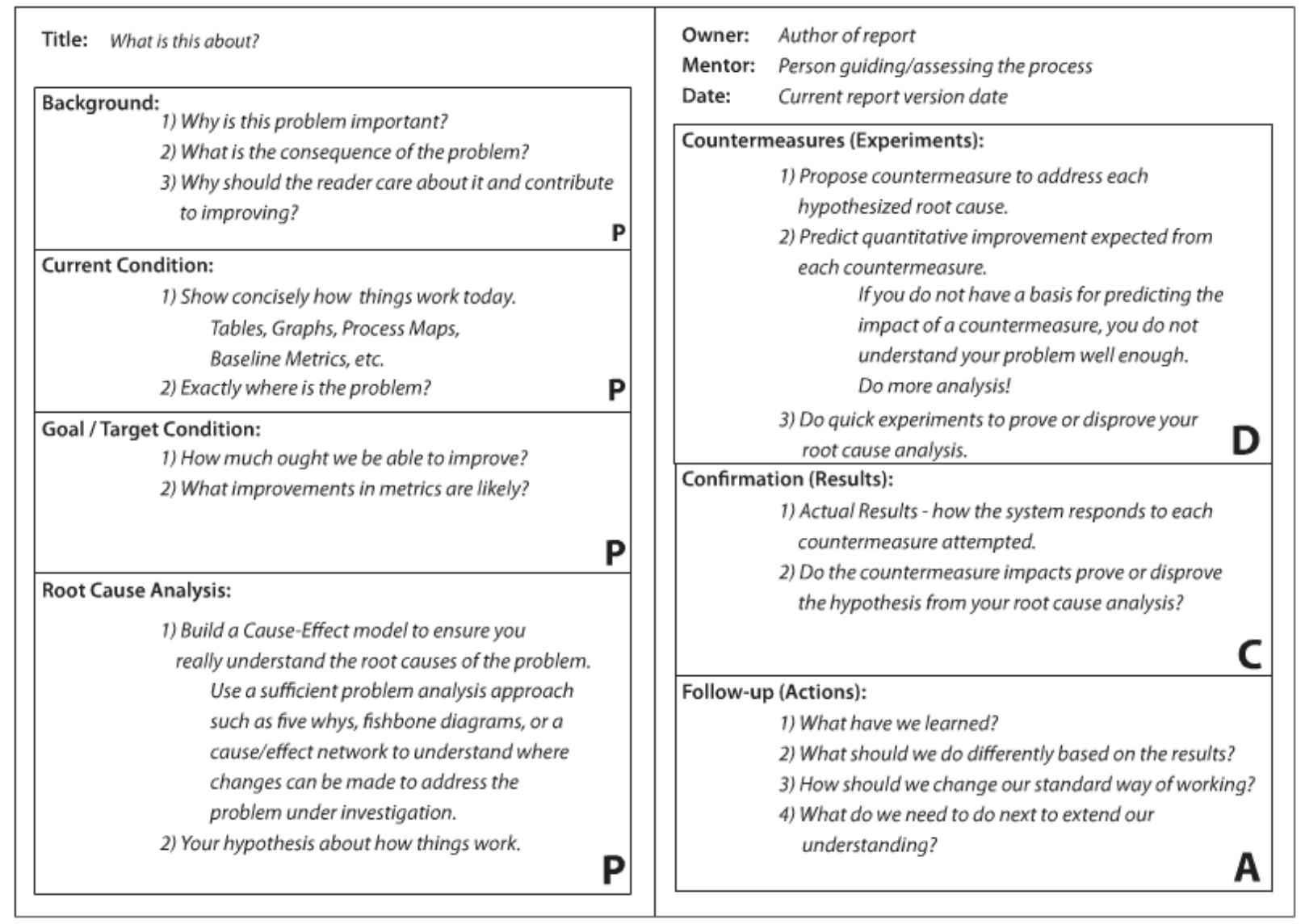

Figura 2.10: Modelo de Relatório A3.

Fonte: Leading Lean Software Development. Mary and Tom Poppendieck. Addisson-Wesley

Um Relatório A3 é considerado satisfatório quando uma pessoa familiar no assunto consegue entendê-lo completamente em dez minutos ou menos. Para que isso ocorra, um relatório deve ser cuidadosamente construído através de gráficos, diagramas, tabelas e sentenças simples e diretas.

\section{Mapa de Fluxo de Valor (Value Stream Map)}

O Mapa de Fluxo de Valor é uma ferramenta que auxilia a identificar oportunidades de melhorias em uma organização. Através de uma visão geral do processo, um diagrama é construído identificando todas as atividades necessárias para a construção do produto. Womack [WJ03] afirma que o objetivo inicial do Mapa de Fluxo de Valor é organizar as atividades em três categorias:

1. Atividades que agregam valor ao produto;

2. Atividades que não agregam valor, mas que são essenciais durante o desenvolvimento do produto; 
3. Atividades que não agregam valor e não são essenciais durante o desenvolvimento do produto.

Após a categorização, as atividades que pertencem ao grupo 3 devem ser totalmente eliminadas. As atividades restantes devem ser organizadas utilizando os conceitos de Sistemas Pull, criando um fluxo de processo que agrega valor continuamente ao produto, ao mesmo tempo que busca a perfeição através de melhorias contínuas.

Segundo Rother [RS03], o Mapa de Fluxo de Valor é uma ferramenta que oferece diversos benefícios, auxiliando a:

- Ter uma visão ampla do processo, permitindo melhorias globais ao invés de melhorias locais;

- Identificar possíveis desperdícios no processo;

- Criar um vocabulário comum sobre o processo de desenvolvimento;

- Mostrar a conexão entre o fluxo de informação e de materiais;

- Criar uma base para o processo de melhoria contínua.

\subsubsection{Conclusão}

Esta subseção apresentou os principais aspectos da Manufatura Lean, descrevendo seus princípios e práticas. A abordagem Lean é uma filosofia que visa aumentar a satisfação do cliente através da criação consistente de valor em todas as etapas de desenvolvimento. Observando os princípios é possível observar quatros aspectos fundamentais no Sistema Toyota de Produção [LH07]:

- A Toyota enxerga a organização como um sistema, em que todas as partes da organização são inter-relacionadas. Isso pode ser observado pelo modelo que a Toyota utiliza para representar o Sistema Toyota de Produção. No modelo da Figura 2.2, utiliza-se uma casa para representar o sistema, qualquer falha na fundação ou pilar torna a construção frágil. Por exemplo, se a visão de longo prazo for removida, apenas as práticas que possuem efeito imediato serão implementadas. Além disso, não haverá investimento para o desenvolvimento das pessoas e como consequência, não será possível ter uma organização que busca a melhoria contínua. Por outro lado, se removermos as práticas, será mais difícil identificar os problemas, tornando menos provável que as pessoas desenvolvam habilidades para resolver problemas;

- As práticas de Lean devem ser utilizadas para ajudar as pessoas a melhorar continuamente. Esse fato pode ser facilmente observado através do modelo da Figura 2.2. As práticas de Lean estão um nível abaixo da fundação da Toyota, como kaizen;

- Um dos principais objetivos do desenvolvimento é o aprendizado. Na Toyota, os projetos não são apenas avaliados pelo resultado obtido, mas também, pelo aprendizado que foi obtido durante o processo de desenvolvimento;

- Os principais valores para a empresa são a Melhoria Contínua e as Pessoas. 
Uma das principais razões para o sucesso da Toyota é a cultura que permeia toda a empresa [LH07]. Dessa forma, a adoção da abordagem Lean pode implicar em uma mudança radical na mentalidade dos valores e princípios da empresa. Apenas a introdução de algumas ferramentas não significará sucesso na implementação.

\subsection{Teoria das Restrições}

A Teoria das Restrições é uma filosofia de negócio que busca alcançar o objetivo de um sistema através da melhoria da capacidade produtiva da organização. Nos seus 30 anos de existência, a Teoria das Restrições evoluiu rapidamente em termos de metodologia [CS98,Det97] e aplicações [BM98]. Um dos pontos centrais a essa filosofia de gerenciamento é o pressuposto que qualquer organização, por mais complexa que seja, é limitada pelo desempenho de um ou poucos elementos.

A Teoria das Restrições promove um processo que busca aumentar a capacidade produtiva da organização através de melhorias no fluxo do processo. Uma tendência natural para melhorar o desempenho de um sistema é realizar melhorias locais. O senso comum diz que se as partes de um sistema forem otimizadas, o sistema todo também o será. A Teoria das Restrições parte do princípio de que essa premissa é inválida. Segundo Goldratt, "bons resultados globais não são iguais à soma de bons resultados locais", para que um processo seja melhorado é necessário identificar e melhorar os pontos de alavancagem, locais nos quais pequenas melhorias tem um grande impacto na organização [Mea06].

Para identificar os pontos de alavancagem é necessário enxergar a organização como um todo, analisando como as partes de uma organização interagem entre si. A Teoria das Restrições fornece um conjunto de ferramentas, conhecidas como Processo de Raciocínio, que auxiliam na criação de uma visão global do sistema, permitindo que melhorias possam ser implementadas. Devido a suas características, esse conjunto de ferramentas é particularmente eficaz para resolver problemas complexos, e.g., problemas em que existem uma grande dependência entre decisões passadas e ações externas, e problemas que ocorrem devido a má coordenação entre as partes envolvidas.

Nesta seção será apresentada uma visão ampla sobre a evolução da Teoria das Restrições e uma descrição de seus princípios e práticas. O objetivo é apresentar de forma sucinta o processo utilizado pela Teoria das Restrições para realizar melhorias contínuas em uma organização.

\subsubsection{Histórico}

O desenvolvimento da Teoria das Restrições (TOC) teve início quando um vizinho de Goldratt pediu assistência no desenvolvimento de um software que melhorasse a produção de sua fábrica de gaiolas para aves [Byl83]. Após o uso do software desenvolvido por Goldratt, a fábrica triplicou a produção em um curto período de tempo ${ }^{3}$.

Em 1980, na conferência internacional $\mathrm{APICS}^{4}$, Goldratt apresentou sua solução: um software de escalonamento conhecido como Optimized Production Timetables, posteriormente renomeado

\footnotetext{
${ }^{3}$ Os relatos de melhoras citados são baseados na bibliografia citada.

${ }^{4}$ Advancing Productivity, Innovation, and Competitive Success (APICS), organização norte-americana sem fins lucrativos com o propósito de definir e difundir os conceitos relacionados com a gestão de produção e de materiais. Para mais informações consulte o site http://www.apics.org/
} 
para Optimized Production Technology [Gol80]. A solução Optimized Production Timetables evoluiu de um sistema kanban computadorizado para uma tentativa de automatização da técnica tamborpulmão-corda [Gol87].

A solução de Goldratt partia do princípio que para que uma fábrica se aproxime da capacidade produtiva máxima, apenas a máquina mais lenta deve ser utilizada na capacidade produtiva máxima. As outras máquinas devem produzir apenas o suficiente para que a máquina mais lenta funcione na capacidade máxima. Na época, a solução proposta por Goldratt sofreu uma forte oposição dos gerentes de fábricas, pois a crença era que se todas as máquinas operassem na capacidade produtiva máxima a fábrica produziria na capacidade máxima [GBG94]. Para atenuar a situação, Goldratt escreveu o livro The Goal [GC84], no qual os conceitos utilizados pelo software são gradativamente apresentados durante as situações diárias de uma fábrica.

Após a publicação do livro, Goldratt recebeu diversas cartas que relatavam aplicações dos conceitos nas fábricas. Embora a maior parte das cartas tenham sido relatos de sucesso, algumas cartas apontavam alguns obstáculos durante a implementação dos conceitos. Como forma de responder as principais dificuldades encontradas nas implementações, Goldratt publicou o livro The Race [GFG86] que apresenta um sistema de logística para fluxo de materiais e explicações de como expandir o conceito para outras áreas, como marketing e controle financeiro.

Foi apenas por volta de 1987 [Rah98], após a publicação da revista Theory of Constraints [Gol87], que o termo Teoria das Restrições passou a ser utilizado, representando todos os conceitos apresentados pelos livros The Goal [GC84] e The Race [GFG86].

Com a expansão do uso da Teoria das Restrições novos problemas surgiram. No entanto, a maior parte dos problemas não estava relacionada com a área de produção, eram problemas relacionados com políticas da empresa. Em 1994, Goldratt publicou o livro It's Not Luck [Gol94] que apresentava um roteiro (roadmap) para descobrir soluções para problemas complexos e não estruturados.

Em 1990, na International Jonah Conference, um método para escalonamento e controle de projetos baseado nos conceitos de TOC foi introduzido. Entretanto, apenas em 1997, com o lançamento do livro Critical Chain [Gol97], o método de escalonamento Critical Chain Project Management foi amplamente difundido. Desde a sua re-introdução, muitas referências foram escritas [ER98, Lea99, UU00, Ste01, RBD03, CMS04], porém, a metodologia permaneceu inalterada [WBG07].

\subsubsection{Princípios}

No programa de auto-aprendizado SLP7 - Managing People [Gol02] e Necessary and Sufficient - Unit 2 [Gol03], Goldratt expõe os três princípios básicos da Teoria das Restrições: Simplicidade Inerente, Harmonia e Respeito. Os dois primeiros princípios derivam diretamente das palavras de Isaac Newton: "a natureza é extremamente simples e harmoniosa em si mesma" ("natura valde simplex et sibi consona"), enquanto o último princípio deriva de uma crença pessoal de Goldratt. 


\section{Simplicidade Inerente}

O primeiro princípio, Simplicidade Inerente ou Convergência, afirma que todo sistema possui uma simplicidade intrínseca que está relacionada ao fato que em tais sistemas seus componentes estão interligados por relações de causa e efeito que convergem, sempre, a poucas causas comuns. Essas poucas causas comuns, que controlam o comportamento de todo o sistema, são definidas como restrições.

\section{Harmonia}

O segundo princípio, Harmonia ou Consistência, faz referência à segunda parte da frase de Newton. Esse princípio estabelece que se duas interpretações estão em contradição, uma ou possivelmente as duas devem estar erradas [Gol08b]. Para ilustrar esta definição, suponha-se que seja solicitado a duas pessoas efetuar a medição da altura de um objeto usando instrumentos diferentes e que cada uma delas informe um número diferente. Considerar que a medida correta corresponde à média das duas medições não faz sentido. Ou uma delas está errada ou ambas estão, ou seja, não existe contradição. O que precisa ser feito é revelar os pressupostos que sustentam a contradição (no caso do exemplo dado, os pressupostos dos métodos utilizados e/ou dos instrumentos de medições) e identificar ao menos um pressuposto falso. Quando este pressuposto falso é identificado e eliminado, a contradição desaparece.

Uma consequência desse princípio é que quando existe uma contradição e o objetivo é comum entre as partes, uma solução em que ambos os lados ganhem é sempre possível. Uma solução que elimine inteiramente o conflito possui o potencial de abrir novas e significativas oportunidades de melhoria [Gol08b].

\section{Respeito}

O terceiro princípio, Respeito, provém de uma crença pessoal de Goldratt no qual as pessoas sempre possuem boas intenções, mesmo quando eles fazem coisas que parecem ser estúpidas [GC84]. Em outras palavras, este princípio estabelece que as pessoas seguem sempre uma lógica que dita os seus comportamentos. Goldratt afirma que as pessoas se comportam de acordo com a forma com que estão sendo avaliadas: "Diga-me como serei avaliado e eu lhe direi como me comportarei" [Gol91]. Em função deste princípio e dos anteriores, decorre que as pessoas são, até certo ponto, previsíveis. Além disso, que os problemas em uma organização não estão nas pessoas em si, mas sim na forma como a organização está estruturada.

\subsubsection{Processo de Raciocínio}

O Processo de Raciocínio é um conjunto de ferramentas lógicas, baseadas em relações de causa e consequência, que foram desenvolvidas para auxiliar uma organização a atingir um processo de melhoria contínua. Segundo Goldratt [Gol94], para que uma organização possua um processo de melhoria contínua, ela deve ser capaz de responder sistematicamente três perguntas fundamentais: O que mudar?, Para o que mudar? e Como causar a mudança?

Durante o início de um processo de melhoria contínua, deve-se identificar quais são os possíveis 
problemas que uma organização possui. No entanto, muitas vezes durante a fase de identificação de problemas, a quantidade de problemas decorrentes de outros é tão alta que torna-se praticamente impossível lidar com todos os problemas ao mesmo tempo. Portanto, o primeiro passo do processo de melhoria contínua deve ser identificar quais problemas devem ser tratados. Para auxiliar nesse primeiro passo, a Teoria das Restrições utiliza-se da Árvore da Realidade Atual.

Um princípio básico do Processo de Raciocínio é que a imensa maioria dos problemas organizacionais são dependentes uns dos outros, existindo entre eles uma forte relação de causa e consequência. O segundo é que qualquer processo de melhoria contínua eficaz deve encontrar os pontos de alavancagem, que são os locais nos quais pequenas melhorias tem um grande impacto na organização [Mea06].

Construída para responder a questão "O que mudar?", a Árvore de Realidade Atual é uma ferramenta que utiliza condições necessárias e suficientes ("se ... então ...") para identificar e descrever as relações de causa e consequência entre os diversos problemas de uma organização. Após a construção da Árvore da Realidade Atual é possível observar de forma clara os principais problemas de uma organização e quais surtiriam maior efeito caso fossem melhorados.

Existem diversas formas para construir a Árvore de Realidade Atual [Sch10], a mais comum é começando com a identificação de uma lista de $\operatorname{sintomas}^{5}$ que estão afetando negativamente a organização (ver Figura 2.11). Com base nos sintomas observados, deve-se identificar as relações de causa e consequência entre eles. Normalmente, nem todos os sintomas observados podem ser relacionados diretamente. Neste caso, adicionam-se passos intermediários para tornar clara a relação de causa e consequência. A Figura 2.12 apresenta os sintomas identificados na Figura 2.11 com suas devidas relações de causa e consequência. O problema-raiz ${ }^{6}$ é a entidade que não possui flechas chegando.

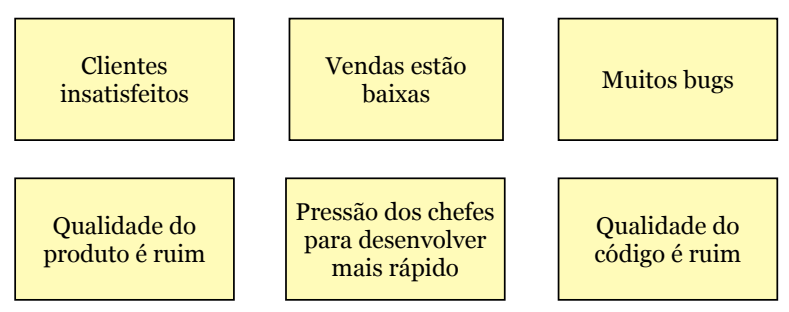

Figura 2.11: Lista de sintomas identificados. Exemplo baseado no caso real descrito por Tom Poppendieck e Henrik Kniberg para Deep Lean 2009 em Stockholm e Agile 2009 em Chicago.

Fonte: http://www.crisp.se/lean/a3-template

Geralmente, o problema-raiz é resultante de algum tipo de suposição errônea. Por exemplo, o problema-raiz da Figura 2.12 resulta da hipótese que adicionar qualidade ao desenvolvimento

\footnotetext{
${ }^{5} \mathrm{Na}$ Teoria das Restrições utiliza-se o termo sintoma ou efeito indesejável ao invés de problemas. Goldratt sugere o uso desses termos, pois segundo ele, a maior parte dos problemas não são problemas, mas sim, consequências de problemas maiores.

${ }^{6} \mathrm{O}$ dicionário TOCICO [SRC07] define problema raiz como um conflito, ou uma suposição errônea que é a origem de $70 \%$ ou mais dos sintomas observados.
} 


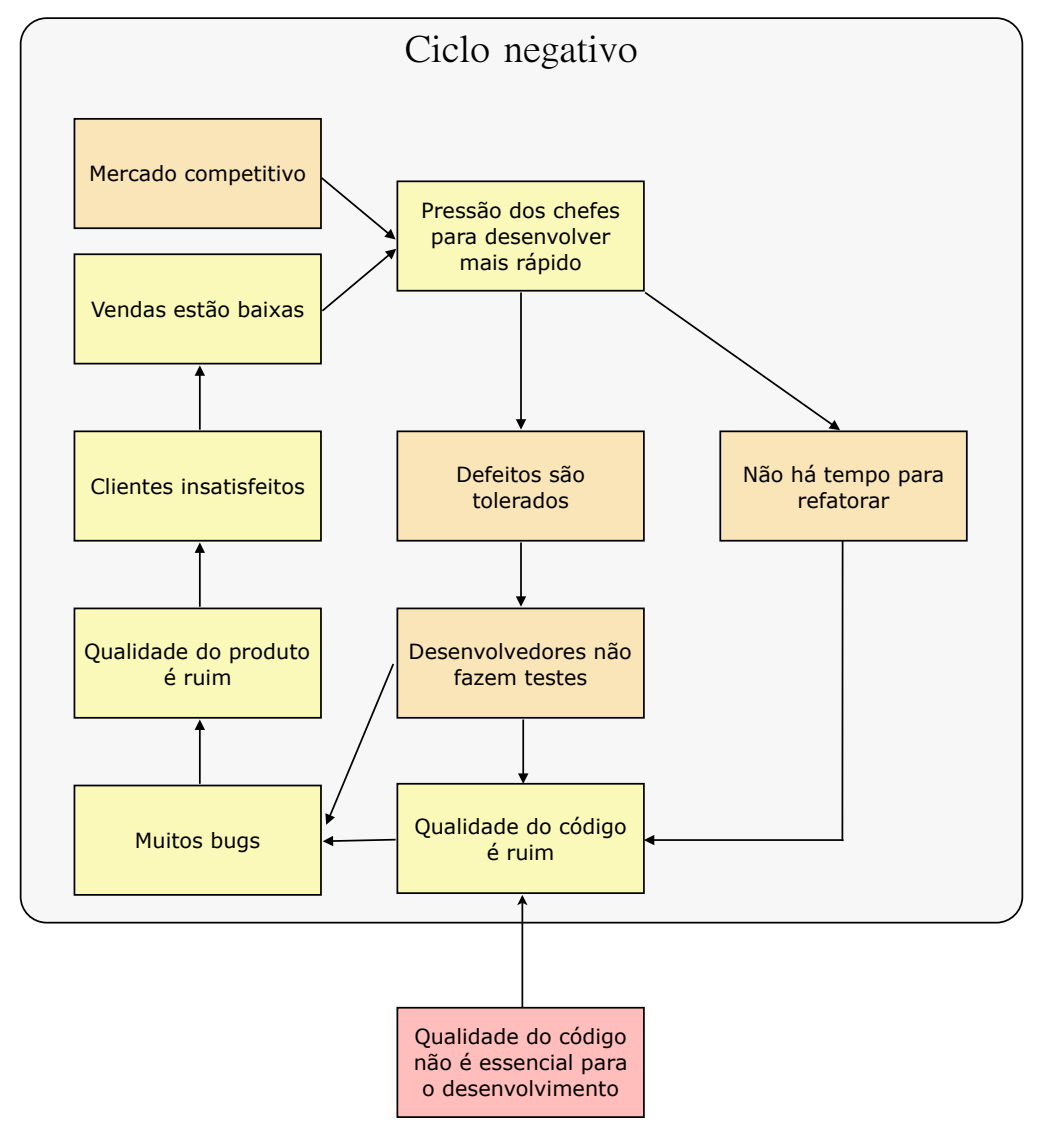

Figura 2.12: Relações de causa e consequência dos sintomas identificados na Figura 2.11. Exemplo baseado no caso real descrito por Tom Poppendieck e Henrik Kniberg para Deep Lean 2009 em Stockholm e Agile 2009 em Chicago. Fonte: http://www.crisp.se/lean/a3-template

torna-o mais lento. Para estruturar e explorar as suposições, a Teoria das Restrições fornece a ferramenta chamada Nuvem $^{7}$.

Para construir a Nuvem, deve-se primeiro identificar qual o objetivo comum do conflito. No exemplo acima o objetivo é aumentar as vendas do produto. A partir da identificação do objetivo, deve-se explorar os pressupostos das hipóteses, identificando ideias para melhorar a situação. A Hipótese(1) será que para que as vendas aumentem é preciso criar mais funcionalidades. Para criar mais funcionalidades, deve-se desenvolver o mais rápido possível, evitando desperdiçar o tempo com tarefas desnecessárias, como melhorar a qualidade do código. A Hipótese(2) é que para as vendas aumentarem é necessário melhorar a qualidade do produto, portanto, deve-se desenvolver agregando qualidade em todas as etapas de desenvolvimento, logo, se importar com qualidade é essencial. A Figura 2.13 mostra uma representação da Nuvem e os pressupostos de cada entidade criada para explorar o problema-raiz da Figura 2.12. Através da Nuvem, é possível identificar que alguns pressupostos da Hipótese(1) são errôneos. Por exemplo, "Se eu não me preocupo com a qualidade, consigo sempre desenvolver mais rápido.", esse pressuposto é errado, pois, ao desenvolver

\footnotetext{
${ }^{7}$ A Nuvem também é conhecida como Diagrama de Dispersão de Nuvem e Diagrama de Resolução de Conflitos
} 
funcionalidades sem se preocupar com a qualidade, acumula-se dívida técnica ${ }^{8}$. Se a dívida crescer o suficiente, eventualmente a equipe de desenvolvimento gastará mais tempo mantendo o sistema do que adicionando novas funcionalidades [McC07]. A partir da identificação da Hipótese errada, deve-se construir uma injeção ${ }^{9}$. No exemplo, a injeção pode ser descrita como "Refatorar o código e fazer testes" para manter a dívida técnica baixa.

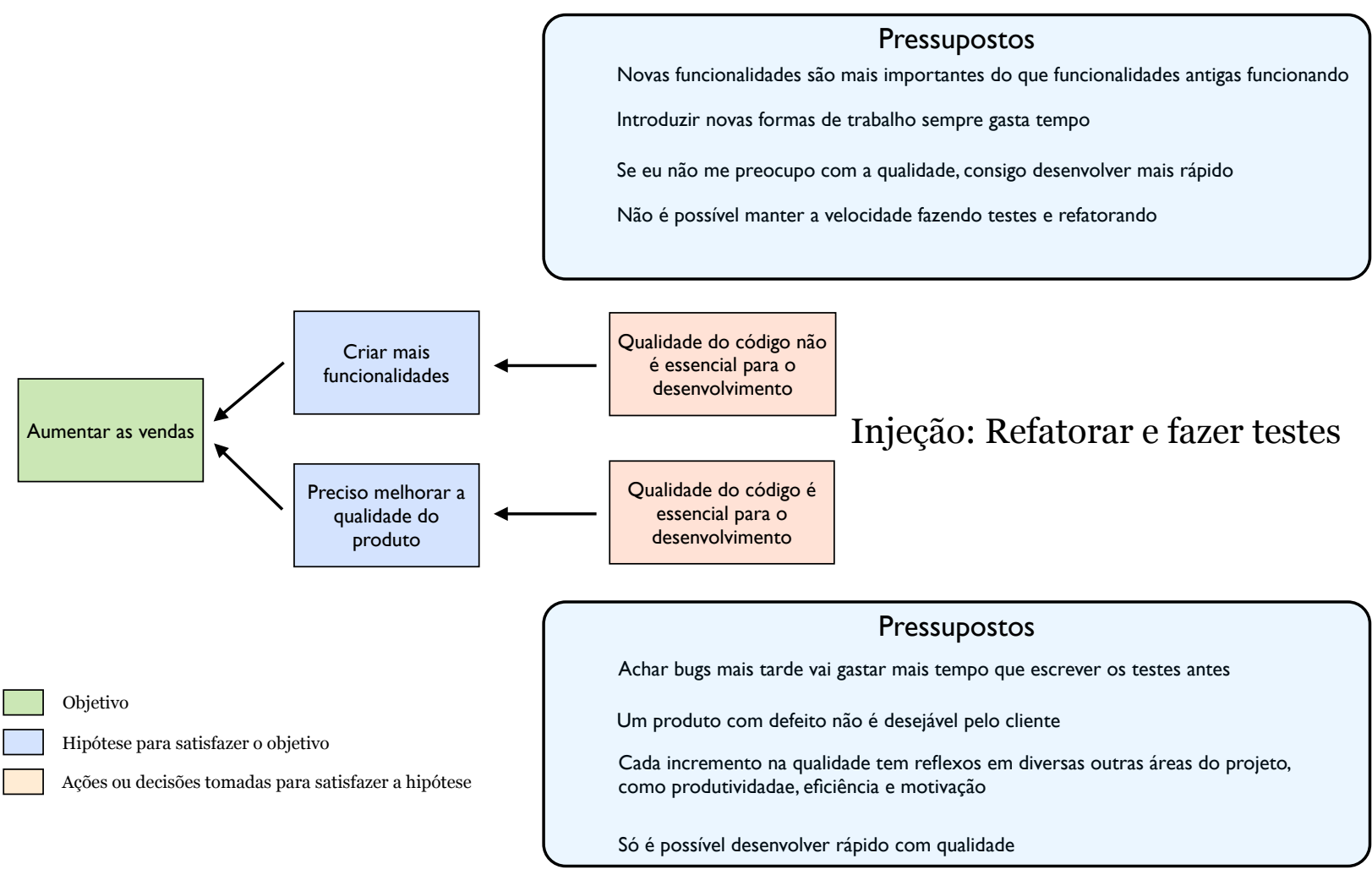

Figura 2.13: Nuvem que representa o conflito e os pressupostos do problema-raiz da Figura 2.12. Exemplo baseado no caso real descrito por Tom Poppendieck e Henrik Kniberg para Deep Lean 2009 em Stockholm e Agile 2009 em Chicago.

Fonte: http://www.crisp.se/lean/a3-template

Após a identificação da injeção, deve-se observar se a situação após a implementação dela será melhor do que a situação atual. Para explorar os benefícios da injeção e identificar os possíveis ramos negativos, a Teoria das Restrições fornece a ferramenta Árvore da Realidade Futura. A Árvore da Realidade Futura tem como objetivo predizer as consequências da implementação da injeção, mostrando os benefícios e expondo as possíveis consequências negativas que surgiriam após a adição da injeção.

A construção da Árvore da Realidade Futura começa com as ideias criadas pela Nuvem, no exemplo apresentado, "Fazer testes e refatorar". A partir da ideia, utiliza-se relações de causa e

\footnotetext{
${ }^{8}$ O termo "dívida técnica" foi cunhado por Ward Cunningham na OOPSLA'92 [Cun92] para descrever a obrigação que uma organização de software incorre quando escolhe um design ou um tipo de construção que é prático no curto prazo mas que aumenta a complexidade e é mais custoso no longo prazo.

${ }^{9}$ Possíveis ações propostas para remover o problema-raiz.
} 
consequência, mostrando como seria a realidade da organização se a ideia fosse posta em prática. A Figura 2.14a apresenta um esboço da Árvore da Realidade Futura. Durante a construção da Árvore da Realidade Futura podem ocorrer situações nas quais efeitos benéficos resultam em consequências indesejadas (ver Figura 2.14b). Nesse caso, deve-se modificar ou criar novas ideias a fim de evitar que situações indesejadas ocorram (ver Figura 2.15). Após a criação e validação da Árvore da Realidade Futura, um retrato de como a organização se comportaria no futuro é criado, respondendo a pergunta "para o que mudar?". Para responder a pergunta "Como causar a mudança?", os obstáculos que impedem a implementação da solução devem ser identificados e um plano para mudança deve ser formulado.

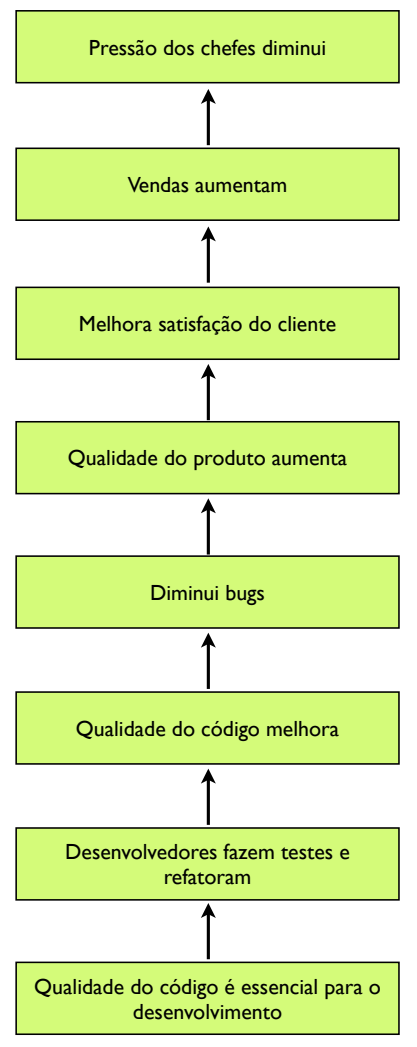

(a) Sem ramificação negativa.

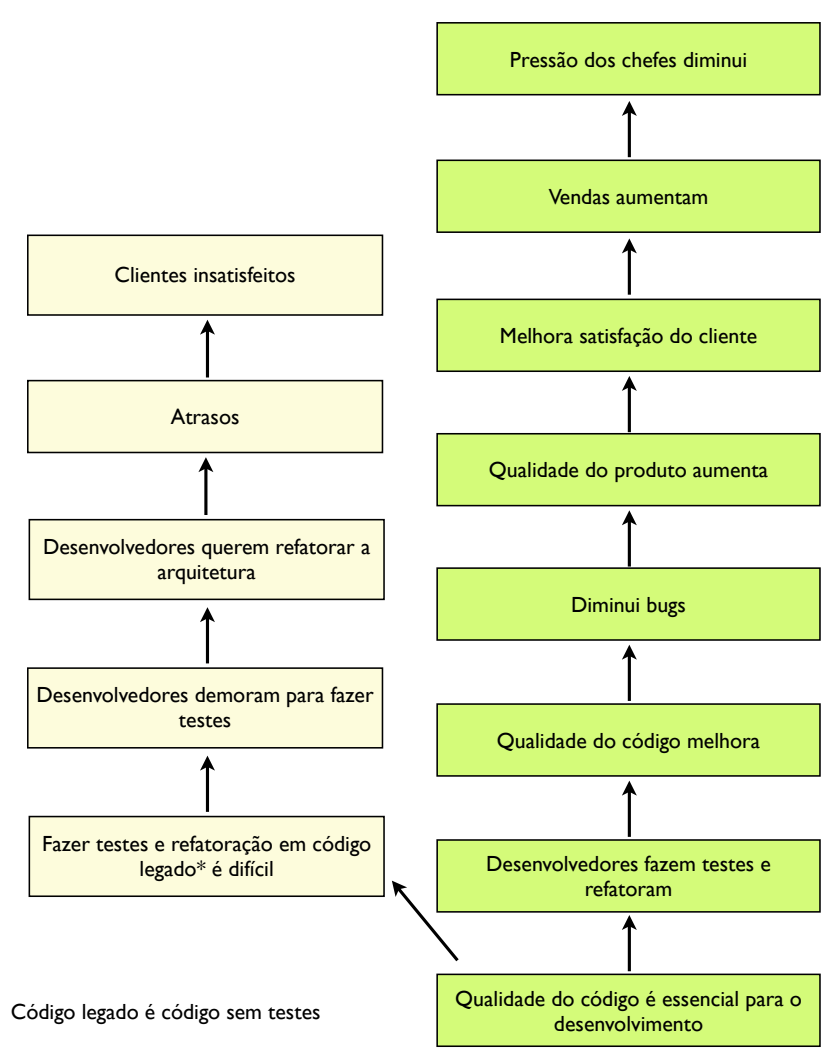

(b) Com ramificação negativa.

Figura 2.14: Árvore da Realidade Futura. Exemplo baseado no caso real descrito por Tom Poppendieck e Henrik Kniberg para Deep Lean 2009 em Stockholm e Agile 2009 em Chicago.

Fonte: http://www.crisp.se/lean/a3-template 


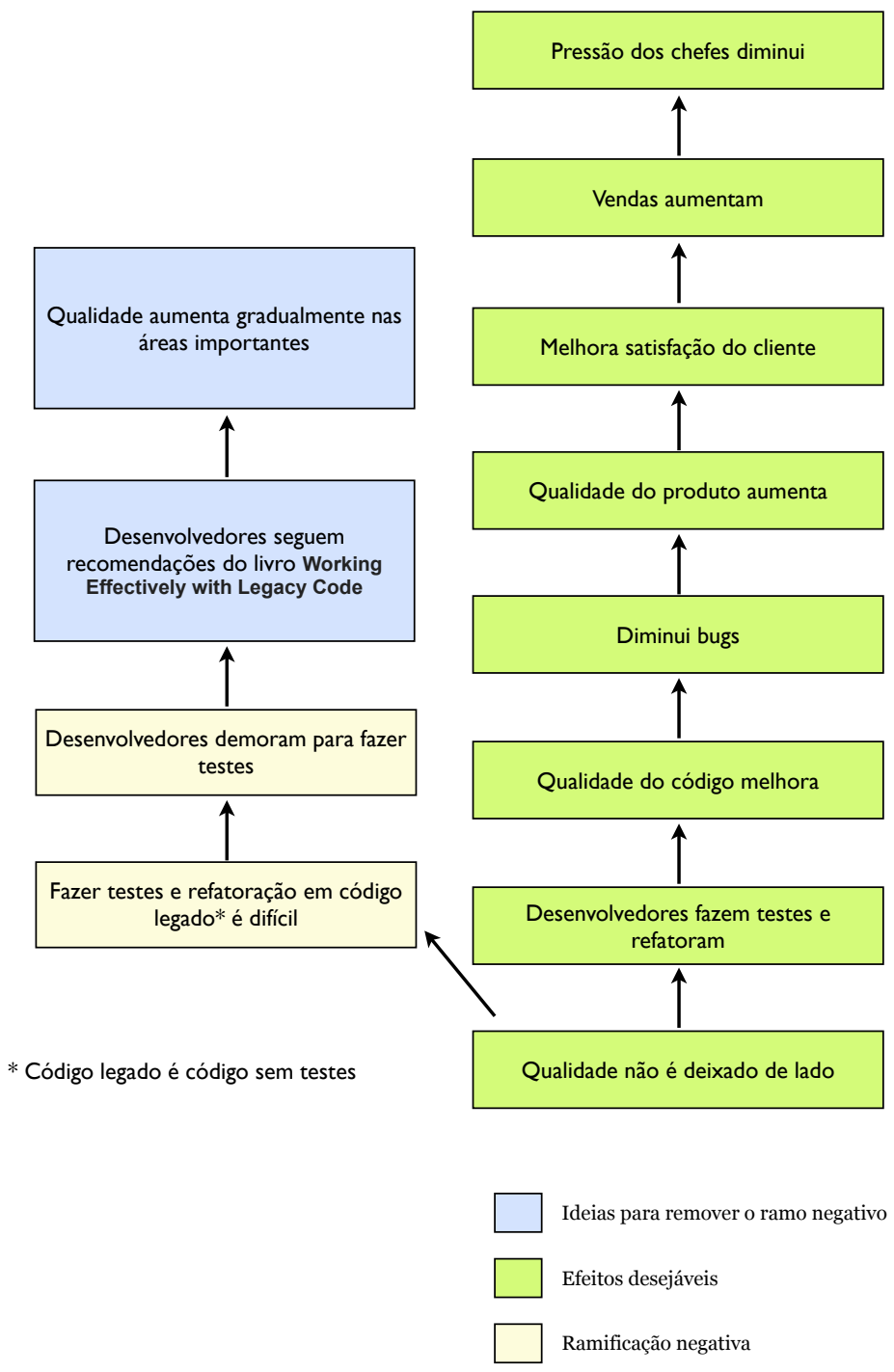

Figura 2.15: Árvore da Realidade Futura com ramo negativo removido. Exemplo baseado no caso real descrito por Tom Poppendieck e Henrik Kniberg para Deep Lean 2009 em Stockholm e Agile 2009 em Chicago.

Fonte: http://www.crisp.se/lean/a3-template

Para identificar os obstáculos que impedem a implementação da solução, a Teoria das Restrições fornece a ferramenta Árvore de Pré-requisito que responde a pergunta "O que deve ser feito para iniciar a mudança?". A construção da Árvore de Pré-requisito começa com a identificação dos principais obstáculos que impedem a ideia de ser implementada. Após a identificação dos obstáculos, ações são criadas para determinar quando um obstáculo foi superado. A Figura 2.16 apresenta os obstáculos e objetivos intermediários para a injeção "Desenvolvedores criam testes e refatoram durante o desenvolvimento". 


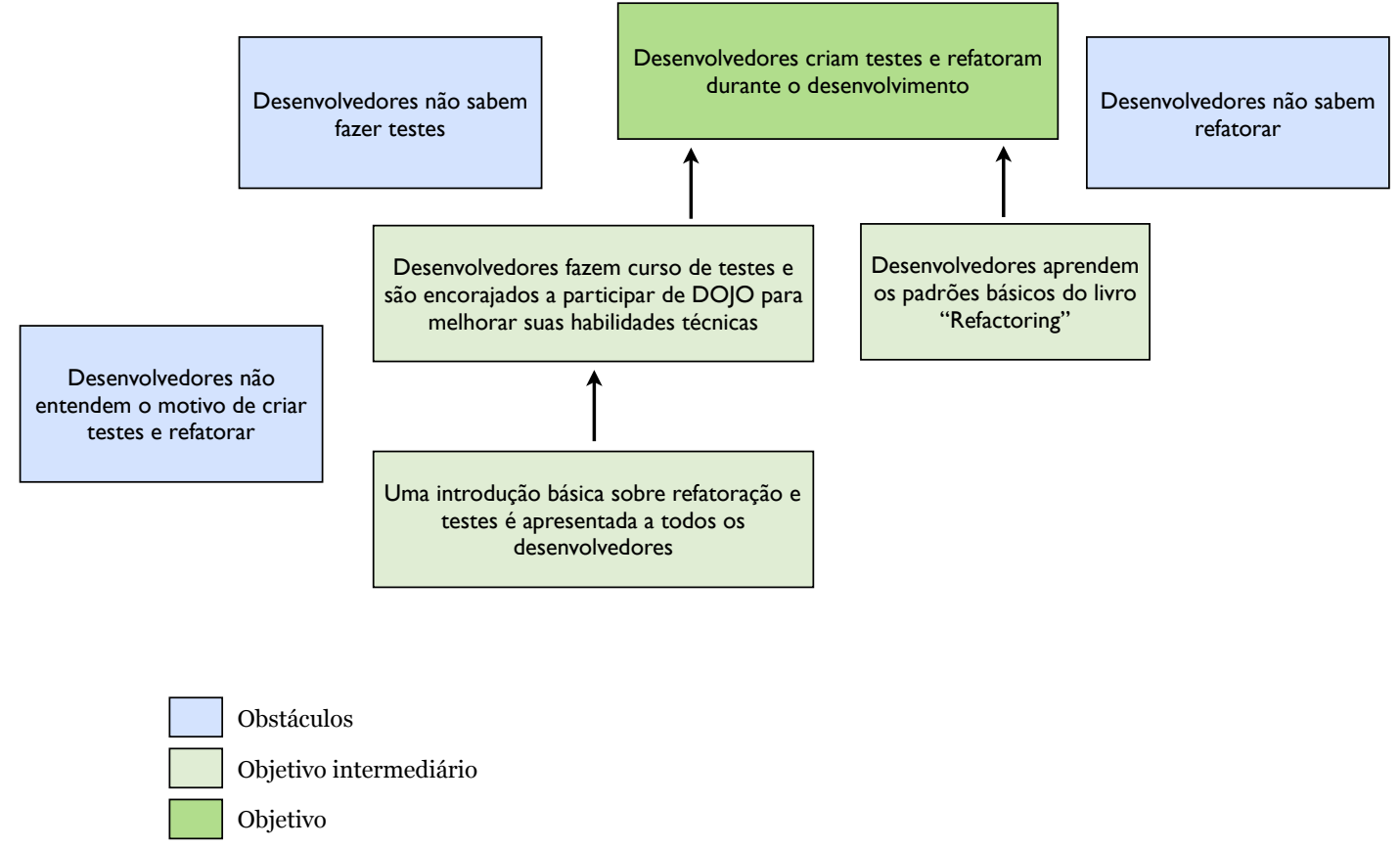

Figura 2.16: Árvore de Pré-requisito para a injeção "Desenvolvedores criam testes e refatoram durante o desenvolvimento". Exemplo baseado no caso real descrito por Tom Poppendieck e Henrik Kniberg para Deep Lean 2009 em Stockholm e Agile 2009 em Chicago.

Fonte: http://www.crisp.se/lean/a3-template

Finalmente, a Árvore de Transição fornece uma forma de construir um plano de ação de forma que as necessidades, ações recomendadas e pressupostos sejam expostos claramente. Além da Árvore de Transição ser excelente para o planejamento de atividades importantes, ela também pode ser utilizada para monitorar a execução do plano, mostrando quando ações necessárias devem ser executadas e quando ações desnecessárias ou que possuem efeitos colaterais devem ser evitadas. A Figura 2.17 apresenta a Árvore de Transição para a injeção "Desenvolvedores criam testes e refatoram durante o desenvolvimento". 

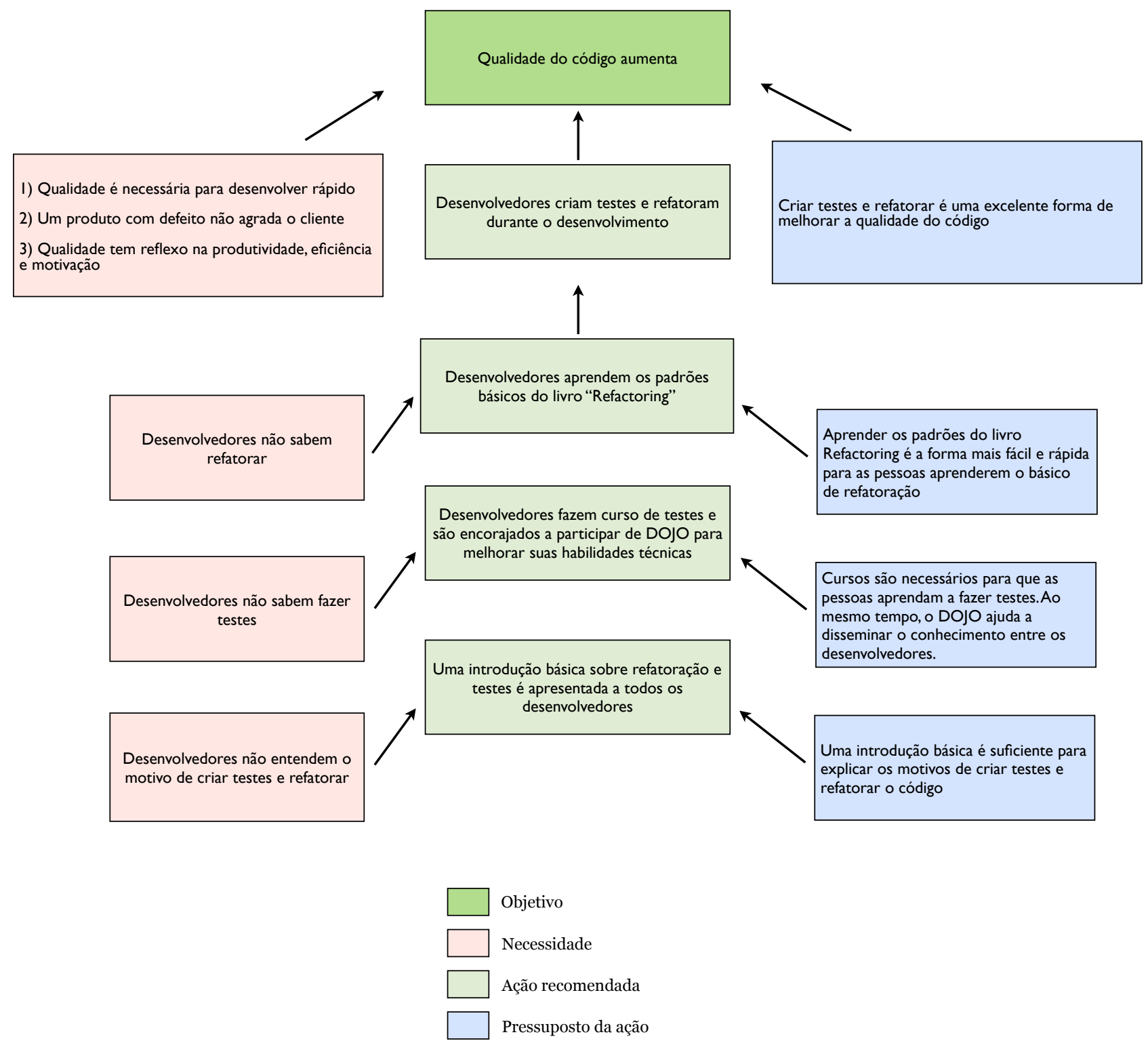

Figura 2.17: Árvore de Transição para a injeção "Desenvolvedores criam testes e refatoram durante o desenvolvimento". Exemplo baseado no caso real descrito por Tom Poppendieck e Henrik Kniberg para Deep Lean 2009 em Stockholm e Agile 2009 em Chicago.

Fonte: http://www.crisp.se/lean/a3-template

\subsubsection{Práticas}

\section{Tambor-pulmão-corda (Drum-buffer-rope)}

O tambor-pulmão-corda é um sistema de escalonamento que se concentra na capacidade da restrição do recurso fazendo com que todo o sistema seja subordinado a ela. O objetivo da solução é proteger a restrição do sistema da variabilidade de suas dependências, maximizando o desempenho do sistema como um todo. Os principais benefícios são [SWS06]: 
- Um sistema previsível e confiável que sempre opera perto da capacidade máxima;

- Redução de estoque;

- Menos defeitos e re-trabalhos.

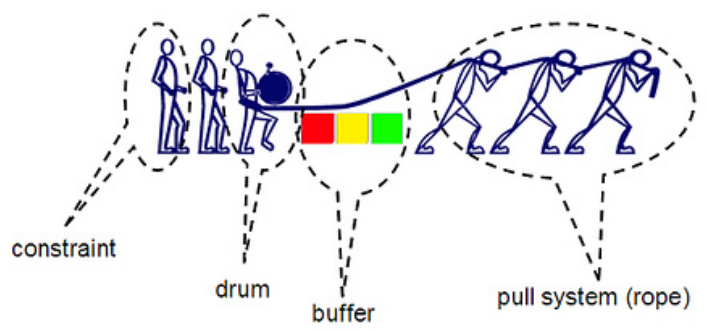

Figura 2.18: A figura mostra uma representação do método tambor-pulmão-corda. Referência: http://www.shmula.com/138/shmula-goes-camping-drum-buffer-rope

A Figura 2.18 mostra uma representação do método tambor-pulmão-corda. Nos antigos exércitos, o tambor indicava o ritmo da marcha das tropas. Na Teoria das Restrições, o tambor (recurso com restrição de capacidade) indica o ritmo da produção do sistema. Goldratt afirma que como o tambor determina o desempenho do sistema, a capacidade dele nunca deve ser desperdiçada. No entanto, devido a variabilidade do sistema, existem momentos em que as dependências que precedem o recurso com restrição de capacidade não conseguem produzir o suficiente para mantê-lo em funcionamento. Para evitar essa situação, utiliza-se uma proteção, representada por uma corda frouxa, chamada de pulmão ou buffer. Com o intuito de evitar que super-produção ocorra em outras estações, a Teoria das Restrições utiliza a corda, um mecanismo de sincronização que programa a liberação de matéria-prima para outras estações de acordo com o tambor.

\section{Corrente Crítica}

A Corrente Crítica ou CCPM (Critical Chain Project Management) é a aplicação da Teoria das Restrições para planejamento e gerenciamento de projetos. Segundo Goldratt [GK09], a maior parte dos problemas de atrasos em projetos são decorrentes das datas de entrega dos projetos serem estimadas com muita folga para que eles sejam entregues no prazo.

No gerenciamento de projetos é comum a premissa que para finalizar um projeto no prazo, todas as tarefas devem ser finalizadas dentro do prazo. Essa premissa faz com que alguns gerentes avaliem o desempenho de equipes e indivíduos com base na confiabilidade da estimativa. Como consequência, as pessoas superestimam suas tarefas para que tenham confiança de terminá-las no prazo estimado (ver Figura 2.19).

Em um planejamento típico de projeto, a equipe que realizará o projeto estima a duração das tarefas. Após todos estimarem, o gestor adiciona um tempo de folga para que imprevistos não atrasem a entrega. No entanto, mesmo em projetos superestimados, é normal que ocorram atra- 


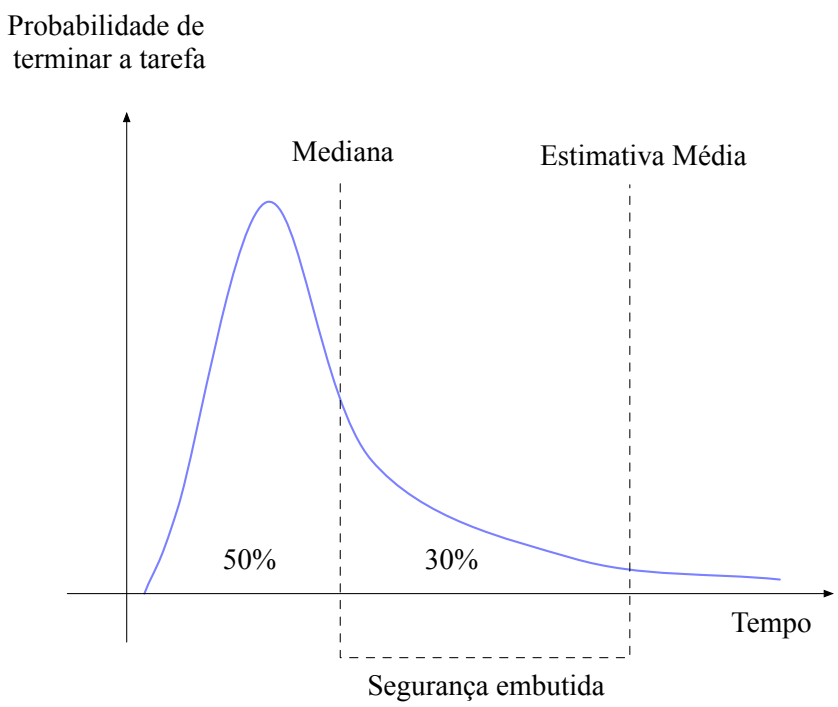

Figura 2.19: A figura mostra uma tarefa que possui excesso de margem de segurança, com relação ao tempo. Referência: Livro Corrente Crítica [Gol97]

sos [Gro94]. Goldratt afirma que os atrasos são decorrentes de quatro problemas que desperdiçam a margem de segurança adicionada nas tarefas:

\section{As atividades raramente terminam antes do tempo estimado}

Durante a execução de um projeto é normal que as tarefas raramente terminem antes do tempo estimado. Esse fato pode ser explicado pela Lei de Parkinson [PO57], "O trabalho expande-se de modo a preencher o tempo disponível para sua realização". No seu livro Parkinson's Law: The Pursuit of Progress [PO57], Parkinson apresenta diversos exemplos em que a percepção da tarefa aumenta de importância e de complexidade conforme o tempo alocado para sua realização. Um exemplo apresentado é de uma velha senhora capaz de ocupar um dia inteiro para enviar um cartão postal, atentando-se excessivamente na escolha da paisagem do cartão, perdendo tempo procurando os óculos ou o endereço do destinatário, escrevendo e rescrevendo com calma a mensagem e ainda contemplando a necessidade de levar um guarda-chuvas no seu passeio até a agência dos correios. Entretanto, um homem ocupado seria capaz de executar a mesma tarefa em três minutos.

\section{O início de uma atividade é adiada até o último momento possível}

Em gerenciamento de projetos, a tendência natural de iniciar uma atividade no último momento possível é conhecida como Síndrome do Estudante [wik]. O termo refere-se a um comportamento no qual os estudantes começam a se dedicar a uma tarefa na véspera do seu prazo final. Por exemplo, quando um grupo de estudantes possui uma tarefa perto do prazo final, eles irão até o professor e pedirão por um adiamento do prazo final de entrega argumentando que seus projetos serão melhores se eles tiverem mais tempo para trabalhar neles. Os alunos pedem um adiamento do prazo com a intenção de distribuir o tempo de 
trabalho pelo tempo que sobra até o prazo de entrega. Porém, a maioria dos estudantes possui outras tarefas ou eventos que também demandam seu tempo. Logo, o tempo ganho com o adiamento do prazo é desperdiçado e os estudantes se encontrarão na mesma situação de antes: desejando mais tempo livre e começando a se dedicar à tarefa apenas na véspera do prazo.

\section{Os atrasos são propagados pelo projeto}

O plano é o conjunto de atividades necessárias para que o objetivo do projeto seja alcançado. Tradicionalmente, os gerentes de projeto utilizam Gantt Charts para ter uma visão geral de todas as atividades e interdependências. A Figura 2.20 apresenta um exemplo simplificado de Gantt Chart de quatro atividades e suas interdependências. Nela é possível observar os dois tipos de dependências existentes: a dependência sequencial e a dependência paralela.

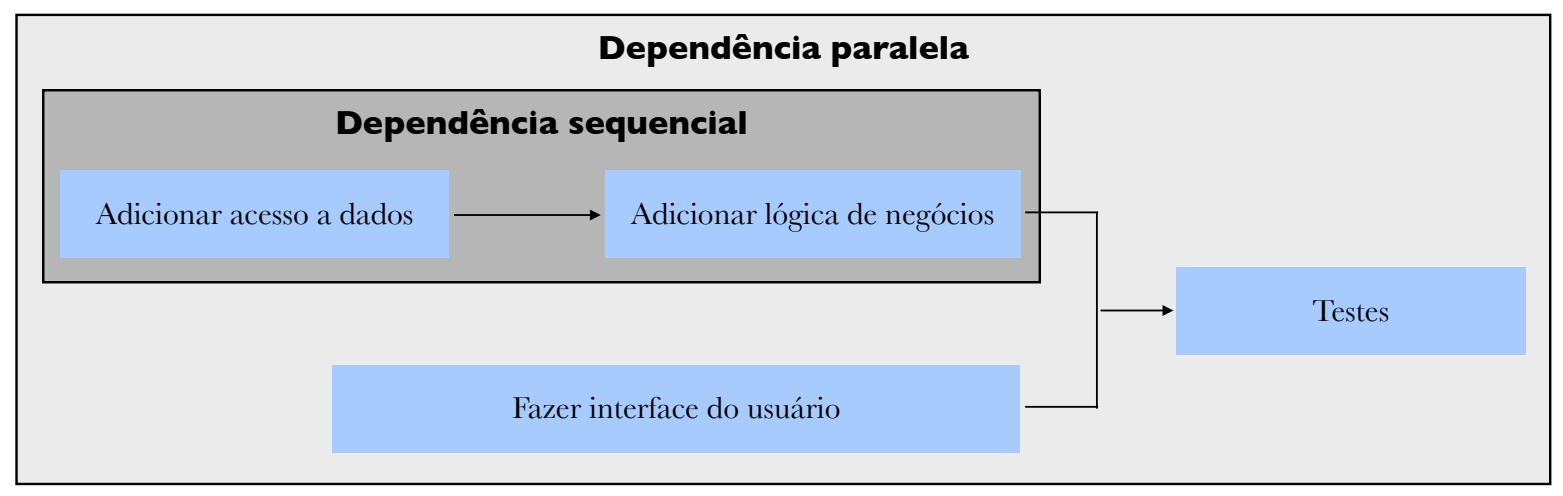

Figura 2.20: A figura apresenta quatro atividades e suas interdependências. Fonte: Agile Estimating and Planning [Coh06]. Mike Cohn

Quando as atividades possuem dependência sequencial o atraso de uma atividade pode ser compensada pelo término antecipado de outra atividade. No entanto, devido a Lei de Parkinson as atividades raramente terminam antecipadamente. Como consequência, apenas os atrasos são propagados pelo projeto, não existindo uma compensação pelos términos antecipados.

Quando as atividades possuem dependência paralela, o início da próxima atividade depende do término de todas as tarefas precedentes. Quando uma tarefa atrasa, a próxima atividade não pode iniciar mesmo que as outras atividades já tenham sido finalizadas, pois uma tarefa precedente ainda não foi finalizada. Portanto, o término antecipado de uma tarefa só pode ser aproveitado se todas as atividades paralelas terminarem antecipadamente. Como consequência, é comum que apenas os atrasos sejam propagados pelo projeto.

\section{Multitarefa}

A multitarefa ocorre quando uma pessoa trabalha em mais de uma tarefa simultaneamente. Um dos problemas da multitarefa é que quando duas ou mais tarefas são executadas simultaneamente o tempo gasto por ela trabalhando nas atividades decresce [CW93]. A Figura 2.21 
apresenta o efeito da multitarefa na produtividade de uma pessoa. Na Subseção 3.1.1 outros problemas decorrentes da multitarefa serão apresentados.

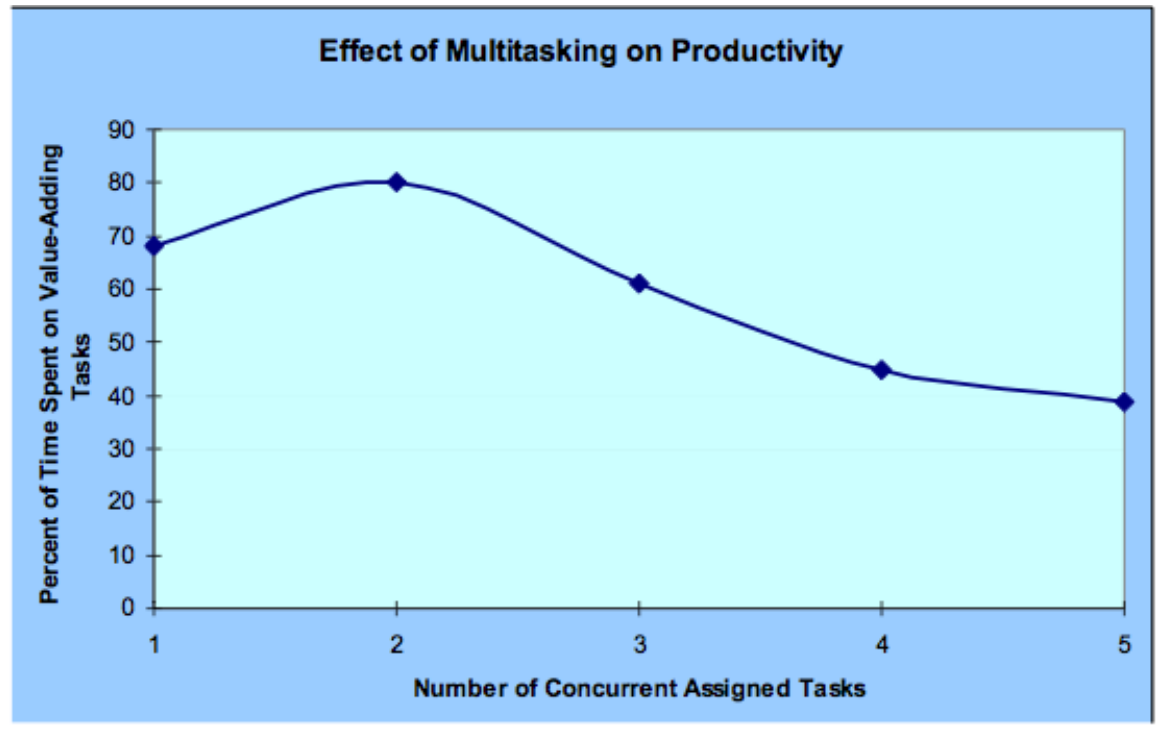

Figura 2.21: Efeito da multitarefa na produtividade. Fonte: Agile Estimating and Planning [Coh06]. Mike Cohn

No planejamento prescritivo de projetos, os problemas decorrentes da multitarefa são amplificados devido a duas causas [Coh06]:

(a) Embora seja impossível distribuir as atividades eficientemente antes do projeto iniciar, os gestores tentam distribuir as atividades antes do início do projeto. Quando atrasos ocorrem, as pessoas que estão esperando as tarefas precedentes irão pedir que a pessoa com a tarefa atrasada inicie a atividade que elas necessitam. No entanto, como será visto na Subseção 3.1.1, quando atividades são feitas simultaneamente nenhuma tarefa é finalizada no tempo mínimo. Dessa forma o progresso total das atividades diminui e mais atrasos ocorrem;

(b) Os gestores são encorajados a maximizar a eficiência da pessoas. No entanto, utilizar todas as pessoas na capacidade máxima possui o mesmo efeito que congestionar uma via rápida. Adicionando o máximo de carros possível, ninguém consegue progredir.

Goldratt sugere que para entregar o projeto no prazo estimado, deve-se mudar o foco de "terminar cada tarefa no prazo" para "terminar o projeto no prazo" [BC10]. A solução da Corrente Crítica propõe que as margens de segurança de cada tarefa sejam removidas e acumuladas em um buffer de tempo que protegerá o projeto como um todo. Dessa forma, cada tarefa pode ser terminada mais rapidamente e possíveis atrasos na tarefa podem ser absorvidos pelo buffer do projeto. Um exemplo de uso da Corrente Crítica no desenvolvimento de software será apresentado na Subseção 3.2.1. 


\subsubsection{Conclusão}

Essa Seção apresentou a Teoria das Restrições, descrevendo seus princípios, práticas e o processo utilizado para realizar melhorias contínuas em uma organização. Assim como a abordagem da manufatura Lean, a Teoria das Restrições busca melhorar o fluxo do processo ao enxergar a organização como um sistema em que todas as partes são inter-relacionadas.

Partindo da premissa de que um sistema sempre possui pelo menos uma restrição, Goldratt formulou um processo para auxiliar a organização a entrar em um processo de melhoria contínua. Esse processo é composto por cinco passos:

1. Identificar a restrição do sistema;

2. Decidir como utilizá-la ao máximo;

3. Subordinar e sincronizar o sistema a restrição;

4. Elevar a restrição do sistema;

5. Se em um passo anterior a restrição foi quebrada, volte ao passo 1. Mas não permita que a inércia cause uma restrição do sistema.

Os cinco passos são a base para todas as soluções de melhoria propostas por Goldratt. Apesar de sua origem ter sido na manufatura, atualmente a Teoria das Restrições tem sido aplicada em diversos ambientes (e.g. logística, contabilidade, marketing, etc...) obtendo excelentes resultados que são amplamentes descritos na literatura [MB00]. Na Seção 3.2 algumas formas de utilizar a Teoria das Restrições no desenvolvimento de software serão apresentadas.

\subsection{A importância de uma visão global}

System Thinking [Wei75] é uma abordagem que enxerga uma organização como um sistema ${ }^{10}$, analisando como as partes de uma organização interagem com outras e para isso, ela inclui todas as suas estruturas e padrões ao invés de olhar especificamente para alguns eventos dentro do sistema. Esta teoria afirma que o único modo de entender o motivo que leva um problema a ocorrer e ainda persistir é entender a parte em relação ao todo. Devido as suas características, esta técnica é particularmente eficaz resolvendo problemas complexos, como: problemas em que existem uma grande dependência entre decisões passadas e ações externas, e problemas que ocorrem devido a má coordenação entre as partes envolvidas.

No decorrer dos anos, diversos padrões de comportamentos foram identificados quando uma organização não possui uma visão global. O Limit to Growth ocorre quando uma organização realiza uma determinada ação para produzir um período de crescimento acelerado, ou expansão. Após este período de expansão, a velocidade do crescimento diminui e eventualmente para, podendo criar um período de desaceleração. A redução da velocidade é causada por um efeito secundário que surge

\footnotetext{
${ }^{10} \mathrm{Um}$ sistema é um conjunto de elementos interdependentes construídos para um propósito sendo que a habilidade total do sistema para atingir o objetivo depende de quão bem as partes trabalham junto, não dependendo apenas de como os elementos funcionam independentemente.
} 
quando um determinado limite é alcançado; se tentarmos continuar empurrando o crescimento, o processo inteiro entra em colapso devido a ação maior deste efeito secundário. Para que isto não ocorra, devemos encontrar e remover estes limites de crescimento [Sen06]. Encontrar e remover limites é o principal conceito da Teoria das Restrições. A principal ideia deste conceito é procurar e remover a restrição do crescimento, e ao mesmo tempo reconhecer que a restrição pode mudar de lugar assim que a antiga restrição é tratada. Muitas vezes as restrições do passado acabam se tornando as restrições atuais [GSP00].

Um outro comportamento comum é o Shift the burden no qual uma solução provisória é utilizada para corrigir um problema e ela obtém resultados positivos imediatos, entretanto, a causa do problema continua sendo evitada. Ao utilizarmos cada vez mais a solução provisória, a solução para a causa do problema se torna cada vez mais distante [Sen06]. Os métodos da manufatura estudados, utilizam de duas técnicas diferentes para solucionar esse problema. Enquanto Lean Thinking utiliza a técnica dos Cinco Porquês para evitar a tendência do Shift the burden, a Teoria das Restrições utiliza os Processos de Raciocínio para descobrir a causa real do problema.

Um outro padrão comum em organizações que não possuem uma visão global é o Suboptimization. Quanto mais complexo o sistema, maior é a tentação de dividir em partes e gerenciá-las localmente. Ao gerenciarmos localmente, existe uma tendência de criarmos medidas para avaliar o desempenho. Essas medidas de desempenho acabam criando um efeito no sistema global que diminui a produtividade total do sistema [PP03].

Em seu livro Measuring and Managing Performance in Organizations [ADL96], Austin traz a premissa de que as pessoas irão tentar otimizar as medidas de desempenho a que são submetidas. O problema disto, é que é muito difícil criar medidas de desempenho para tudo o que é importante, e medidas de desempenho parciais possuem uma grande probabilidade de se tornarem medidas de desempenho subotimizadas. Segundo Austin, quando não é possível medir tudo o que é necessário para otimizar o objetivo do sistema como um todo, é melhor não possuir medidas subotimizadas de desempenho.

Infelizmente, medidas de desempenho são consideradas fundamentais na cultura dos negócios. Austin nota que como a maioria dos gerentes querem utilizar medidas de desempenho, eles tentam criar três medidas de desempenho que cobrem tudo. Eles fazem isso de três formas [PP03]:

1. Padronização: padronizações são realizadas ao abstrair o processo de desenvolvimento em fases sequenciais e padronizando como cada uma deve ser feita. Quando isto é feito, eles realizam a medição de acordo com o processo;

2. Especificação: são criadas especificações e planos detalhados, e então são realizadas as medições do desempenho e da variação do plano;

3. Decomposição: tarefas grandes são quebradas em menores e cada uma é medida independentemente.

Esta forma de gerenciar é muito parecida com a forma de gerenciamento dos métodos tradicio- 
nais de desenvolvimento de software e, infelizmente, essa forma de gerenciar encoraja o comportamento de subotimização.

Lean Thinking tenta fazer medições através de agregação, isto é, ele mede um nível acima. Por exemplo, ao invés de medir o desempenho de uma pessoa, ele mede o desempenho do grupo [PP03]. A importância da visão global também é observada no processo de desenvolvimento de software. No próximo capítulo, serão apresentado os métodos de desenvolvimento de software baseados na indústria de manufatura que visam evitar esses comportamentos negativos. 
40CAPÍTULO 2. MÉTODOS DE DESENVOLVIMENTO DA INDÚSTRIA DE MANUFATURA 


\section{Capítulo 3}

\section{Métodos de desenvolvimento de software}

Nos últimos anos, os Métodos Ágeis de desenvolvimento de software ganharam importância em diversos segmentos da indústria de software, tornando-se uma das abordagens predominantes [WGGD10]. Assim como os métodos tradicionais, os Métodos Ágeis têm por objetivo construir sistemas de alta qualidade que atendam às necessidades dos usuários. As principais diferenças estão nos princípios e valores utilizados para atingir tal objetivo.

Os Métodos Ágeis apresentam uma abordagem pragmática para o desenvolvimento de software. Planos detalhados são feitos apenas para a fase atual do projeto. Para fases futuras, os planos são considerados apenas rascunhos que podem se adaptar a mudanças conforme a equipe aprende e passa a conhecer melhor o sistema [Sat07]. Nesse tipo de desenvolvimento, o cliente possui um controle muito mais refinado sobre o processo, podendo verificar o progresso e alterar a direção do desenvolvimento se necessário. Isso leva a um relacionamento mais próximo dos clientes com os desenvolvedores. No entanto, possuir um processo adaptativo não é fácil. Particularmente, exige uma equipe que consiga trabalhar sinergicamente e que seja eficaz tecnicamente [Fow00].

Nos últimos anos, diversos princípios e práticas baseadas na indústria de manufatura foram absorvidas pelos Métodos Ágeis. Poppendieck \& Poppendieck aplicaram os princípios da Manufatura Lean no desenvolvimento de software, criando o método Lean Software Development [PP03, PP06]. No seu livro Managing the Design Factory [Rei97], Reinertsen discute os benefícios de aplicar os princípios da Manufatura Lean no desenvolvimento de produtos, inclusive software. Goldratt escreveu sobre gargalos nas estações de trabalho da manufatura [GC84] e, posteriomente, expandiu sua teoria para diversas áreas [Gol90]. Anderson aplicou os conceitos da Teoria das Restrições para melhorar o fluxo e controlar o tamanho de filas no desenvolvimento de software [And04a]. Finalmente, Cockburn escreveu sobre algumas estratégias para lidar com gargalos que alcançaram suas capacidades máximas [Coc05].

Este capítulo apresenta as abordagens de desenvolvimento de software que foram baseadas nos métodos de manufatura estudados no Capítulo 2. Além disso, algumas práticas são apresentadas de forma que possam ser combinadas aos Métodos Ágeis para tornar a equipe de desenvolvimento mais eficaz e produtiva. 


\subsection{Lean Software Development}

O termo Lean Software Development [PP03] teve origem com o livro lançado por Mary e Tom Poppendieck, com o mesmo nome. Neste livro, os conceitos de Lean são sintetizados e adaptados para o desenvolvimento de software, fornecendo sete princípios fundamentais.

Posteriormente, eles publicaram o livro Implementing Lean Software Development [PP06] e alguns dos sete princípios tiveram seus nomes modificados, porém, a essência deles continuou inalterada. O primeiro passo para aplicar Lean Software Development é entender os princípios, que serão explicados a seguir.

\subsubsection{Princípios}

Princípios são verdades básicas que não mudam com o passar do tempo ou de acordo com o local, enquanto práticas são aplicações de princípios para uma situação em particular. Práticas podem e devem mudar quando o ambiente é mudado ou quando a situação evolui [PP06].

Os princípios ajudam a ter uma visão mais concreta dos valores, além de fornecer diretrizes para tomadas de decisões [BA04]. Por outro lado, as práticas oferecem uma direção específica sobre o que fazer, mas necessitam de adaptação de acordo com o domínio [PP03].

Os sete princípios de Lean Software Development são:

\section{1 - Elimine desperdícios}

A filosofia de eliminar desperdícios sempre esteve presente na história da Toyota. Isso foi demonstrado quando Taiichi Ohno fez sua jornada no chão de fábrica, aprendendo a identificar quais atividades agregavam valor ao produto e quais atividades poderiam ser retiradas por não adicionar valor [Lik04]. No seu livro Toyota Production System [Ohn88], Ohno afirma que a base do sistema Toyota é a total eliminação do desperdício.

Para eliminar o eventual desperdício, é necessário reconhecê-lo. Como desperdício é qualquer atividade que não agrega valor, o primeiro passo para utilizar Lean é entender o que é valor e quais atividades e recursos são absolutamente necessários para criá-lo [PP06]. A primeira questão que deve ser respondida é: "O que o cliente deseja deste processo?". Através da perspectiva do cliente, o processo é observado e as etapas que agregam valor são separadas das etapas que não o agregam. O Mapa de Fluxo de Valor, apresentado na Subseção 3.1.2, é uma ferramenta eficaz para auxiliar nesta tarefa.

Aprender a enxergar o desperdício é um processo contínuo de mudança na forma de se pensar sobre o que é realmente necessário [PP03]. Ao eliminar os desperdícios é possível reduzir os custos de desenvolvimento, tornando-o mais eficiente.

Shingo identificou os sete principais tipos de desperdícios que ocorrem na manufatura [Shi89]. Womack, no seu livro Lean Thinking [WJ03] identificou mais um. No entanto, independente da quantidade de desperdícios existentes, é difícil refutar o argumento de que existe desperdício em todos os lugares [WJ03]. A Tabela 3.1 apresenta os sete tipos de desperdícios na manufatura identificados por Shingo, que posteriormente foram mapeados para o desenvolvimento de software por Poppendieck \& Poppendieck [PP06]: 
Tabela 3.1: Os sete principais tipos de desperdícios que ocorrem na manufatura e no desenvolvimento de software.

\begin{tabular}{l|l} 
Na manufatura & No desenvolvimento de software \\
\hline Inventário & Trabalho parcialmente feito \\
Superprodução & Funcionalidade extra \\
Processamento extra & Reaprendizado \\
Movimentação & Handoff \\
Transporte & Multi-tarefa \\
Tempo de espera & Tempo de espera \\
Defeitos & Defeitos
\end{tabular}

1. Trabalho parcialmente feito

O objetivo em Lean é ter desde o início do trabalho um sistema em que o código seja integrado, testado, documentado e implantado em um único, e rápido fluxo. Uma maneira para realizar isto é dividindo o trabalho em pequenas tarefas ou em iterações [PP06].

Em desenvolvimento de software, inventário é qualquer trabalho parcialmente feito: requisitos coletados que não foram analisados, designs que não foram codificados, código que não foi testado e integrado, funcionalidades prontas que não foram entregues ao cliente, etc...

Quando o fluxo de valor do software possui o mínimo possível de trabalho parcialmente feito os riscos são reduzidos e a produtividade é melhorada [BP04].

2. Funcionalidade extra

Segundo Taiichi Ohno [Ohn88], a produção desnecessária de produtos é o pior tipo de desperdício, pois ela gasta esforços para ser feita, gera produtos que não são necessários imediatamente e aumenta os custos de estoque. Se esse desperdício fosse evitado, o esforço poderia ser gasto em atividades que agregam valor ao cliente.

Analogamente, o pior tipo de desperdício em desenvolvimento de software é criar funcionalidades que não são necessárias para o cliente. Segundo Johnson [Joh02], uma grande proporção de funcionalidades criadas não são utilizadas. Para embasar sua afirmação, ele utiliza dois estudos:

- Um estudo da DuPont que afirma que apenas 25\% das funcionalidades de um sistema são realmente necessárias [Joh02];

- Um estudo do Standish Group [Gro94] que afirma que 45\% das funcionalidades feitas não são utilizadas e $19 \%$ são raramente utilizadas.

3. Reaprendizado

Reaprendizado é considerado a terceira maior causa de desperdício no desenvolvimento de software. O desperdício em reaprendizado refere-se ao tempo gasto em aprender algo que já era conhecido pela equipe ou o tempo gasto em refazer tarefas que já estavam feitas. 
Normalmente, o retrabalho ocorre quando é necessário compensar erros criados devido a requisitos mal interpretados, especificação erradas, código de baixa qualidade e documentação não atualizada [BP88]. Alguns estudos [JJ86, CJO03] apontam que em grandes projetos, o custo de retrabalho é tipicamente maior do que $50 \%$ do custo total do projeto e que o custo de refazer um trabalho é muito menor nas fases iniciais do projeto [Fag76, DeM86, Boe76].

4. Multitarefa

Frequentemente, as organizações atribuem a seus desenvolvedores diversas tarefas para serem feitas. Quando um desenvolvedor faz mais de uma tarefa simultaneamente, ele está realizando multitarefa.

Um dos problemas da multitarefa é que quando as tarefas são feitas simultaneamente, nenhuma tarefa é finalizada no tempo mínimo. A Figura 3.1 ilustra esse problema.

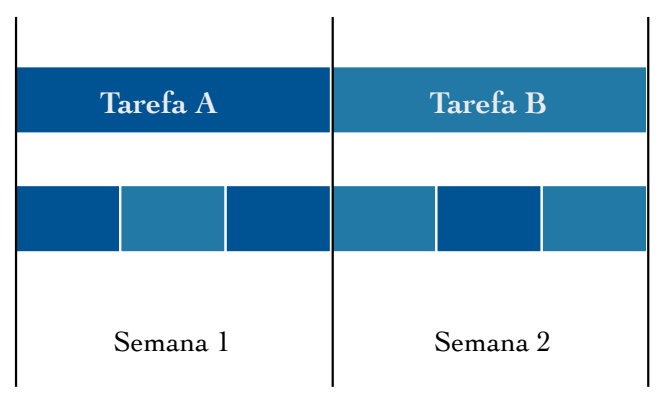

Figura 3.1: O uso da multitarefa faz com que nenhuma das tarefas seja terminada em 1 semana. Essa figura desconsidera o custo por troca de contexto.

Um outro problema é o custo entre as trocas de tarefas. Em um estudo realizado por pesquisadores dinamarqueses para avaliar a capacidade e limitação humana para multitarefa, foi apontado que sempre existe custo entre as trocas de tarefas [RME01].

No seu livro Quality Software Management: Systems Thinking [Wei92], Weinberg sugere a regra apresentada na Figura 3.2 para calcular o desperdício causado por troca de contexto entre projetos. Segundo os cálculos de Weinberg, adicionar um projeto na sua lista de tarefas é muito debilitante, pois ocorre uma perda de $20 \%$ do seu tempo. Ao adicionar um terceiro projeto na sua lista de tarefas, quase metade do tempo é desperdiçado devido a troca de contexto.

No livro PeopleWare [DL99], DeMarco e Lister descrevem fluxo, como um estado de concentração altamente produtivo necessário para desenvolver software. Segundo os autores, são necessários cerca de 15 minutos para um desenvolvedor entrar no estado fluxo. Cada vez que um desenvolvedor é interrompido ou troca de tarefa, 15 minutos de produtividade são desperdiçados até que ele alcance o estado de concentração ideal para desenvolver. Durante o período pré-fluxo muito pouco trabalho é realizado. 


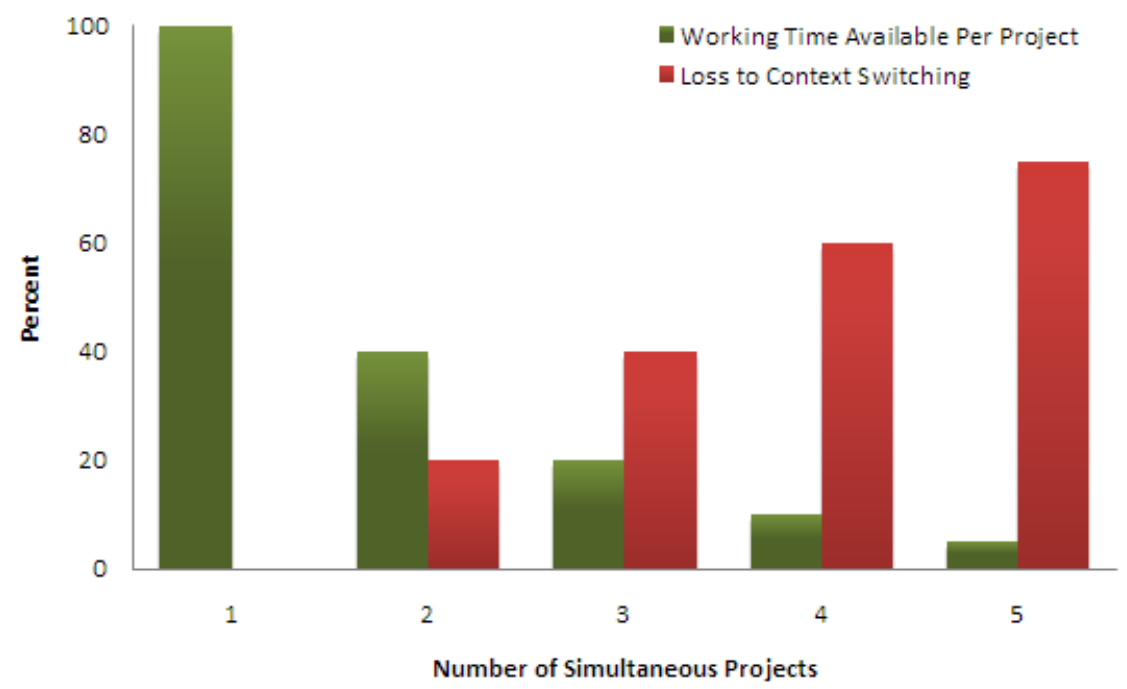

Figura 3.2: A figura mostra o custo da troca de contexto quando um ou mais projetos são feitos simultaneamente. Fonte: http://www.codinghorror.com/blog/archives/000691.html. Retirado em Setembro de 2009.

\section{Handoff}

No seu livro, Lean Product and Process Development [War07], Allen Ward afirma que handoff é a maior causa de desperdício no desenvolvimento de produtos. Um handoff ocorre quando responsabilidade, conhecimento, ação e feedback são separados. Equipes que utilizam desenvolvimento sequencial geralmente possuem handoffs em todas as etapas de desenvolvimento [Coh10].

Alan Cooper [Coo08], afirma que o desenvolvimento em Cascata não apenas transfere a ação de uma tarefa, como também tira a responsabilidade da pessoa pelo trabalho: a equipe de arquitetos, isoladamente, cria a arquitetura do projeto e passa para a equipe de desenvolvimento, que após desenvolver, transfere o trabalho e a responsabilidade para a equipe de testes. Durante o processo de transferência de uma tarefa para outra pessoa, ocorrem distorções na passagem de informação, pois uma parte do conhecimento tácito é perdido, o que pode resultar em requisitos mal interpretados.

6. Tempo de espera/Atrasos

Durante o desenvolvimento de software é comum a demora para iniciar atividades, organizar equipes, aguardar um levantamento detalhado de requisitos, colocar o sistema em produção, sanar uma dúvida com o cliente, etc... Geralmente, essa demora para iniciar uma atividade pode ser observada analisando o tamanho da fila de atividades a serem feitas, quanto maior o tamanho da fila, maior a demora para iniciar a atividade. Esperar para realizar uma atividade é tão comum que faz com que seja contra-intuitivo imaginar que a espera é na verdade desperdício [PP03].

$\mathrm{Na}$ perspectiva do cliente, essas esperas correspondem a atrasos no desenvolvimento que o impede de obter feedback rápido, fazendo com que decisões não possam ser tomadas no melhor 
momento possível e às vezes, que o produto ainda satisfaça as necessidades do cliente [Pop03a]. Em ambientes e mercados muito competitivos, atrasos e esperas podem significar perda de milhões de dólares [Tho].

\section{Defeitos}

Em Lean Software Development, defeito é qualquer atividade que não deveria ser realizada. A quantidade de desperdício leva em consideração o tempo, o custo e o esforço necessário para realizar a tarefa. Sempre que um bug, que deveria ser detectado durante a fase de desenvolvimento, é encontrado na fase de produção, uma grande quantidade de tempo e energia durante o rastreamento e conserto do bug é desperdiçado.

De acordo com o National Institute of Standards and Technology [Tas02], aproximadamente 60 bilhões de dólares são desperdiçados anualmente nos Estados Unidos devido a defeitos de software ${ }^{1}$. Isso ocorre devido a mais da metade dos erros de software serem encontrados durante a fase de produção.

\section{2 - Inclua a qualidade no processo}

Incluir a qualidade no processo é uma estratégia que minimiza a inspeção após a ocorrência de defeitos através da prevenção do mesmo durante o desenvolvimento do produto. Segundo Shingo, se existe um comprometimento em eliminar defeitos, a inspeção após a ocorrência de defeitos não é uma boa estratégia, pois o problema só é detectado após a ocorrência dele [Shi89].

Shingo classifica como desperdício a inspeção após a ocorrência de defeitos [PP06]. Dijkstra, afirma que para os programadores serem mais eficientes, eles não devem desperdiçar o tempo em debug, eles simplesmente não devem introduzir bugs [Dij72]. Para isso, eles devem construir um programa do ponto de vista da demonstrabilidade (provability). Isto é, o programador deve começar informando as pré e pós condições necessárias para que o programa funcione corretamente, e então escrever um código que satisfaça elas [Fre75].

Os testes automatizados que utilizam o arcabouço de testes xUnit [Fow] declaram as condições necessárias para que o código as satisfaça. Na perspectiva dos desenvolvedores, os testes servem como especificações mostrando como pequenas unidades do código funcionam e interagem com outras para formar componentes. Um bom conjunto de testes, com 100\% dos testes sem erros, garante que quando uma falha ocorre ela é desencadeada pela última porção de código adicionada ao sistema. Isto elimina uma grande quantidade de tempo sendo desperdiçada em debugging.

No desenvolvimento de software, além dos testes automatizados, algumas práticas podem ser utilizadas para melhorar a qualidade do produto [PP10]:

- Programação Pareada: prática em que um ou mais desenvolvedores trabalham lado a lado para realizar suas tarefas promovendo o trabalho colaborativo, unindo a equipe, melhorando a comunicação e a qualidade do código. Programadores que utilizam essa prática, consideram mais alternativas de design do que se estivessem trabalhando independentemene, obtendo

\footnotetext{
${ }^{1}$ Nesse estudo, defeito é qualquer atividade que apresenta algum tipo de problema.
} 
um design mais simples e encontrando defeitos no design mais rapidamente [AW00, WK02, $\left.\mathrm{CCG}^{+} 07\right]$.

- Desenvolvimento Guiado por Testes (TDD): um dos objetivo em Lean Software Development é prevenir que defeitos sejam introduzidos no produto. O TDD é uma prática que sugere que os testes sejam escritos antes do código, trazendo benefícios como melhoria da qualidade, ênfase no desenvolvimento, preocupação com acoplamento e coesão, confiança e ritmo [Bec03]. Estudos sugerem que projetos que utilizam TDD possuem de $40 \%$ a $90 \%$ menos defeitos do que projetos que não utilizam esta prática [NMBW08].

- Integração Contínua (IC): é uma prática na qual os membros da equipe devem integrar suas alterações frequentemente. Cada integração é verificada por um build completo, geralmente automatizado, que inclui testes para detectar erros de integração o mais rápido possível. Muitas equipes acreditam que o uso de IC reduz significativamente os problemas de integração, permititindo que a equipe desenvolva um software coeso mais rapidamente [Fow06].

- Clareza do código: o tempo e esforço necessário para entregar, manter ou estender o software é diretamente relacionado a clareza do código [PP10]. O excesso de complexidade diminui o valor do produto, pois a complexidade torna o software mais suscetível a erros, além de torná-lo mais difícil de ser alterado no futuro [Bec06]. No seu livro Clean Code [Mar08], Martin fornece diretrizes para escrever um código "limpo", tornando-o mais simples e legível.

\section{3 - Crie conhecimento}

O desenvolvimento de software é similar ao desenvolvimento de novos produtos, pois é uma atividade que cria algo único para o cliente [SB02]. Larman sugere que, ao contrário do cenário numa linha de produção em massa, o software não é algo previsível ou imune a mudanças [Lar04]. Desenvolver é como criar uma receita, um processo de aprendizado, que envolve tentativas e er$\operatorname{ros}[\mathrm{PP} 03]$.

Organizações que têm se destacado no desenvolvimento de produtos compartilham um traço comum: elas criam conhecimento e tornam-o acessível a toda a organização em uma forma concisa. Essas companhias não apenas tornam acessível o conhecimento explícito, como encontram formas de compartilhar o conhecimento tácito [NT95].

Nonaka sugere que as empresas utilizem metáforas e encorajem o diálogo para tornar o conhecimento tácito explícito [GB93]. Beck sugere que a linguagem utilizada deve ser entendida tanto pelas pessoas técnicas, quanto pelas pessoas de négocio [Bec99]. Isso pode ser obtido através de uma metáfora comum que relaciona abstrações do sistema com objetos de um certo domínio, existente no mundo real. Sato [Sat07] afirma que essa prática estava bastante alinhada com um padrão descrito por Ward Cunningham, que ficou conhecido como "Sistema de Nomes" [Cun]. Mais recentemente, o uso dessa linguagem ubíqua para representar conceitos de domínio no código-fonte ficou popularizada com a técnica de modelagem definida por Eric Evans, conhecida como Domain Driven Design [Eva03]. 
No desenvolvimento de software, duas práticas se destacam em criar conhecimento:

- Desenvolvimento iterativo: O desenvolvimento iterativo tem se mostrado como uma das formas mais eficientes de se criar conhecimento, pois permite que a equipe aproveite o conhecimento criado durante as iterações [LB03]. No entanto, o desenvolvimento iterativo pode tornar o código do sistema muito complexo, aumentando o custo para acrescentar mudanças. O uso constante de refatoração é indicado para diminuir a complexidade do código e diminuir o custo para acrescentar mudanças [PP06].

- Set-Based Design: é uma abordagem exploratória na qual conjuntos de soluções são desenvolvidos simultaneamente, esta abordagem é recomendada quando decisões irreversíveis devem ser tomadas. Essa prática será explicada em maiores detalhes na Subseção 3.1.2.

\section{4 - Adie comprometimentos}

No seu artigo Delaying Commitment [Thi02], Thimbleby observa que tomadas de decisões prematuras é um modo falho de planejamento, pois restringe o aprendizado, agrava os impactos de defeitos, limita a utilidade do produto e aumenta o custo de mudanças.

Segundo Ballard [Bal00], o adiamento de comprometimentos é uma estratégia para evitar decisões prematuras e para gerar mais valor ao projeto. Práticas de desenvolvimento que possibilitam decisões tardias são efetivas em domínios que envolvem incertezas, como no desenvolvimento de software [McC93, CKI88, Ric07, $\mathrm{KMWF}^{+}$01], pois permitem obter flexibilidade durante o processo de desenvolvimento do produto.

Construir flexibilidade para acomodar mudanças arbitrárias é muito caro e pode ser um desperdício. Segundo Johnson [Joh02], 45\% das funcionalidades implementadas num sistema típico não são utilizadas nunca e $19 \%$ são raramente utilizadas. A melhor estratégia é evitar generalizações desnecessárias e fazer com que o sistema seja flexível apenas nas áreas mais propícias à mudança [PP06]. No desenvolvimento de software, duas abordagens ajudam a obter flexibilidade durante o desenvolvimento:

- Refatoração: é uma técnica sistemática para reestruturar o código existente, alterando sua estrutura interna, porém mantendo seu comportamento externo $\left[\mathrm{FBB}^{+} 02\right]$. O objetivo é sempre tornar o código e o design mais simples, legível, limpo e preparado para mudanças. Ao diminuir o custo de mudanças, tornando a adição de funcionalidade tão simples quanto possível, a refatoração permite que os desenvolvedores aguardem que uma funcionalidade seja necessária para então adicioná-la.

- Set-Based Design: é uma abordagem exploratória na qual conjuntos de soluções são desenvolvidos simultaneamente. Ao invés de tentar prever o futuro escolhendo uma solução no início do desenvolvimento, a equipe explora diversas soluções e elimina, gradativamente, as menos adequadas até que a solução mais adequada seja encontrada. Essa abordagem permite adiar as decisões até o último momento possível (last responsible moment), momento em que a falta de decisão elimina uma alternativa importante [Pop03b]. 


\section{5 - Entregue rápido}

No competitivo e acelerado mercado de desenvolvimento de produtos, velocidade e flexibilidade são essenciais [TN86]. Empresas que competem com base na velocidade, frequentemente, possuem vantagens em relação aos seus competidores, pois possuem um processo com menos desperdício, poucos problemas e um profundo conhecimento das necessidades do cliente [PP06]. Além disso, o desenvolvimento rápido assegura que as necessidades do cliente sejam atendidas prontamente, dando a ele a oportunidade de adiar a tomada de decisão até o momento mais propício [PP03].

Algumas práticas de desenvolvimento ajudam a entregar de forma mais rápida e frequente:

- Folga: um tempo de folga deve ser incluído no planejamento, para que eventuais atrasos não atrapalhem a entrega da iteração ou da release. Quando um sistema está sobrecarregado ocorre um fenômeno chamado thrashing [PP06] que interfere no fluxo de desenvolvimento, fazendo com com que as organizações entreguem menos valor enquanto utilizam mais recursos. Segundo Reinertsen [Rei97], possuir folga é fundamental para evitar que o thrashing ocorra no processo de desenvolvimento. No seu livro Slack [DeM02], DeMarco afirma que possuir folga na organização oferece a ela a capacidade de realizar mudanças, se reinventar e mobilizar recursos para crescer.

- Iteração: uma iteração é um ciclo completo de design-code-verify-release. A cada início de iteração, os membros da equipe se reúnem para: refletir sobre o progresso realizado até o momento, planejar e priorizar as histórias com o cliente, e quebrar cada história em tarefas que serão implementadas durante a iteração. O desenvolvimento iterativo ajuda a melhorar a qualidade do produto final [Coc04] e combate a tendência de um trabalho levar mais tempo do que o esperado [SW07].

- Sistemas Kanban: é uma abordagem que se concentra em criar um fluxo contínuo de trabalho através de pequenos cartões sinalizadores, chamados de kanban. Cada cartão possui uma pequena quantidade de trabalho a ser feita, geralmente, uma pequena história e exemplos claros do que deve ser testado. Os cartões são colocados nos quadros kanban, apresentado na Figura 3.3, indicando em qual etapa de desenvolvimento a atividade está. A quantidade de tarefas em cada etapa do desenvolvimento indica o tamanho da fila.

Todos os Sistemas Kanban foram idealizados de forma a limitar o estoque em processo (WIP - work in process), pois, quanto maior a quantidade de WIP, mais lento é o fluxo do sistema [PP10]. No quadro kanban o limitador de WIP é a quantidade de tarefas em cada etapa.

\section{6 - Respeite as pessoas}

Respeitar as pessoas significa respeitar o intelecto e sua capacidade, dando a elas planos e objetivos justos, e confiando que as equipes podem se auto-organizar para atingir o objetivo. Uma empresa que respeita as pessoas, desenvolve bons líderes e certificam-se de que eles auxiliam a equipe motivando, apoiando e direcionando para que elas alcancem os resultados esperados [Pop02b]. 


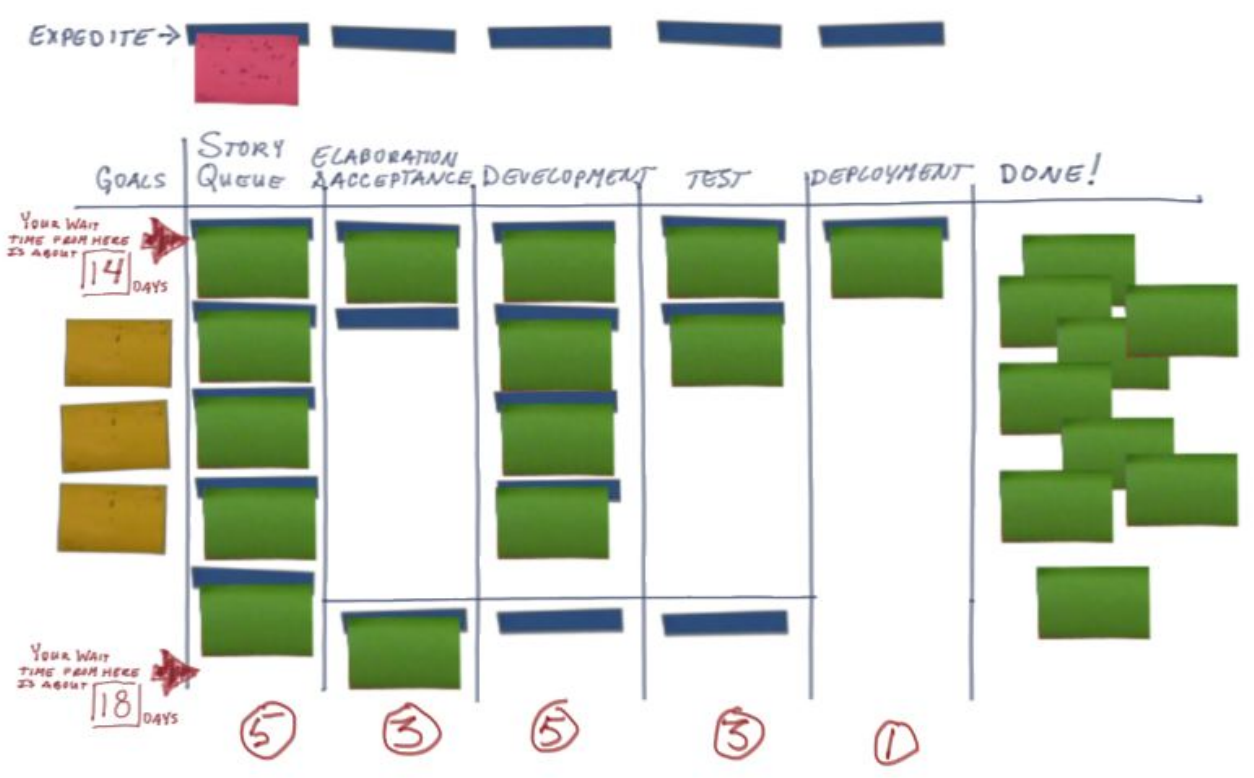

Figura 3.3: Quadro kanban.Fonte: http://www.agileproductdesign.com

Quando mudanças ocorrem muito rapidamente, é necessário trocar a liderança diretiva por uma liderança liberal [PP06]. Na liderança diretiva, o líder determina as providências e as técnicas para a execução das tarefas. Na liderança liberal as pessoas possuem mais liberdade na execução dos seus projetos. Porém para que a equipe se mantenha coesa é necessário que o ambiente dê suporte a elas, permitindo que elas descubram qual a próxima tarefa que deve ser executada, sem a necessidade de um direcionamento do líder.

No desenvolvimento de software, Poppendieck sugere três ferramentas para criar um ambiente no qual as pessoas possuam autonomia [PP06]:

- Quadro Kanban: o quadro kanban é um quadro de tarefas que mostra o progresso das tarefas no fluxo de processo 3.4. Ele será apresentado em mais detalhes na Seção 3.1.2.

- Taskboard: o quadro taskboard mostra o estado atual de todas as tarefas a serem feitas na iteração. Um quadro taskboard simples, apresentado na Figura 3.4, indica quais são as próximas tarefas a serem feitas pela equipe, além de indicar o progresso da equipe;

- Andon: é qualquer dispositivo que torna vísivel os problemas, para que eles possam ser tratados imediatamente. O uso de dois lava-lamp, mostrados na Figura 3.5, para sinalizar o resultado do build de um sistema é um exemplo de sistema andon no desenvolvimento de software.

- Dashboard: é qualquer dispositivo visual que indica o progresso do trabalho. Um observador interessado deve ser capaz de ter uma ideia da evolução do projeto apenas andando pela área de trabalho. Alguns exemplos de instrumentos para espalhar essas informações, chamados de radiadores de informação por Cockburn [Coc06], são: o burn-down chart proposto pelo 


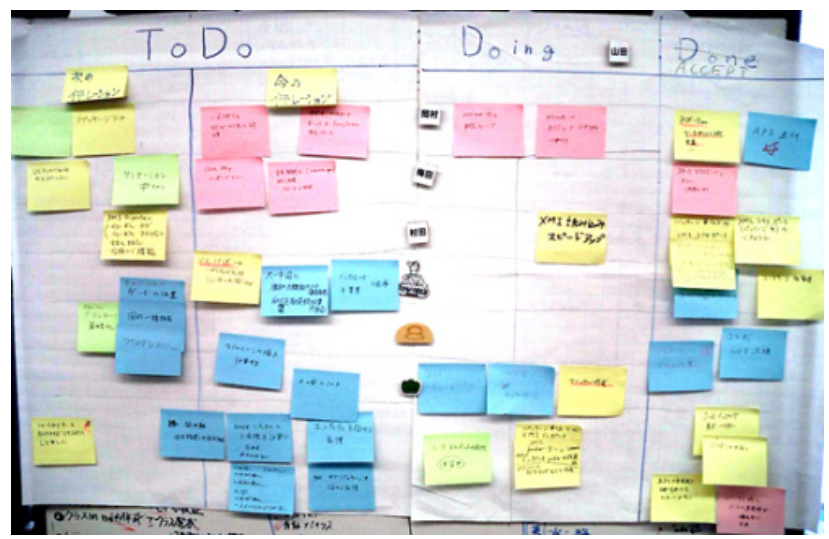

Figura 3.4: Quadro Kanban que mostra o estado atual de todas as tarefas a serem feitas na iteração. As tarefas são representadas por cartões (Post-It), o quadro é separado em categorias que indicam o estado do desenvolvimento da tarefa: A fazer (ToDo), Fazendo (Doing) e Feito (Done). Fonte: http://www.infoq.com/ articles/agile-kanban-boards
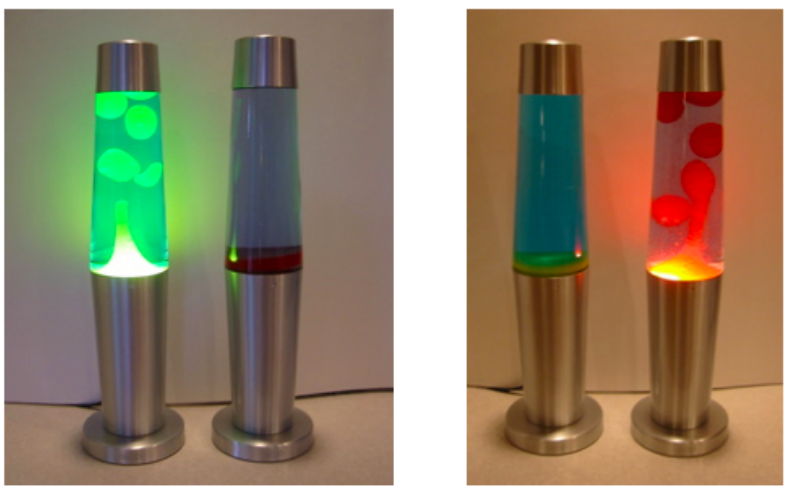

Figura 3.5: Lava Lamp. Fonte: http://www.pragmaticautomation.com

Scrum [SB02,SC04] para acompanhar a velocidade da equipe, gráficos de testes de aceitação, gráficos que mostram a quantidade de defeitos no produto, etc....

\section{7 - Otimize o todo}

Uma organização lean otimiza todo o fluxo de valor, desde o momento em que recebe um pedido para atender a necessidade do cliente até o momento em que o software é entregue. Quando uma organização se concentra em otimizar as partes sem possuir uma visão global é comum que o fluxo de valor sofra [PP06].

A maioria das teorias de gerenciamento de projetos de software são baseadas em teorias de decomposições: decomponha o problema em pequenas partes e melhore cada uma delas isoladamente. Segundo Skyttner [Sky01], quando cada parte do sistema é melhorada independentemente, o sistema como um todo é sub-otimizado. A melhor forma de encorajar colaboração e evitar subotimizações é fazer com que as pessoas sejam avaliadas de acordo com sua esfera de influência, ao invés de apenas a área que ela controla [ADL96].

No desenvolvimento de software algumas práticas ajudam a dar uma visão global: 
- Value Stream Map: é um diagrama que mapeia o fluxo de trabalho, o fluxo tem início quando uma necessidade do cliente é identificada e termina quando ela é atendida. Através do Value Stream Map é possível identificar as etapas do processo que podem ser melhoradas para aumentar o fluxo.

- Story Mapping: é uma ferramenta que identifica o conjunto de usuários e seus respectivos objetivos fornecendo uma visão geral do sistema [Pat08]. O User Story Map, apresentado na Figura 3.6, organiza as histórias dos usuários em um modelo que ajuda a entender as funcionalidades do sistema, facilitando a identificação de possíveis omissões e falhas no backlog. No seu artigo It's All in How you Slice It [Pat05], Patton introduz o conceito de Story Mapping, ensinando como utilizá-lo.

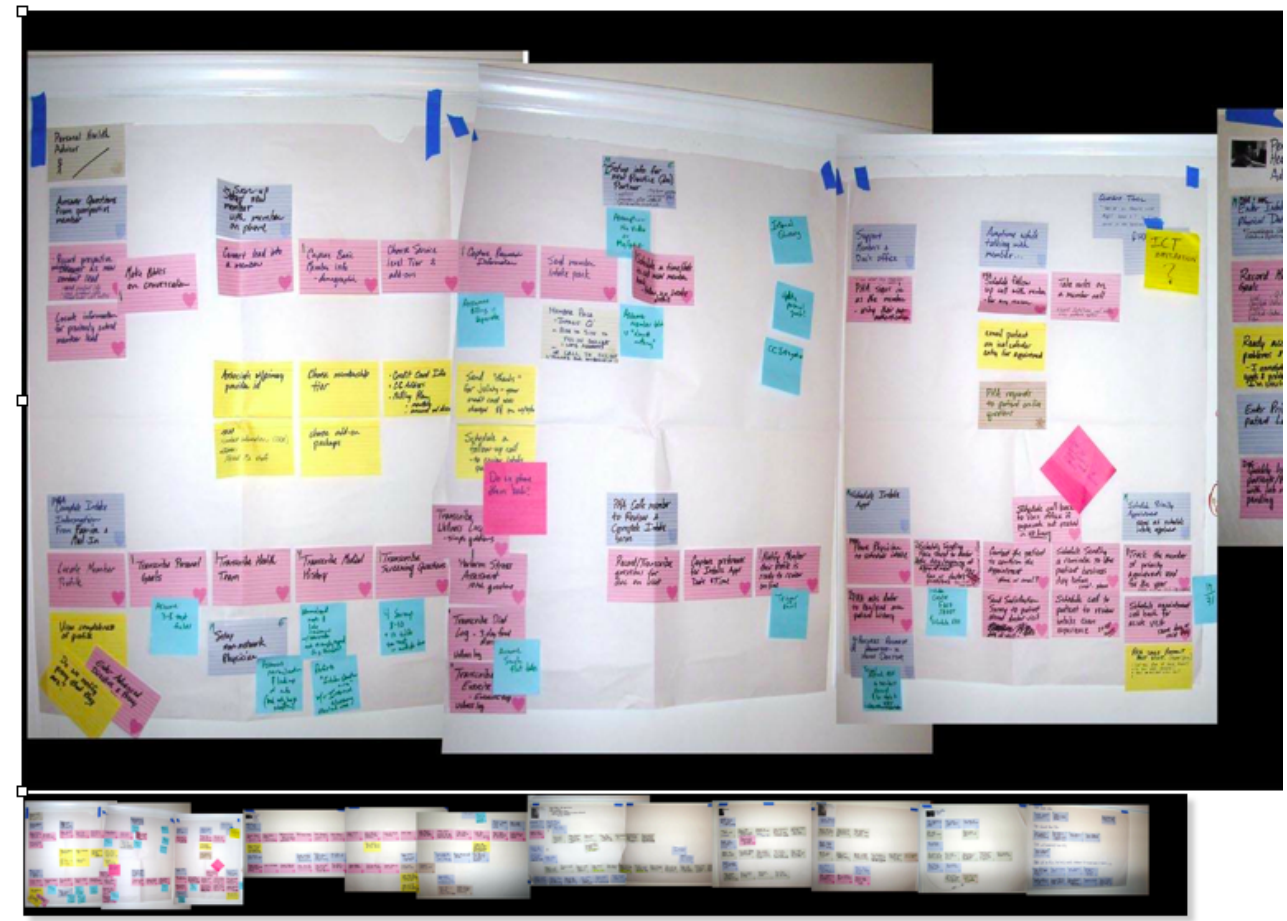

Figura 3.6: Quadro Story Map.Fonte: http://www.agileproductdesign.com

\subsubsection{Práticas}

\section{Set Based Design}

No desenvolvimento de software, é comum que o software evolua conforme o usuário vê o sistema sendo implantado e em funcionamento. Construir flexibilidade para acomodar mudanças arbitrárias é muito caro e pode ser um desperdício. Segundo Johnson [Joh02], 45\% das funcionalidades implementadas num sistema típico nunca são utilizadas e 19\% são raramente utilizadas.

O desenvolvimento ágil utiliza o desenvolvimento iterativo e incremental evitando generalizações desnecessárias e construindo um sistema flexível a mudanças. Para minimizar o custo com mudanças 
desnecessárias no futuro, os desenvolvedores devem sempre implementar o design mais simples - e não o mais simplista - com o mínimo necessário da complexidade e flexibilidade para atender às necessidades de negócio atuais [Sat07].

No entanto, quando decisões irreversíveis ou de alto-impacto devem ser tomadas, Poppendieck recomenda o uso da técnica Set Based Design [PP06]. Conforme visto na Seção 2.1.4, o Set Based Design é uma abordagem exploratória na qual diversas soluções para um mesmo problema são criadas e, gradativamente, as soluções inferiores são eliminadas até que uma solução adequada seja encontrada ou até que o prazo final para a criação de uma solução esgote (neste caso, a solução mais adequada no momento é escolhida).

Uma abordagem comum é criar múltiplas soluções com diversos níveis de complexidade: uma solução simples que será finalizada antes do prazo e outras mais complexas, porém mais eficazes, que se ficassem prontas antes do prazo seriam a melhor opção. No livro Implementing Lean Software Development [PP06], Poppendieck relata o uso da técnica Set Based Design em um caso no qual o gerente encontrava-se em um dilema: desenvolver um software simples, mas não muito eficaz, para correção de olhos vermelhos em fotos ou desenvolver um software complexo que corrigiria melhor as fotos, mas poderia não estar pronto até o lançamento do produto. Segundo a equipe de marketing, a inclusão de correção de olhos vermelhos era um grande diferencial e alavancaria as vendas dos produtos. Nessa ocasião, Poppendieck sugeriu ao gerente que ele desenvolvesse as duas alternativas, para isso ele deveria argumentar aos superiores que uma solução estaria pronta antes do lançamento do produto e que talvez, uma outra solução melhor estaria pronta, mas se não estivesse, ela estaria pronta para o próximo lançamento.

\section{Relatório A3}

As equipes ágeis são encorajadas a refletir sobre como se tornar mais eficientes, refinando e ajustando seu comportamento apropriadamente. Uma prática comumente utilizada nos métodos ágeis para melhorar o processo é a Retrospectiva. A Retrospectiva é uma reunião realizada ao final de cada iteração na qual o processo de desenvolvimento é avaliado: a equipe discute as lições aprendidas com a experiência e planeja as mudanças para o próximo ciclo de desenvolvimento [Ker01]. Existem diversos formatos para as reuniões de Retrospectiva [DLS06] sendo que na forma mais comum a equipe discute "O que funcionou bem?", "O que podemos melhorar?" e "Quais problemas nos preocupam?". Normalmente, ao fim da reunião, a equipe terá um conjunto de ações em cada uma das categorias acima e poderá priorizá-las e escolher as mais importantes para implementar na próxima iteração.

Um problema típico nas retrospectivas é que elas nem sempre progridem além da identificação do problema. A resolução de problemas demanda tempo, mas é essencial para que a melhoria ocorra e, portanto, não deve ser tratada como um atividade periférica. Criar soluções aleatoriamente até que o problema seja resolvido provavelmente não irá sanar a causa do problema. Além disso, criar soluções aleatórias não ajuda no principal objetivo que é aprender sobre o processo. O aprendizado do processo possibilita que a equipe alcance melhores resultados através da melhoria da equipe em identificar problemas, criar contramedidas e ajustar o processo. 
Uma boa ferramenta para auxiliar no processo de resolução de problemas e aprendizado é o relatório A3. Um relatório A3 captura não apenas o processo de resolução do problema, mas também a sua lógica. As Figuras 3.7 e 3.8 apresentam um Relatório A3 utilizado para explorar o problema de lançamentos tardios em uma empresa de jogos.

Nele é possível observar as principais características de um relatório A3:

- Proprietário, Mentor e Data: o Relatório A3 é produzido pelo proprietário, sendo ele o responsável por implementar as contramedidas. O mentor é responsável por auxiliar o proprietário e criticar o relatório para que ele seja melhorado;

- Tema e Contexto: o Tema é o título do relatório e sugere qual problema sendo tratado. O Contexto mostra o porquê do problema ser relevante, expondo de forma sucinta o impacto dele na organização;

- Situação atual: a Situação atual apresenta detalhadamente e quantitativamente o estado atual da organização, especificando o local em que o problema ocorre. O objetivo é possuir uma base de comparação para as contramedidas implementadas;

- Objetivo da melhoria: o Objetivo da melhoria apresenta o que o Proprietário deseja alcançar idealisticamente. O Mentor é responsável por garantir que a hipótese do Proprietário é plausível e que idealmente as pessoas envolvidas na mudança estejam de acordo;

- Causa do problema: nesse passo, a causa do problema é identificada. Algumas técnicas geralmente utilizadas são: cinco porquês (Seção 3.1.2), diagrama de fishbone e árvore da realidade atual;

- Contramedidas: a Contramedida apresenta os diversos experimentos propostos para eliminar o problema raiz. Cada experimento possui uma breve descrição e seu resultado esperado;

- Resultados: o Resultado apresenta os resultados obtidos dos experimentos propostos. Quando o resultado é diferente do esperado, uma análise da diferença da expectativa deve ser apresentada. Além disso, algumas métricas devem ser sugeridas para avaliar se o problema foi resolvido;

- Próximos passos: nesse passo, algumas ideias e/ou experimentos são propostos, dando continuidade ao processo de melhoria da equipe.

\section{Mapa de Fluxo de Valor}

O Mapa de Fluxo de Valor é uma ferramenta que auxilia a identificar oportunidades de melhorias em um processo. No desenvolvimento de software, o Mapa de Fluxo de Valor geralmente tem início quando o cliente requisita um produto ou uma funcionalidade, e termina quando a solução é colocada em produção (resolvendo o problema do cliente) [PP06]. Através de uma visão geral do processo, é possível observar as atividades que demoram para iniciar (filas) e as atividades que voltam etapas no processo (atividades incompletas ou com defeitos). 


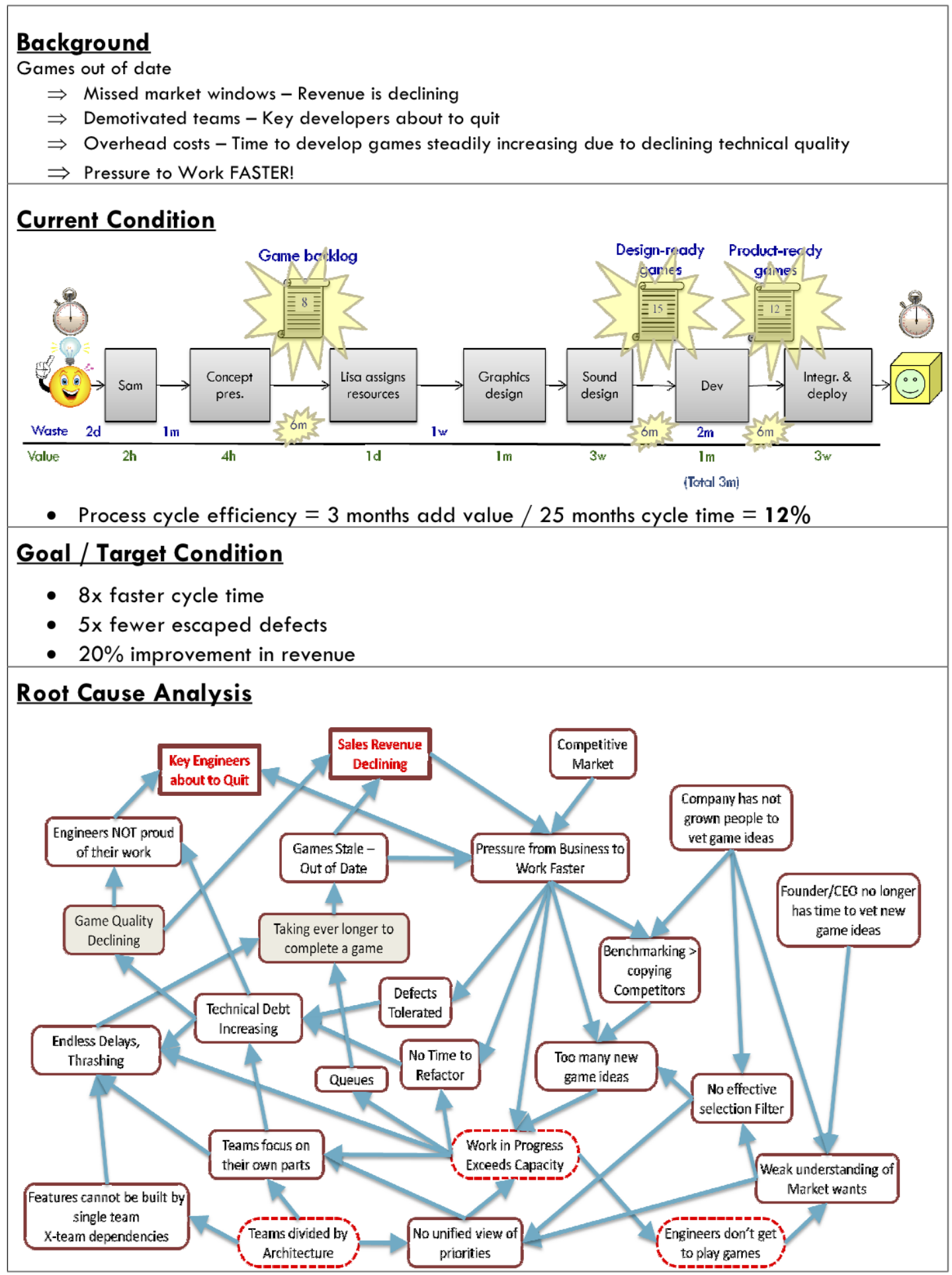

Figura 3.7: Lado esquerdo do Relatório A3. Exemplo criado por Tom Poppendieck e Henrik Kniberg para Deep Lean 2009 em Stockholm e Agile 2009 em Chicago. O exemplo foi baseado em um caso real. Fonte: http://www.crisp.se/lean/a3-template 


\section{Owner: Lisa \\ Mentor: Heinrich \\ Date: 18 May 2009}

\section{Countermeasures}

1. Cross Functional Teams - Graphics design through deployment

$\checkmark$ Predict 2x Faster Delivery

$\Rightarrow$ End dependencies - now spend $75 \%$ of time waiting/negotiating

2. Abandon all but most promising 3 games in each queve. Do ONE game per cross functional team at a time.

$\checkmark 4 \mathrm{x}$ faster delivery from reduced task switching

$\checkmark$ Eliminating queves will cut 1.3 years from schedule

3. Engage developers in playing games and selecting ideas

$\checkmark 30 \%$ more profit to par with best competitor

$\Rightarrow$ Improved filtering on which games to develop

$\Rightarrow$ More fun games, more popular

\section{Confirmation (Results)}

1. Cross Functional Teams

$\Rightarrow$ Half as much time waiting

2. One game at a time

$\Rightarrow$ Queves eliminated, time to complete game is 4 months (6x)

$\Rightarrow$ Technical Debt decreasing - Escaped defects down by $2 x$ so far

3. Engage developers in playing games and selecting ideas

$\Rightarrow$ One team taking time to play is producing more innovative games.

$\Rightarrow$ Impact on profit is TBD.

\section{Follow-up}

1. Consider more cross training of team members to reduce waiting for expertise

2. Reduce difficulty of integration and deployment steps

3. Improve processes for generating and selecting game ideas

a. Recruit talent if identifiable/available

b. Improve skills/process of best people already in company

c. Broaden both participation in selection and game playing experience of everyone in the company.

4. Continue improvement of reused game components/engines to improve development throughput and reduce defects.

Figura 3.8: Lado direito do Relatório A3. Exemplo criado por Tom Poppendieck e Henrik Kniberg para Deep Lean 2009 em Stockholm e Agile 2009 em Chicago. O exemplo foi baseado em um caso real.

Fonte: http://www.crisp.se/lean/a3-template

O Mapa de Fluxo de Valor deve refletir a visão do cliente sobre o processo. Do ponto de vista dele, atividades que demoram para iniciar são quase sempre desperdício, pois para ele, o importante é que um pedido feito por ele seja atendido da forma mais rápida possível.

Poppendieck sugere os seguintes passos para criar um Mapa de Fluxo de Valor [PP06]: 
1. Selecione um processo para criar o Mapa de Fluxo de Valor. A ideia é selecionar o processo inteiro e não apenas um único evento. No desenvolvimento de software, isso pode ser difícil, pois diversos projetos podem estar sendo produzidos simultaneamente e/ou atividade diferentes podem ocorrer no mesmo processo. Uma alternativa, é selecionar um processo que represente grupos de projetos similares. Por exemplo, escolher um processo que representa projetos de médio porte ou criar um Mapa de Fluxo de Valor para diferentes tipos de atividades, e.g. atividades de alta prioridade, baixa prioridade, etc...;

2. Decida quando o processo deve começar e terminar de ser avaliado. No desenvolvimento de software, o Mapa de Fluxo de Valor geralmente inicia quando o cliente faz o pedido e termina quando a solução é colocada em produção;

3. Liste as principais atividades para a criação do produto;

4. Quantifique o tempo médio gasto para cada atividade;

5. Quantifique o tempo médio gasto entre cada atividade;

6. Calcule o tempo total do ciclo de desenvolvimento: soma do tempo gasto de cada atividade + tempo gasto entre cada atividade;

7. Calcule o tempo total de atividades que agregam valor: soma do tempo gasto de cada atividade;

8. Calcule a eficiência do processo:

$$
\frac{\text { tempo total de atividades que agregam valor }}{\text { tempo total do ciclo de desenvolvimento }}
$$

\section{Analise os resultados.}

A Figura 3.9 apresenta um exemplo de Mapa de Fluxo de Valor. Nele é possível observar quanto tempo é desperdiçado com as atividades esperando para serem iniciadas (Game Backlog, Design-Ready games, Product-Ready games).

\section{Sistemas Kanban}

No desenvolvimento ágil de software é comum a prática de utilizar cartazes e gráficos para espalhar informações sobre o progresso da equipe. Em particular, o mural de tarefas que mostra o progresso delas é conhecido como Quadro de Tarefas ou Quadro Kanban. Quando o Quadro Kanban é utilizado para guiar o desenvolvimento através do controle do fluxo de tarefas, considera-se que está sendo utilizado um Sistema Kanban.

Um Sistema Kanban é baseado em duas ideias simples [Kni10]. O WIP deve ser limitado e uma tarefa nova só deve começar a ser executada quando existe capacidade disponível. Nesse quadro, o kanban atua como um sinalizador indicando quando uma tarefa pode começar. O quadro é construído de forma que o kanban possa simular o progresso da tarefa nas diferentes etapas de 


\section{Current Condition}

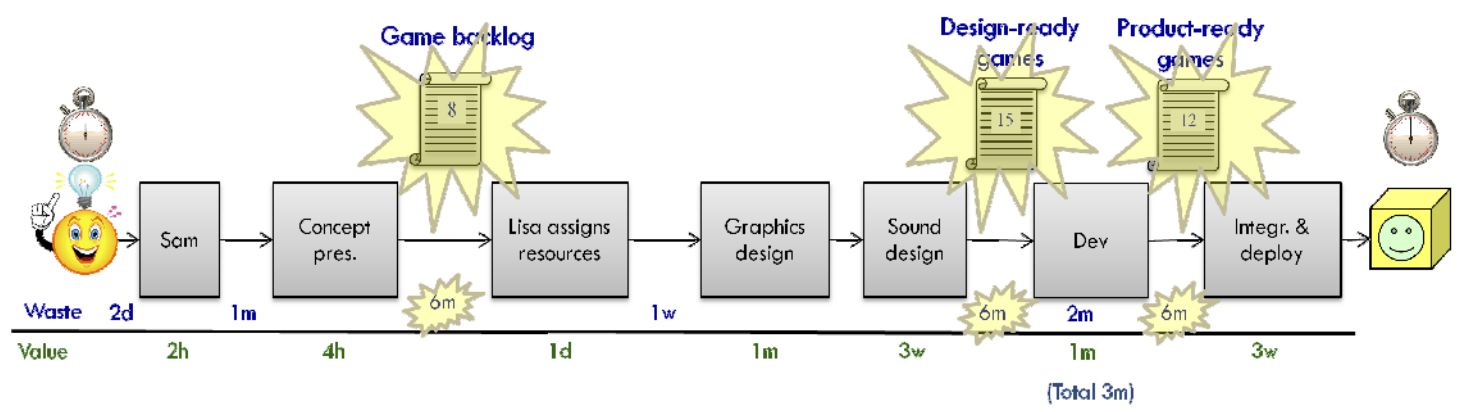

- Process cycle efficiency $=3$ months add value $/ 25$ months cycle time $=12 \%$

Figura 3.9: Exemplo de caso real retirado do Relatório A3 da Figura 3.7.

desenvolvimento. Durante a sua criação, o primeiro passo é desenhar o Mapa de Fluxo de Valor evidenciando todas as etapas essenciais ao desenvolvimento do produto. Para cada etapa identificada uma coluna é criada, indicando a quantidade máxima de tarefas que podem ser realizadas simultaneamente nela. Após a criação do quadro, é importante definir regras para mover as tarefas entre as etapas. A Figura 3.10 apresenta um exemplo de Quadro Kanban.

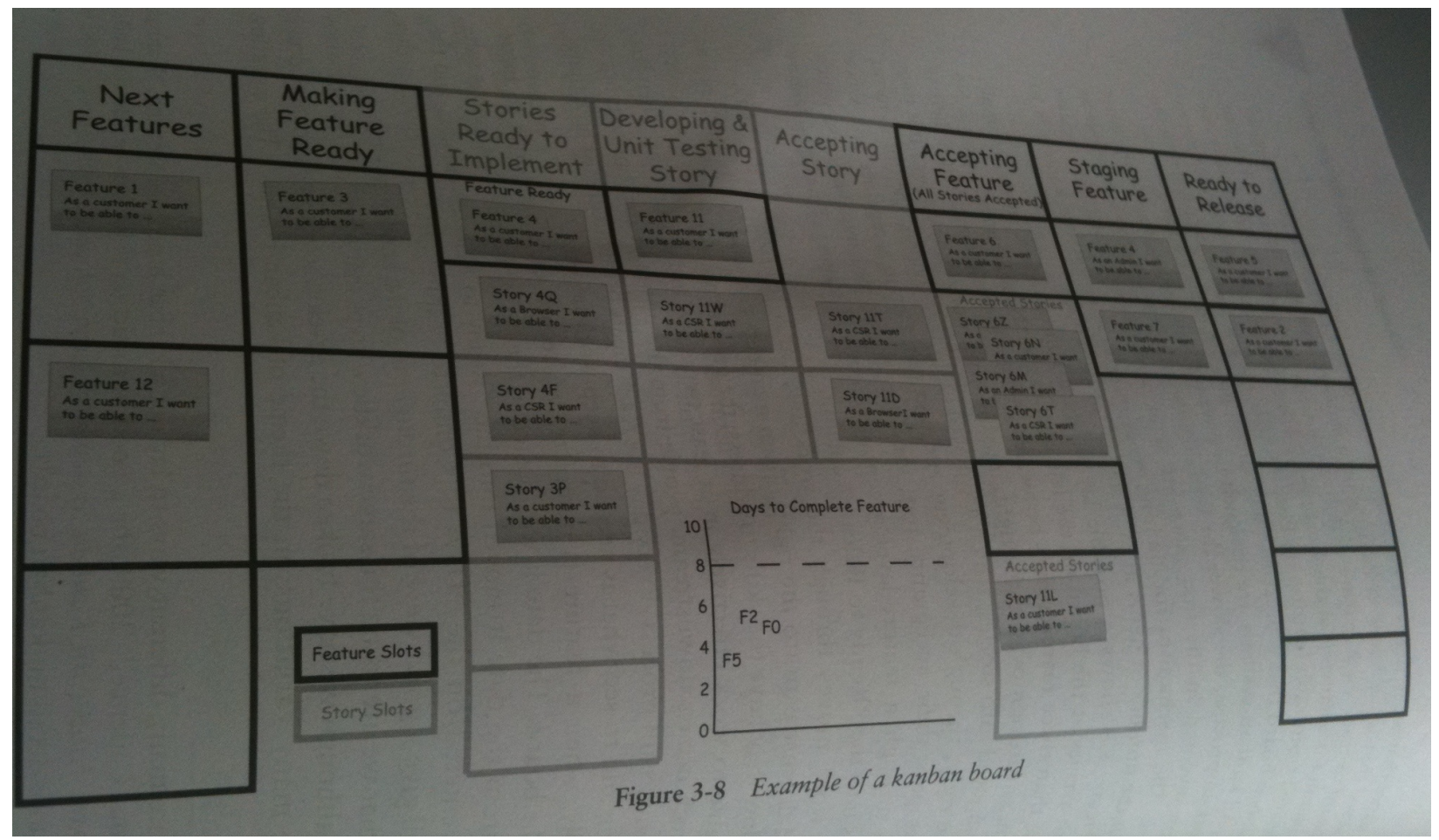

Figura 3.10: Quadro Kanban. Os quadrados brancos representam a quantidade máxima de tarefas que podem ser feitas simultaneamente em cada etapa.

Fonte: Leading Lean Software Development [PP10]. Mary and Tom Poppendieck.

O Sistema Kanban e o Desenvolvimento Iterativo são duas abordagens distintas para gerenciar o fluxo de desenvolvimento de software. Embora ambas sejam excelentes para promover um fluxo 
contínuo e rápido de desenvolvimento de tarefas, elas apresentam algumas diferenças significativas que serão discutidas a seguir.

1. Trabalho em equipe

Em um desenvolvimento iterativo as equipes devem ser multi-disciplinares [BA04,SB02], com todas as habilidades necessárias para o sucesso do projeto. Nessas equipes, todos trabalham num espírito de contribuição para a equipe, visando o bom andamento do projeto [Kni10].

Em um Sistema Kanban as equipes não precisam ser multi-disciplinares. As pessoas geralmente trabalham na sua área, sendo responsáveis por trabalhar nas tarefas que recebem até que elas estejam prontas para serem passadas para a próxima etapa [PP10].

\section{Tamanho das tarefas}

No desenvolvimento iterativo as Histórias e tarefas escolhidas devem ser estimadas para que possam ser implementadas em uma iteração (ver Figura 3.11). Se uma História é muito grande para ser feita em uma iteração, ela deve ser quebrada em outras Histórias ou tarefas para que possa ser implementada.

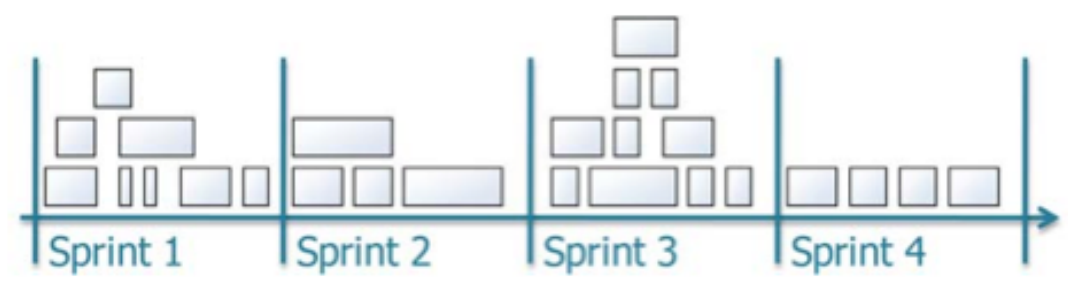

Figura 3.11: No desenvolvimento iterativo, as Histórias devem ser quebradas para que possam ser implementadas em uma iteraçao.

Fonte: Kanban and Scrum: making the most of both [Kni10]. Henrik Kniberg \& Mattias Skarin

A abordagem Kanban tenta minimizar o lead time e nivelar o fluxo. Indiretamente, ele incentiva que as tarefas sejam relativamente pequenas. No entanto, não existe uma regra explícita sobre o tamanho de uma tarefa. Em um mesmo quadro pode existir uma tarefa que pode demorar meses e outras que podem demorar dias (ver Figura 3.12).

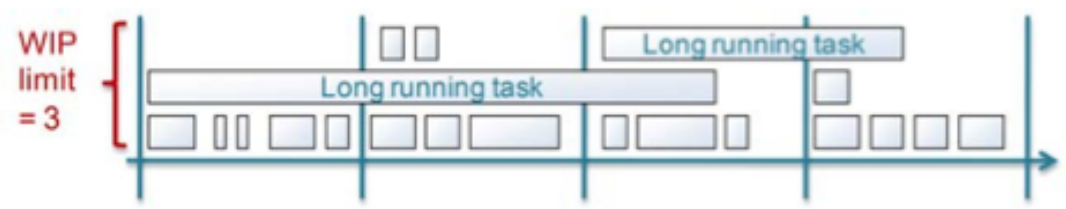

Figura 3.12: No Kanban, as atividades podem se prolongar por diversos meses. Fonte: Kanban and Scrum: making the most of both [Kni10]. Henrik Kniberg \& Mattias Skarin

O Kanban é recomendado em ambientes em que é difícil quebrar uma funcionalidade em diversas Histórias para que elas possam ser implementadas em uma iteração ou em ambientes em que é mais fácil não estimar uma tarefa. 


\section{Cadência}

O desenvolvimento iterativo possui um ritmo constante e sustentável através de ciclos constantes de entregas de funcionalidades. Esse ritmo constante é dependente da Velocidade que informa a equipe e o cliente da capacidade de entregar software funcionando. Um time estabilizado, durante um mesmo projeto e com todos os recursos necessários disponíveis tende a aumentar sua velocidade durante um certo tempo (geralmente no início), até atingir um patamar, onde ela se estabiliza [Sat07].

Embora Sistemas Kanban não prescrevam ciclos de entrega, é comum a criação de ciclos de entregas regulares - por exemplo, uma vez por dia/semana/mês - nas quais as atividades que estão prontas são colocadas em produção.

\section{Capacidade}

No desenvolvimento iterativo é comum o uso da métrica Velocidade. A Velocidade é uma métrica de acompanhamento muito útil para a equipe conhecer seu limite e sempre conseguir atingir o objetivo de cada iteração. A Velocidade informa a equipe e o cliente da capacidade de entregar software funcionando num ritmo constante e sustentável [Sat07].

Em Sistema Kanban utiliza-se a métrica de Tempo Médio de Ciclo (Cycle Time). O tempo de ciclo é calculado de forma objetiva através da medição do tempo que uma atividade leva para passar pelo Mapa de Fluxo de Valor do sistema. O tempo médio de ciclo tende a diminuir quando o sistema trabalha com atividades pequenas e quando o sistema não é sobrecarregado. Se o tempo médio de ciclo se estabilizar, isso não significa que a equipe chegou ao valor ótimo. Ela deve estar constantemente desafiando os padrões atuais para encontrar formas de reduzir o tempo médio de ciclo [PP06].

\section{Cinco porquês}

O Cinco porquês é um método que utiliza a pergunta "por quê?" para explorar as relações de causa e consequência de um problema com o objetivo de identificar a causa raiz dele.

A Tabela 3.2 apresenta um exemplo do uso da técnica Cinco porquês para explorar um típico problema no desenvolvimento de software.

\subsubsection{Formas de adoção}

Adotar a filosofia Lean tem se mostrado um desafio para diversas empresas. Embora muitas empresas tentem a adoção, poucas realmente obtém sucesso [Bal05]. A principal razão para o fracasso da adoção é que muitas empresas reduzem os conceitos de Lean ao uso direto de práticas e ferramentas. Um dos problemas dessa forma de adoção é que práticas são boas apenas em determinados tipos de contexto, e portanto, uma mudança no contexto ou no objetivo pode transformar uma prática boa em uma prática ruim. Um outro problema, é que essa forma de adoção ignora a essência de Lean: comprometimento em melhorar as pessoas e promover uma cultura de melhoria contínua [Hin06]. 


\begin{tabular}{ll} 
& Problema \\
\hline Por quê? & Ao final da iteração as histórias não estão finalizadas. \\
Por quê? & Porque nós subestimamos quanto tempo as histórias demorariam. \\
Por quê? & Porque as histórias escolhidas eram muito complexas. \\
Por quê? & $\begin{array}{l}\text { Porque José não dividiu a história em pedaços menores para que nós con- } \\
\text { seguíssemos entender. }\end{array}$ \\
Por quê? & $\begin{array}{l}\text { Porque José não sabe o que nós precisamos - ou porque é muito difícil } \\
\text { dividir a história em pedaços menores. }\end{array}$ \\
Por quê? & $\begin{array}{l}\text { Porque nós não possuímos um critério de pronto para iniciar o desenvolvi- } \\
\text { mento/ os desenvolvedor não estão trabalhando junto com José para dividir } \\
\text { as histórias em pedaços menores. }\end{array}$
\end{tabular}

Tabela 3.2: análise do problema através do Cinco Porquês. Referência: Leading Lean Software Development [PP10]

Ballé [Bal05] sugere que para uma empresa obter sucesso durante a adoção da filosofia Lean, é necessário uma mudança radical na mentalidade e atitude dos envolvidos. Mudar a mentalidade de uma empresa é uma tarefa árdua. Muitas vezes, mesmo com um grande esforço dos líderes, o objetivo não é alcançado. Christensen et al. [CMS06] identificou dois passos necessários para que mudanças organizacionais ocorram: acordo entre os envolvidos e crença sobre causa e consequência de suas ações.

O primeiro passo, acordo entre os envolvidos, avalia o nível de concordância sobre qual é o objetivo dos envolvidos: resultados esperados, valores e prioridades, e quais concessões os envolvidos se comprometem a fazer para atingir o objetivo esperado. O segundo passo, crença sobre causa e consequência de suas ações, avalia a concordância sobre como deve ser feita a mudança: quais ações serão executadas e quais são os resultados esperados. Quando as pessoas envolvidas na mudança possuem um entendimento comum da causa e consequência de suas ações, elas geralmente concordam sobre quais processos devem ser adotados durante a transição [CMS06].

Para auxiliar na discussão das crenças sobre as causas e consequência das atitudes dos líderes, Poppendieck \& Poppendieck criaram algumas perguntas que analisam os principais pontos de discórdia: forma de controlar custos, opiniões sobre plano e planejamento, alocação eficiente de trabalho, propósito de padronizações e melhor forma de alcançar os resultados. A seguir as perguntas criadas por Poppendieck \& Poppendieck serão apresentadas [PP10]:

1. A atual economia de mercado requer uma redução de custo agressiva. Qual a melhor forma para reduzir custos?

Uma resposta comum para essa pergunta é "reduzir os custos de cada departamento". Apesar dessa abordagem ser fácil de ser aplicada e produzir resultados rápidos ela não é uma abordagem adequada a longo prazo. Isso acontece porque essa abordagem parte da premissa de que otimizar cada parte do sistema faz com que o sistema como um todo fique otimizado. Segundo Goldratt [Gol90], essa premissa é totalmente equivocada e é uma das principais 
causas do desempenho ruim das empresas.

Uma abordagem preferível é "reduzir os custos entre os departamentos", considerando a empresa como um todo. Drucker observa que essa abordagem é melhor que a abordagem tradicional e obtém resultados 25 a $30 \%$ melhores.

2. Qual é o seu ponto de vista sobre comprometer-se a um plano e cumprir o compromisso?

A resposta comum para essa pergunta é que o plano é o compromisso. Muitas pessoas acreditam que previsibilidade é resultado de seguir um plano. Essa hipótese, vem da premissa que os planos sempre estão corretos. No entanto, a criação de um plano realístico é extremamente difícil, pois fatores como tempo e custo de desenvolvimento para uma determinada funcionalidade estão sujeitas a um alto grau de incerteza [LM08].

Uma abordagem preferível é admitir que planos são apenas rascunhos, e portanto, podem e devem ser adaptados a mudanças conforme a equipe aprende e passa a conhecer melhor o sistema. No desenvolvimento de software, é comum que os requisitos mudem enquanto a implementação ainda está acontecendo. Na medida que os requisitos mudam, eles afetam o plano. Isso significa que o plano deve ser facilmente modificável. Esse é o motivo pelo qual o planejamento é mais importante do que o plano. O conhecimento e insight obtidos durante o planejamento perduram mesmo após a mudança do plano.

3. Qual é o seu ponto de vista sobre todas as pessoas sempre terem trabalho atribuídos?

Uma das grandes diferenças de perspectivas entre os líderes é relacionado a opinião sobre o que envolve uma alocação eficiente de recursos. A resposta comum é de que para possuir uma alocação eficiente de recurso, todos deveriam estar trabalhando na capacidade máxima. Essa hipótese, vem da premissa de que a produtividade decorre do fato de que todos sempre possuem trabalho a ser feito e que uma longa lista de trabalho ajuda os líderes a priorizarem melhor suas decisões e ajuda a manter as pessoas ocupadas.

No entanto, essa visão decorre da tendência natural de acreditar que o desempenho de um sistema é obtido por máximos locais. Como visto na Seção 2.2 e Seção 3.1, essa visão é errônea e prejudicial. Na realidade, utilizar um sistema na capacidade máxima aumenta o tempo de ciclo de desenvolvimento, despesas, variabilidade indesejada e riscos, ao mesmo tempo em que diminui a qualidade, motivação da equipe e tempo para obter feedback [Rei09].

\section{Qual é o propósito de padronização?}

Uma forma comum de caracterizar organizações é classificá-las com base na maturidade. Nesse contexto, é comum que organizações avaliem a maturidade como a capacidade de ser disciplinada e repetível. Para elas a padronização é uma forma de tornar possível que qualquer pessoa possa fazer qualquer trabalho. Nessas organizações normas e padrões são criados por grupos de padronizações que escrevem os padrões a serem seguidos e que não devem ser mudados [PP10]. 
Uma abordagem preferível é entender a maturidade como a capacidade da organização de ser disciplinada e adaptável. Nesse contexto, o propósito da padronização é servir como base para um processo de melhoria. Os padrões são criados pela própria equipe e são a melhor forma da equipe fazer sua tarefa no momento. Quando os padrões não são mudados frequentemente, os esforços de melhoria não estão sendo suficientes.

5. Qual a melhor forma de alcançar os objetivos da empresa?

Alguns líderes acreditam que criar uma meta e torna-lá o objetivo a ser alcançado é a melhor forma da empresa alcançar bons resultados. Para esses líderes, para que o desempenho seja melhorado, deve-se encontrar as métricas corretas e utilizá-las para alavancar os resultados. Em seu livro Measuring and Managing Performance in Organizations [ADL96], Robert Austin traz a sua premissa de que as pessoas irão tentar otimizar as medidas de desempenho a que são submetidas. O problema disto, é que é muito difícil criar medidas de desempenho para tudo o que é importante, e medidas de desempenho parciais possuem uma grande probabilidade de se tornarem medidas de desempenho subotimizadas. Um outro problema frequente é a criação de métricas individuais e bônus para incentivar as pessoas a melhorarem seus desempenhos. No entanto, o uso de bônus individuais desencoraja a colaboração e motiva comportamentos anti-éticos [Pop04].

Segundo Deming, "Se o sistema é estável, não há necessidade de especificar objetivos. Você irá obter o que o sistema consegue entregar. Um objetivo além do esperado não será alcançado de forma alguma" [Dem00]. Dessa forma, a melhor forma de alcançar seus objetivos é melhorando a capacidade da organização em entregar software funcionando.

O alinhamento das perspectivas e atitudes entre os líderes é fundamental para que mudanças organizacionais ocorram, pois as pessoas são muito sensíveis às circunstâncias de seu ambiente. O reforço constante através de expressões verbais ou de comportamento geralmente conduzem a mudanças de atitudes, especialmente quando a pessoa está ciente de qual comportamento deve ser modificado. No contexto de uma adoção da filosofia Lean, a organização deve avaliar se a cultura da organização reforça atitudes da filosofia Lean ou enfraquece-a [PP10].

\subsection{Teoria das Restrições}

A Teoria das Restrições tem sido examinada por diversos praticantes de Métodos Ágeis [Coc06, BA04,PP06, And04b]. Baseada no princípio de que para melhorar o fluxo do processo é necessário ter uma visão global e que "bons resultados globais não são iguais à soma de bons resultados locais", a Teoria das Restrições visa identificar e melhorar os gargalos, locais nos quais pequenas melhorias tem um grande impacto na organização.

Cockburn [Coc06] afirma que um dos aspectos mais interessantes da Teoria das Restrições é a habilidade de criar diferentes soluções em diferentes contextos. A seguir, duas soluções que utilizam a Teoria das Restrições para o desenvolvimento de software serão apresentadas. 


\subsubsection{A Corrente Crítica no desenvolvimento de software}

No desenvolvimento de software, o uso da Corrente Crítica é um assunto controverso entre os praticantes de Métodos Ágeis sendo que a principal diferença está na forma como os planos são criados. Nos Métodos Ágeis, planos detalhados são feitos apenas para a fase atual do projeto. Para fases futuras, os planos são considerados apenas rascunhos que podem se adaptar a mudanças conforme a equipe aprende e passa a conhecer melhor o sistema [Sat07]. Na Corrente Crítica, um plano detalhado que envolve todas atividades e suas dependências é criado no início do projeto.

O problema do plano detalhado é a premissa que todos os requisitos necessários para criar o software são conhecidos antes do início do projeto. No desenvolvimento de software é comum que os requisitos mudem enquanto a implementação ainda está acontecendo. Muitas empresas e equipes de desenvolvimento acreditam que mudanças são indesejáveis pois acabam com todo o esforço gasto no planejamento. No entanto, os requisitos geralmente mudam conforme o cliente vê o sistema sendo implantado e em funcionamento. Poppendieck [PP06] sugere que a principal razão das mudanças no desenvolvimento do software é que o processo de negócio ao qual o software está atrelado evolui constantemente.

A criação de planos confiáveis é uma necessidade até mesmo para praticantes de métodos ágeis. Um plano confiável é benéfico, pois [Coh06]:

- Ajuda a equipe a decidir o que deve ser feito e quanto tempo será necessário até que o produto possa ser entregue ao cliente;

- Transmite expectativas do que pode ser desenvolvido no período. Muitas organizações necessitam dessa informação para desenvolver o planejamento estratégico das atividades;

- Fornece contexto e uma visão geral sobre o que é necessário para alcançar o objetivo final do projeto.

Por outro lado, planejamentos não confiáveis levam a redução da moral, desentendimentos e perda da confiança entre a equipe e o cliente $\left[\mathrm{MGK}^{+} 06\right]$.

A criação de um plano realístico é extremamente difícil, pois fatores como tempo e custo de desenvolvimento para uma determinada funcionalidade estão sujeitas a um alto grau de incerteza [LM08]. Beck sugere proteger o plano das incertezas inerentes das estimativas adicionando ao plano algumas tarefas que podem ser removidas caso atrasos ocorram. Uma outra abordagem, mais comum, é adicionar ao plano um tempo de folga para que eventuais atrasos nas atividades não atrapalhem a entrega. No entanto, é necessário evitar o excesso de tempo de folga nas atividades para que os problemas descritos na Subseção 2.2.4 não ocorram.

No desenvolvimento ágil, o uso da Corrente Crítica não é adequado para planejamento de iterações, pois os problemas que ela soluciona não ocorrem durante uma iteração. Os Métodos Ágeis evitam os problemas combatidos pela Corrente Crítica criando histórias ${ }^{2}$ pequenas que não

\footnotetext{
${ }^{2}$ Segundo Cohn [Coh04], uma boa história agrega valor para o cliente e é independente, negociável, estimável, pequena e testável.
} 
possuem dependências entre si. Enquanto uma história de curta duração minimiza os efeitos da Lei de Parkinson, a independência entre elas permite a compensação de atrasos através do término antecipado de outras tarefas. Por fim, durante uma iteração prazos específicos para cada tarefa são inexistentes, evitando assim, os efeitos negativos da Síndrome do Estudante.

Durante o planejamento do Release ${ }^{3}$ é normal que os requisitos sejam entendidos apenas superficialmente, aumentando os riscos de possíveis erros nas estimativas. Tipicamente um Release é composto por diversos temas ${ }^{4}$ e possui duração de dois a seis meses, cobrindo diversas iterações. Neste tipo de planejamento de alto nível, o uso de buffers para mitigar riscos é uma escolha sábia e a Corrente Crítica se apresenta como uma boa solução para gerenciar os buffers. A seguir um exemplo de como utilizar os conceitos da Corrente Crítica no planejamento de Release será apresentado.

\section{Um exemplo do uso da Corrente Crítica durante o planejamento de release}

A seguir será apresentado um exemplo do uso da Corrente Crítica no desenvolvimento de software. Como base, foi utilizado um exemplo de uso do livro Agile Estimating and Planning [Coh06].

Dave, um contador de uma empresa de médio porte, gostaria de desenvolver um produto que pudesse auxiliá-lo a visualizar os gastos da empresa. Para isso ele contratou uma equipe de desenvolvedores para ajudá-lo nesta tarefa. Após uma explicação de qual seria o produto final, Dave e a equipe se reuniram, escreveram as histórias, estimaram-nas e decidiram que a base do produto seria desenvolvido em quatro iterações. A Tabela 3.3 apresenta os objetivos de cada iteração.

Tabela 3.3: Objetivo das iterações do sistema de visualização de gastos

\begin{tabular}{|c|l|}
\hline Iteração & Objetivo \\
\hline 1 & Importar dados para o sistema \\
\hline 2 & Criar uma forma simples para visualizar os gastos internos da empresa \\
\hline 3 & Criar uma forma simples para visualizar os gastos externos da mercado \\
\hline 4 & Criar novas formas para visualização dos dados \\
\hline
\end{tabular}

Para proteger o plano contra incerteza, é necessário quantificá-la. Uma abordagem comum é estimar a história, atribuindo um valor que reflete a expectativa de trabalho necessário para que a história seja feita. Se quisermos que o plano possua uma confiabilidade de 90\%, uma abordagem inicial seria estimar cada história com uma confiabilidade de 90\%. Desta forma, as tarefas estariam protegidas de eventuais imprevistos. No entanto, como visto na Subseção 2.2.4 essa abordagem apresenta diversos problemas.

Uma outra forma de proteger o plano contra incerteza é utilizar uma abordagem baseada na Corrente Crítica. Para cada história duas estimativas são feitas: uma otimista e outra pessimista. A Tabela 3.4 apresenta as iterações com suas respectivas estimativas. Uma possível esquematização pode ser vista na Figura 3.13. O primeiro número em cada história representa a estimativa otimista, enquanto o segundo representa o tempo de folga, diferença entre a estimativa pessimista e a otimista que é adicionado quando desejamos ter mais confiança de que a tarefa será terminada no tempo

\footnotetext{
${ }^{3} \mathrm{O}$ Release é um plano de alto nível que identifica quando o produto estará disponível no mercado e quais funcionalidades estarão inclusas.

${ }^{4}$ Temas são diferentes de histórias, pois, ao invés de se preocupar com os detalhes, abrangem o todo.
} 
estimado.

Tabela 3.4: Estimativas pessimistas e otimistas da soma acumulada das histórias em cada iteração. A unidade de medida utilizada para a estimativa é a de horas ideais.

\begin{tabular}{|l|c|c|}
\hline Objetivo & Estimativa otimista & Estimativa pessimista \\
\hline Importar dados para o sistema & 5 & 12 \\
\hline $\begin{array}{l}\text { Criar uma forma simples para visualizar os gastos inter- } \\
\text { nos da empresa }\end{array}$ & 6 & 10 \\
\hline $\begin{array}{l}\text { Criar uma forma simples para visualizar os gastos exter- } \\
\text { nos da empresa }\end{array}$ & 5 & 10 \\
\hline Criar novas formas para visualização dos dados & 7 & 15 \\
\hline
\end{tabular}

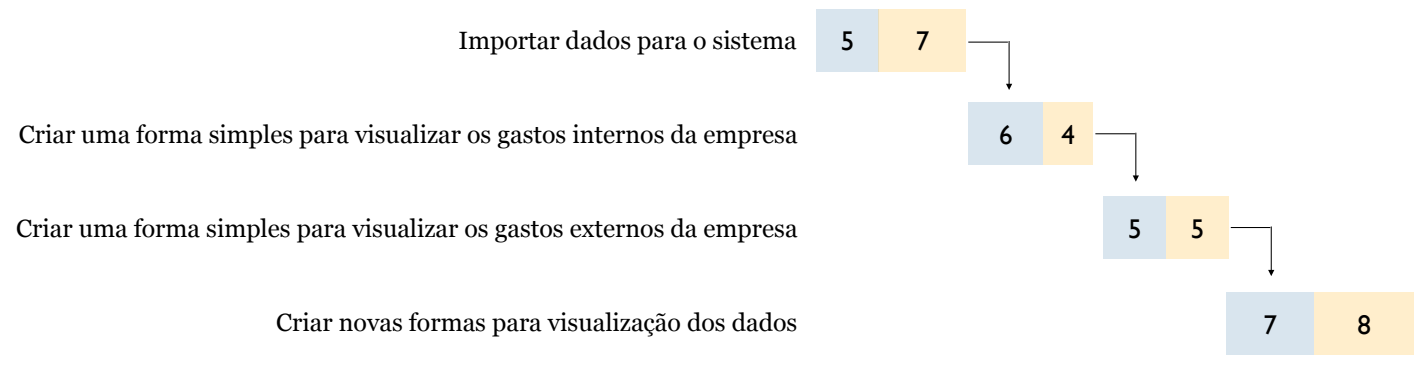

Tempo total: 47

Figura 3.13: Exemplo de um planejamento de release que adiciona em cada atividade tempo de folga.

Adicionar o tempo de folga em todas as atividades estende a duração do projeto desnecessariamente, pois é improvável que imprevistos ocorram em todas as atividades. A abordagem da Corrente Crítica sugere que para gerenciar o projeto, deve-se utilizar as estimativas otimistas e adicionar um buffer compartilhado por todas as atividades que protegerá o plano de eventuais imprevistos. A Figura 3.14 apresenta o planejamento das atividades da Tabela 3.4 utilizando essa abordagem. Para o cálculo do tamanho do buffer compartilhado, foi utilizado a sugestão de Goldratt: some todos os tempos de folga e reduza-os em 50\%. Reinertsen [Rei97], Newbold [New98], Leach [Lea05] e Cohn [Coh06] sugerem um outro cálculo para o cálculo do buffer:

Buffer de projeto $=\sqrt{\sigma_{1}^{2}+\sigma_{2}^{2}+\ldots+\sigma_{n}^{2}} \quad$ no qual $\sigma_{i}$ representa o tempo de folga da atividade $i$

A abordagem da Corrente Crítica reduz os impactos causados pela Síndrome do Estudante e Lei de Parkinson, tornando mais provável que o plano termine no prazo estimado. Nos Métodos Ágeis de desenvolvimento de software, a Corrente Crítica está associada ao uso conjunto com outros Métodos Ágeis, como XP e Scrum [Coh06,lsd], e FDD [And04b].

\subsubsection{Tambor-pulmão-corda no desenvolvimento de software}

No desenvolvimento de software o uso do método tambor-pulmão-corda é uma adaptação direta do método tambor-pulmão-corda da manufatura. Baseado na premissa de que todo sistema sempre 


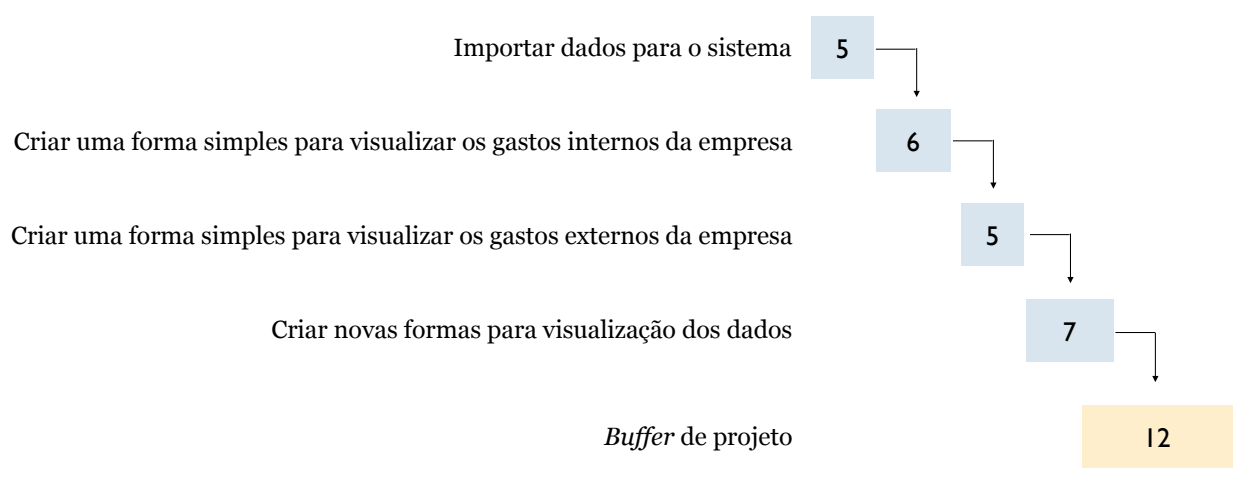

Tempo total: 35

Figura 3.14: Exemplo de um planejamento de release que utiliza buffer de projeto.

possui ao menos uma restrição [GC84] e ela que determina o desempenho do sistema, o tamborpulmão-corda é uma abordagem que busca melhorar sistematicamente o desempenho através de um processo de melhoria contínua composto por cinco passos [Gol90]:

1. Identificar a restrição do sistema;

2. Decidir como utilizá-la ao máximo;

3. Subordinar e sincronizar tudo à decisão acima;

4. Aumentar o fluxo da restrição;

5. Se em um passo anterior a restrição foi quebrada, volte ao passo 1. Mas não permita que a inércia cause uma restrição do sistema.

Para identificar a restrição é necessário enxergar o sistema como um todo, analisando como as partes interagem entre si. A seguir será apresentado um exemplo simplificado do uso dos conceitos do tambor-pulmão-corda no desenvolvimento de software. Um exemplo do uso do tambor-pulmãocorda em um caso real pode ser visto no artigo From Worst to Best in 9 Months [AD05] que apresenta um estudo de caso no qual os conceitos do tambor-pulmão-corda são utilizados para melhorar o desempenho de uma equipe de desenvolvimento da Microsoft.

A Figura 3.15 apresenta um processo simplificado de desenvolvimento de software. O número abaixo de cada etapa representa a quantidade de tarefas que a etapa consegue produzir. No exemplo apresentado, a fase de testes/integração é o gargalo do processo. A tendência em um gargalo é que as tarefas a fazer se acumulem na medida em que as etapas anteriores são finalizadas.

Normalmente, a restrição pode ser identificada observando a etapa com maior acúmulo de atividade. No exemplo apresentado, as atividades tem um acúmulo maior na fase de testes/integração. Uma vez identificada a restrição, deve-se verificar se ela está trabalhando eficientemente. No exemplo, uma verificação foi realizada para avaliar se existia algum problema que estava atrapalhando 


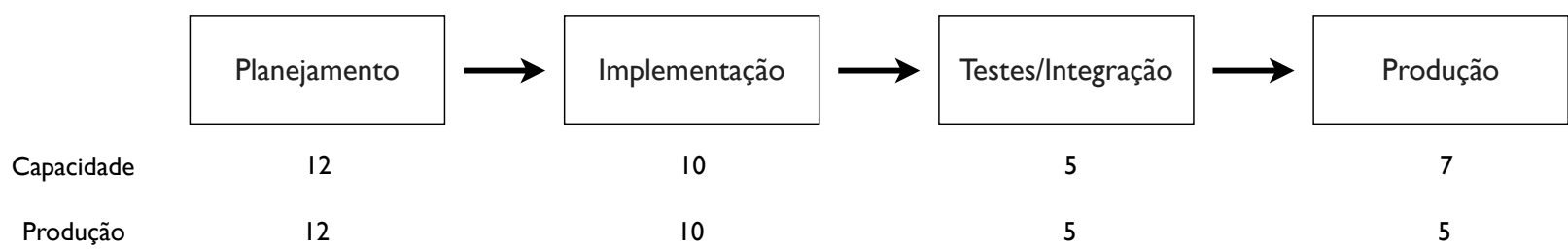

Figura 3.15: Processo simplificado de desenvolvimento de software que tenta manter todas as etapas trabalhando na capacidade máxima.

o trabalho durante a fase de testes/integração. Após a verificação, um nivelamento do fluxo de atividades foi realizado com base no fluxo da fase de testes/integração. A Figura 3.16, apresenta o processo após o nivelamento.

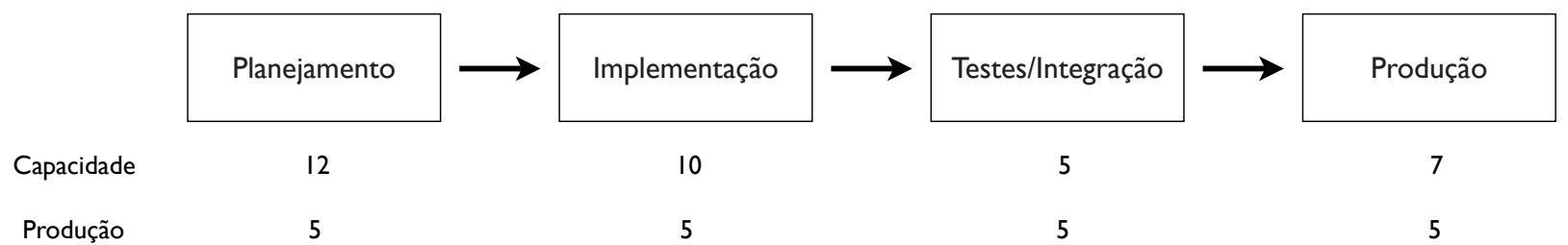

Figura 3.16: Processo simplificado de desenvolvimento de software que nivela o fluxo de atividades com base na restrição. O excesso de capacidade pode ser utilizado para melhorar o sistema.

Ao observar a Figura 3.16, é possível verificar que existem formas de melhorar o fluxo na restrição. Por exemplo, transferindo um analista para a fase de testes/integração, passando os testes para fase de implementação, fazendo o uso da prática de Integração Contínua, etc. . Para cada melhoria feita na restrição, deve-se nivelar o fluxo de desenvolvimento. Eventualmente, a fase de testes/integração, deixará de ser a restrição. Nesse caso, deve-se iniciar novamente o ciclo de melhoria contínua.

Embora simples, esse exemplo mostra que alguns problemas de desempenho não estão relacionados ao desempenho direto dos trabalhadores, e sim, ao uso correto deles. Um importante aspecto a ser observado, é que em atividades que não são a restrição é possível trabalhar "ineficientemente" sem afetar o fluxo de desenvolvimento. No exemplo apresentado, os desenvolvedores poderiam "gastar" o tempo auxiliando o desenvolvimento como um todo ou aprimorando suas habilidades. Por exemplo, estudando novas tecnologias, diminuindo a dívida técnica do sistema, auxiliando a equipe de integração ou conversando com o cliente para verificar que as funcionalidades feitas satisfazem sua exigência, evitando dessa forma que uma funcionalidade que não seria utilizada seja integrada no sistema.

\subsection{Conclusão}

Esse capítulo apresentou duas abordagens de desenvolvimento de software que foram baseadas nos métodos de manufatura estudados, descrevendo seus princípios e práticas. 


\subsubsection{Lean Software Development}

A abordagem de Lean Software Development é uma adaptação de princípios do sistema de produção da Toyota, no qual Mary e Tom Poppendieck traçam paralelos entre valores e princípios de Lean com o desenvolvimento de software, fornecendo sete princípios:

1. Elimine o desperdício: desperdício é qualquer atividade que não agrega valor ao cliente. Os três maiores desperdícios no desenvolvimento de software são: construir a funcionalidade errada, diminuir o aprendizado (e.g., gerenciar seguindo um plano rígido e separar a tomada de decisões do trabalho) e thrashing (Práticas que interferem com o fluxo de valor; e.g., multitarefa, dívida técnica).

2. Inclua a qualidade no processo: é uma estratégia que minimiza a inspeção após a ocorrência de defeitos, através da prevenção de criação dos mesmos durante o desenvolvimento. Em todas etapas de desenvolvimento, testes devem ser utilizados para estabelecer uma sensação de confiança quanto a corretude do sistema. O código e o design devem ser simples, facilitando a adição de novas funcionalidades.

3. Crie conhecimento: ao contrário do cenário numa linha de produção em massa, o software não é algo previsível ou imune a mudanças [LB03]. O desenvolvimento é um processo de aprendizado, que envolve tentativas e erros. Desenvolver é como criar uma receita, enquanto produzir é seguir os passos de uma receita [PP03].

4. Adie comprometimentos: a tomada de decisão prematura é um modo falho de planejamento, pois restringe o aprendizado, agrava os impactos de defeitos, limita a utilidade do produto e aumenta o custo de mudanças. Práticas de desenvolvimento que possibilitam decisões tardias são efetivas em domínios que envolvem incertezas, pois permitem obter flexibilidade durante o processo de desenvolvimento do produto.

5. Entregue rápido: Empresas que competem com base na velocidade, frequentemente, possuem vantagens em relação aos seus concorrentes, pois, possuem um processo com menos desperdício, poucos problemas e um profundo conhecimento das necessidades do cliente.

6. Respeite as pessoas: Respeitar as pessoas significa respeitar o intelecto e sua capacidade, dando a elas planos e objetivos justos e confiando que as equipes podem se auto-organizar para atingir o objetivo.

7. Otimize o todo: Uma organização lean otimiza todo o fluxo de valor, desde o momento em que recebe um pedido para atender a necessidade do cliente até o momento em que o software é entregue. Otimizações pontuais nem sempre são sinérgicas quando precisam funcionar simultaneamente. Otimizações macro canalizam os esforços para aumentar a satisfação dos usuários finais através de um produto consistente.

A Tabela 3.5 apresenta um apanhado geral das práticas e seus princípios associados. 
Tabela 3.5: Apanhado geral das práticas e princípios de Lean Software Development.

\begin{tabular}{|l|l|}
\hline Princípio & Práticas associadas \\
\hline Elimine desperdícios & Mapa de Fluxo de Valor \\
\hline Inclua a qualidade no processo & $\begin{array}{l}\text { Testes automatizados, programação pareadas, desenvolvimento guiado } \\
\text { por testes, integração contínua e clareza do código. }\end{array}$ \\
\hline Crie conhecimento & Desenvolvimento iterativo e Set-Based Design. \\
\hline Adie comprometimentos & Refatoração e Set-Based Design. \\
\hline Entregue rápido & Folga, iteração e sistemas kanban. \\
\hline Respeite as pessoas & Quadro kanban, taskboard, andon e dashboard. \\
\hline Otimize o todo & Mapa de Fluxo de Valor e story mapping. \\
\hline
\end{tabular}

\subsubsection{Teoria das Restrições}

A Teoria das Restrições, criada por Goldratt, tem sido examinada por diversos praticantes de métodos ágeis [Coc06, BA04, PP06], entre as diversas abordagens existentes, duas merecem destaques no desenvolvimento de software:

- Gerenciamento de Projetos usando Corrente Crítica: Criada por Goldratt, o CCPM, é uma aplicação dos princípios da Teoria das Restrições no gerenciamento de projeto. Segundo Goldratt, o CCPM é um método de gerenciamento que permite reduzir e controlar cronogramas de projeto através do uso da Corrente Crítica. O CCPM identifica problemas decorrentes da incerteza em projetos e protege o que é crítico no projeto, como resultado, a parcela do tempo que foi acrescentada como segurança, ou incerteza, no cronograma tradicional é retirada e administrada, reduzindo o tempo de execução do projeto. Embora CCPM não seja um método ágil, alguns praticantes tem utilizado este método como um complemento aos métodos ágeis, em especial, Feature Driven Development [And04b].

- Tambor-pulmão-corda: No desenvolvimento de software o uso do método tambor-pulmãocorda é uma adaptação direta do método tambor-pulmão-corda da manufatura. Ela afirma que o desempenho de um sistema pode ser melhorado, ao seguir os seguintes passos:

1. Identifique a restrição do sistema;

2. Decida como explorar a restrição do sistema;

3. Subordine tudo à decisão acima;

4. Eleve a restrição do sistema;

5. Se em algum passo anterior, a restrição deixou de ser a restrição atual, volte ao primeiro passo. 


\section{Capítulo 4}

\section{Estudo comparativo}

Nesse capítulo um estudo comparativo dos métodos de desenvolvimento de software baseados na indústrias de manufatura é apresentado. Esse estudo visa estender o trabalho feito por Abrahmssom et al. [AOS10], que analisa e compara diversas abordagens ágeis existentes de acordo com um arcabouço proposto por eles, acrescentando os métodos de desenvolvimento de software baseados na indústria de manufatura que afirmam ser ágeis [PP03, And04b].

Para o estudo, foi utilizado como base o mesmo arcabouço proposto por Abrahamssom et al. que avalia o desempenho dos métodos estudados através de seis perspectivas diferentes: suporte a gerenciamento de projeto, ciclo de vida do desenvolvimento de software, disponibilidade de orientações concretas para utilização, adaptabilidade na utilização, propósitos da metodologia e evidências empíricas.

\subsection{Arcabouço de Abrahamsson}

Nesta seção será apresentado um breve resumo da necessidade de cada perspectiva do arcabouço de Abrahmssom et al. A Tabela 4.1 apresenta uma breve descrição de cada perspectiva.

Tabela 4.1: Perspectivas de Abrahamsson et al. utilizadas para a análise. Maiores informações podem ser obtidas através do texto original [AOS10].

\begin{tabular}{ll}
\hline Perspectiva & Descrição \\
$\begin{array}{l}\text { Suporte a gerenciamento de projeto } \\
\text { Ciclo de vida do desenvolvimento de }\end{array}$ & O método dá suporte a atividades de gerenciamento de projeto? \\
software & Quais estág do ciclo de desenvolvimento o método cobre? \\
$\begin{array}{l}\text { Disponibilidade de orientações concre- } \\
\text { tas para utilização }\end{array}$ & O método depende de princípios abstratos ou provê orientações concre- \\
Adaptabilidade na utilização & tas: princípios abstratos vs. orientações concretas? \\
& O método se encaixa em todas as situações: universalmente pré-definido \\
Propósitos da metodologia & ou apropriados em algumas situações? \\
& Quais foram os objetivos dos criadores da metodologia: emancipatório, \\
Evidências empíricas & interpretativo, orientado a resultado? \\
\hline
\end{tabular}

Métodos devem ser eficientes (em relação ao consumo de tempo e de recurso) [KW92]. A eficiência exige a existência de atividades de gerenciamento de projetos para permitir que as tarefas de desenvolvimento possam ser apropriadamente organizada e executadas.

O ciclo de vida do desenvolvimento de software é a sequência de processos que uma organização utiliza para conceber, projetar e comercializar um software [BP88,CG98]. A perspectiva do ciclo 
de vida do desenvolvimento de software é necessária para verificar quais etapas são cobertas pelos métodos de desenvolvimento estudados.

Os métodos de desenvolvimento de software são frequentemente utilizados para outros propósitos além do planejado pelo autor [NA99]. Boehm [BP88] conclui que a falta de orientações concretas foi a causa de muitas falhas de projetos de software devido ao fato dos praticantes terem utilizados os métodos de desenvolvimento de forma errônea. Portanto, para avaliar quão bem os métodos podem ser utilizados para os propósitos planejados, uma perspectiva de disponibilidade de orientação concreta para utilização é necessária.

A perspectiva de adaptabilidade durante o uso deriva dos trabalhos de Kumar e Welke, Malouin e Landry, e Truex et al. [KW92, ML83, TBT01]. Essa perspectiva é utilizada para explorar quão bem os Métodos Ágeis reconhecem que uma solução única não se encaixa em todas as situações de desenvolvimento e se orientações são fornecidas para adaptar o método ágil nas diferentes situações.

A análise dos Métodos Ágeis à luz dos propósitos da metodologia é utilizada para realçar quais foram os objetivos dos criadores do método. Enquanto a evidência empírica é necessária para descobrir em quais tipos de evidências empíricas os Métodos Ágeis são baseados.

\subsection{Comparativo dos Métodos Ágeis baseados na indústria de manufatura}

Nesta seção, será comparado os métodos de desenvolvimento baseados na indústria de manufatura, em especial Lean Software Development e A Teoria das Restrições ${ }^{1}$. A tarefa de comparar metodologias é uma tarefa difícil e geralmente é baseada no julgamento subjetivo dos autores [SO91]. Comparações quasi-formal almejam superar as limitações subjetivas das técnicas de comparações informais oferecendo diferentes estratégias para compor uma base de comparação, i.e. arcabouços analíticos [AOS10]. Assim como o texto original, utilizamos as seis perspectivas analíticas propostas por Abrahamssom et al. vistas como relevantes e complementares para o propósito do estudo.

A Figura 4.1 apresenta a avaliação dos métodos em relação às três primeiras perspectivas da Tabela 4.1. Cada método é representado por três barras, sendo que o comprimento delas indica quais fases de desenvolvimento são cobertas por ele; a coloração de cada barra indica se o método suporta (cor cinza) ou não (cor branca) a perspectiva analisada. A barra superior indica a existência de suporte a gerenciamento de projeto. A barra intermediária indica quão bem o processo é descrito em cada etapa de desenvolvimento. Por fim, a barra inferior indica se o método depende principalmente de princípios abstratos ou se orientações concretas são fornecidas para o uso.

\subsubsection{Suporte a gerenciamento de projeto}

Lean Software Development é uma filosofia de gestão que possui um conjunto de princípios e práticas que auxiliam a organização a melhorar seu desempenho através da melhor utilização de seus recursos. A Teoria das Restrições é uma teoria criada para auxiliar as organizações a atingirem seus objetivos continuamente[18 e 43]. Embora Lean Software Development e A Teoria das Restrições não sejam explícitos quanto ao planejamento e gerenciamento de projetos, seus princípios podem ser utilizados para orientar o gerenciamento de todas as fases de desenvolvimento.

\footnotetext{
${ }^{1}$ A Corrente Crítica será analisada separadamente da Teoria das Restrições geral
} 


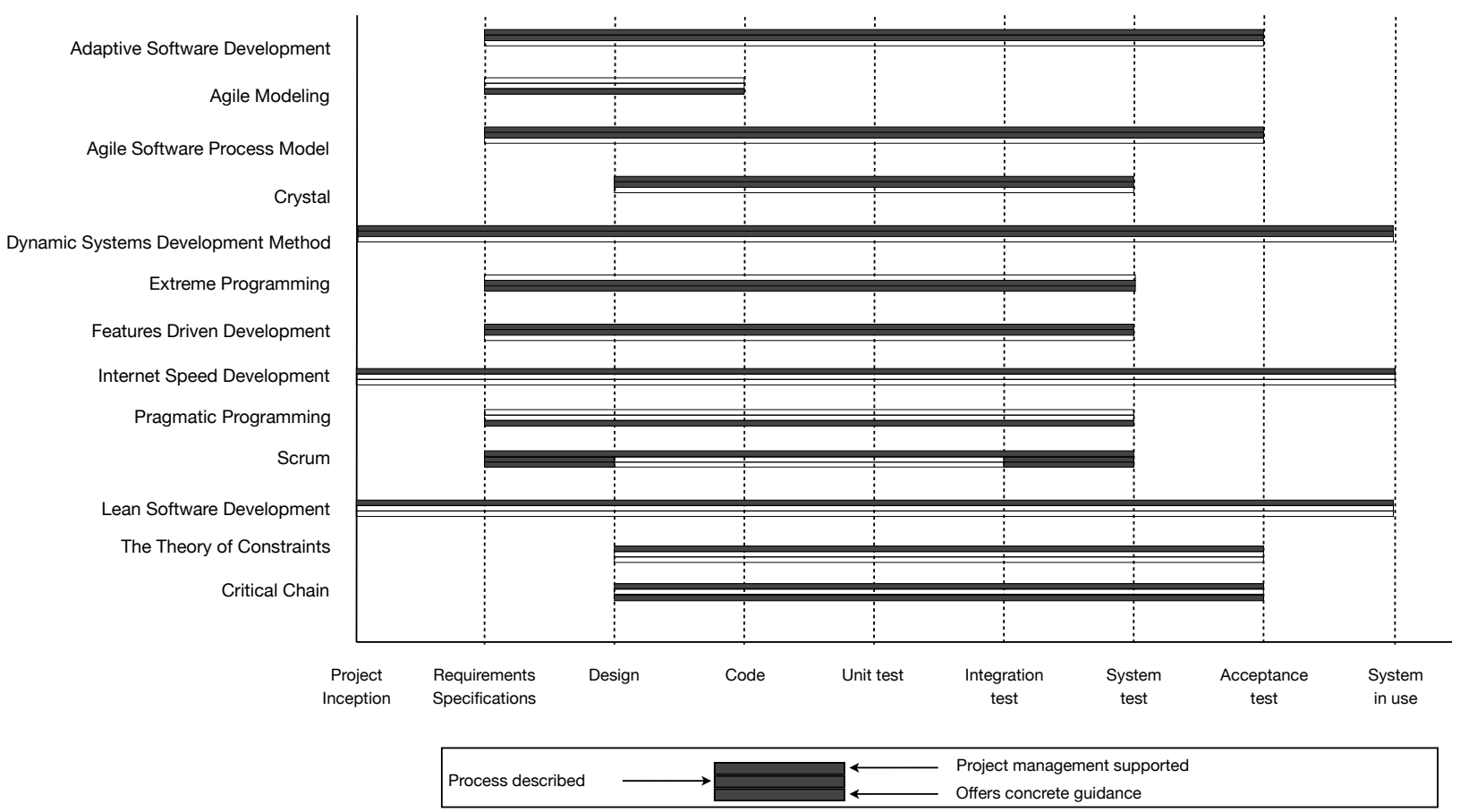

Figura 4.1: A Figura apresenta como os Métodos Ágeis estudados se comportam em relação a suporte de gerenciamento de projeto, ciclo de vida e disponibilidade de orientações concretas para utilização. A Figura é uma extensão do trabalho feito por Abrahamssom et al. [AOS10] no qual foram adicionado três métodos de desenvolvimento de software (Lean Software Development, Teoria das Restrições e Corrente Crítica).

A Corrente Crítica é uma aplicação direta dos princípios da Teoria das Restrições para gerenciamento de projetos ${ }^{2}$. A abordagem da CCPM analisa os recursos do projeto, montando uma cadeia crítica que mistura abordagens determinísticas e probabilísticas da análise de rede do cronograma [Ins04]. Esta análise é utilizada para o gerenciamento das atividades do projeto.

\subsubsection{Ciclo de vida do desenvolvimento de software}

Lean Software Development é uma abordagem que cobre todas as etapas de desenvolvimento de software, desde a concepção do projeto até o uso do sistema em produção, no entanto o processo é vagamente descrito [PP06].

A Corrente Crítica é uma abordagem voltada para a gestão das atividades de um projeto [Lea05], portanto, ela pode ser utilizada desde a fase de planejamento até a fase de testes de aceitação.

A Teoria das Restrições tem sido utilizada em diversos aspectos no desenvolvimento de software, cobrindo desde a fase de planejamento até a fase de testes de aceitação [And04a, And04b, AD05].

\subsubsection{Disponibilidade de orientações concretas para utilização}

Para avaliar a disponibilidade de orientações concretas durante o uso, utilizamos o mesmo critério de Abrahamsson et al. Quando o método impõe o uso de determinada prática, orientações concretas de como utilizá-la e adaptá-la devem ser fornecidas. Se essas orientações não forem

\footnotetext{
${ }^{2}$ Goldratt considera o desenvolvimento de software como um tipo específico de projeto
} 
fornecidas, na avaliação será interpretada como dependência do uso nos princípios abstratos.

Lean Software Development não exige o uso de nenhuma prática. Os sete princípios fornecidos podem ser utilizados pelas organizações para adaptar ferramentas, técnicas e práticas a seus contextos e capacidades específicas [PP06]. Poppendieck sugere o uso de algumas práticas em determinadas contextos [PP10], como Relatório A3, Set Based Design, Kanban, etc..., porém, nem sempre orientações concretas são fornecidas para utilizá-las.

A Teoria das Restrições enfatiza o uso de princípios abstratos sobre orientações concretas. As práticas devem ser desenvolvidas pela própria organização através do Processo de Raciocínio, no entanto, pouca orientação concreta de como criá-las é fornecida. Para tornar mais concreta a aplicação da Teoria das Restrições, Goldratt criou algumas aplicações específicas como o TamborPulmão-Corda para a manufatura e a CCPM para gerenciamento de projetos.

A Corrente Crítica é um conjunto bem definido de práticas e processos para o gerenciamento e planejamento de projetos [BC10]. Em uma série de webcast [Gol08a], Goldratt explica em detalhes quando e como uma determinada ação deve ser realizada durante a implantação da Corrente Crítica na organização.

\subsubsection{Adaptabilidade na utilização}

A maioria dos Métodos Ágeis de desenvolvimento de software permitem adaptações durante o uso, mas, poucos métodos fornecem orientações de como adaptá-los durante o uso [AOS10].

Em Lean Software Development, Poppendieck \& Poppendieck afirmam que as práticas devem levar em conta o contexto, portanto, para que possam ser utilizadas na organização elas devem ser adaptadas. Um conjunto de práticas é fornecido, permitindo que o usuário selecione a que melhor se adeque ao seu propósito. Lean Software Development fornece sete princípios que servem como referências para adaptações das práticas durante o uso, no entanto, orientações concretas de como adaptá-las são escassas.

A abordagem da Corrente Crítica permite que adaptações sejam feitas durante o uso. Goldratt fornece um plano detalhado de como adaptar o método na organização. Para cada prática é apresentada uma descrição, incluindo a premissa, objetivo e estratégia para implementação.

A Teoria das Restrições permite que adaptações sejam feitas durante o uso. No entanto, orientações concretas sobre como adaptar o método são escassas. Embora possua algumas ferramentas que auxiliem na adaptação durante o uso, um estudo conduzido por Sirias [Sir02] mostra que quando grupos heterogêneos foram impostos a um mesmo problema, resultados diferentes foram obtidos utilizando as mesmas ferramentas propostas pela Teoria das Restrições.

\subsubsection{Propósito da metodologia}

A maioria dos Métodos Ágeis tem como propósito o resultado final do produto, para isso, eles fornecem técnicas que auxiliam os profissionais da área a atingirem seus objetivos.

Assim como a maior parte dos Métodos Ágeis, Lean Software Development pode ser considerada como um método orientado a resultados. Isso pode ser observado através de uma afirmação feita por seus criadores [PP06]: "nosso objetivo é ajudar as organizações a começarem a trilhar um 
caminho mais eficaz para o desenvolvimento de software". Lean Software Development, também é interpretativo, pois, ao traçar os paralelos entre os princípios e práticas da Manufatura Lean com o desenvolvimento de software, os autores fornecem os conceitos e os motivos pelo qual uma determina prática ágil funciona. Por fim, Lean Software Development também pode ser considerado como crítico, pois, ao explicar os princípios da Manufatura Lean [PP06], Poppendieck \& Poppendieck explicam alguns dos problemas das abordagens tradicionais de desenvolvimento de software.

Assim com Lean Software Development, os métodos propostos por Goldratt podem considerados como orientados a resultados, interpretativos e críticos. O objetivo primário do criador da metodologia é melhorar o desempenho global do sistema, para isso, ele oferece um conjunto de passos que ajudam a entender as causas fundamentais dos problemas da organização. A Teoria das Restrições também pode ser considerada como crítica, pois tenta demonstrar os motivos pelo qual os conceitos da fabricação em massa não devem ser aplicados em ambientes de alta variabilidade, como desenvolvimento de software [Gol08b].

\subsubsection{Evidências empíricas}

O desenvolvimento das abordagens de desenvolvimento ágil de software não é baseado em pesquisas sistemáticas [DD08]. A maior parte dos métodos ágeis foram baseados nas experiências práticas dos seus autores em contrapartida de extensas pesquisas [AOS10]. Até o presente momento as únicas análises sistemáticas na área foram feita por Dyba e Dinsgor [DD08, AOS10] na qual os autores realizam uma análise sistemática dos Métodos Ágeis existentes e, Katayama e Goldman [KG11a] na qual os autores extendem o trabalho feito por Dyba acrescentando os métodos de desenvolvimentos baseados na indústria de manufatura. Ambos os autores concluem que dentro do estado da arte de evidências empíricas, as pesquisas acadêmicas ainda são escassas.

Para descrever o estado das pesquisas empíricas dos métodos de desenvolvimento baseados na indústria de manufatura foi conduzido uma pesquisa literaria na ISI Web of Science em 22 de Novembro. Foram encontradas 70 publicações relacionadas a Lean Software Development e a Teoria das Restrições, publicadas entre 1997 e 2010.

Durante o processo de revisão da pesquisa literária, foi observado que a maior parte das citações encontradas não eram relacionadas ao foco da pesquisa. Isto nos motivou a identificar quais eram as citações relevantes, e, posteriormente classifica-las de acordo com o propósito delas. Uma publicação foi descartada quando ela não atendia aos seguintes critérios:

- O link para o trabalho não estava funcionando;

- O trabalho correspondia ao título de um painel, workshop ou tutorial;

- O trabalho não era relacionado a área de desenvolvimento de software.

Posteriormente, todas publicações não descartadas foram distribuídas nas seguintes categorias:

- Estudo de caso: é uma técnica de estudo, no qual se faz uma pesquisa sobre um caso particular, para tirar conclusões sobre princípios gerais daquele caso específico; 
- Evidências empíricas: uma observação ou experimento direto que descreve ou explica um determinado fenômeno;

- Ferramentas e práticas: um estudo que investiga o uso de ferramentas ou práticas;

- Estudo conceitual: um estudo subjetivo, dependente do observador, que inclui a produção de ideias, considerando os prós e contras de possíveis implementações.

A Figura 4.2 apresenta o processo de revisão utilizado e a quantidade de publicações identificadas em cada passo. No passo 1, selecionamos todas as citações encontradas através do buscador ISI Web of Science que correspondiam aos seguintes termos "lean AND software AND development" e "theory AND of AND constraints AND software AND development" e com as seguintes opções para a busca: área da ciência da computação: software engineering, theory and methods and information systems. Tipos de documentos: proceeding paper, review or article. Bancos de dados: SCI-EXPANDED, SSCI, A\&HCI, CPCI-S, CPCI-SSH. Essa estratégia resultou em 70 publicações únicas relacionadas a Lean Software Development e a Teoria das Restrições, publicadas entre 1997 e 2010 .

No passo 2, com base no título da publicação, nós identificamos e descartamos 30 artigos que não eram claramente relacionadas ao foco da pesquisa. Por exemplo, a publicação Exploitation of Intelligent Slave Based on PROFIBUS-DP foi descartada com base no título. Finalmente no passo 3, excluímos as publicações onde não era claro pelo título, resumo ou palavra-chave se ele era relacionado ao foco da pesquisa, ou, se o trabalho correspondia a títulos de painéis, workshop ou tutorial. Após todo esse processo, obtivemos 32 publicações relevantes.

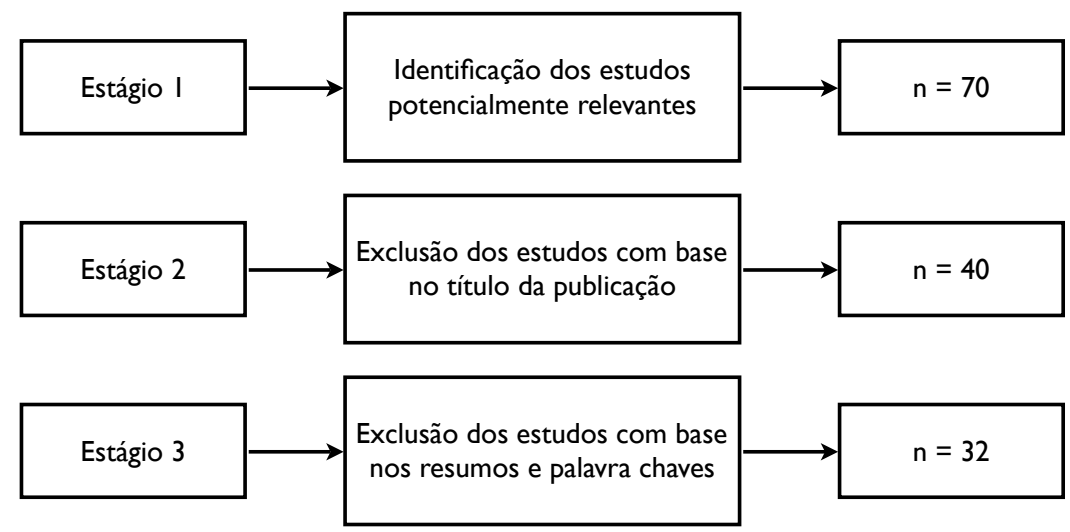

Figura 4.2: Passos utilizados para a seleção de publicações sobre Lean Software Development e Teorias da Restrições.

A Tabela 4.2 apresenta as publicações separadas nas categorias propostas. Como até o presente momento, nem todas as publicações de $2010^{3}$ foram indexadas na ISI Web of Science, optamos por retirar as publicações referentes ao ano de 2010 da Figura 4.3, que apresenta as publicações dos

\footnotetext{
${ }^{3}$ Até o presente momento, não foram indexadas as publicações da conferência Agile 2010 e XP 2010. Em 2009, essas duas conferências representaram X\% das publicações observadas
} 
métodos estudados em cada ano. As publicações referentes ao ano de 2010, são apresentadas na Figura 4.4. A Figura 4.5 mostra as publicações para cada método de desenvolvimento. Através das Figuras, é possível observar que existe um crescimento constante das publicações dos métodos de desenvolvimento baseados em manufatura.

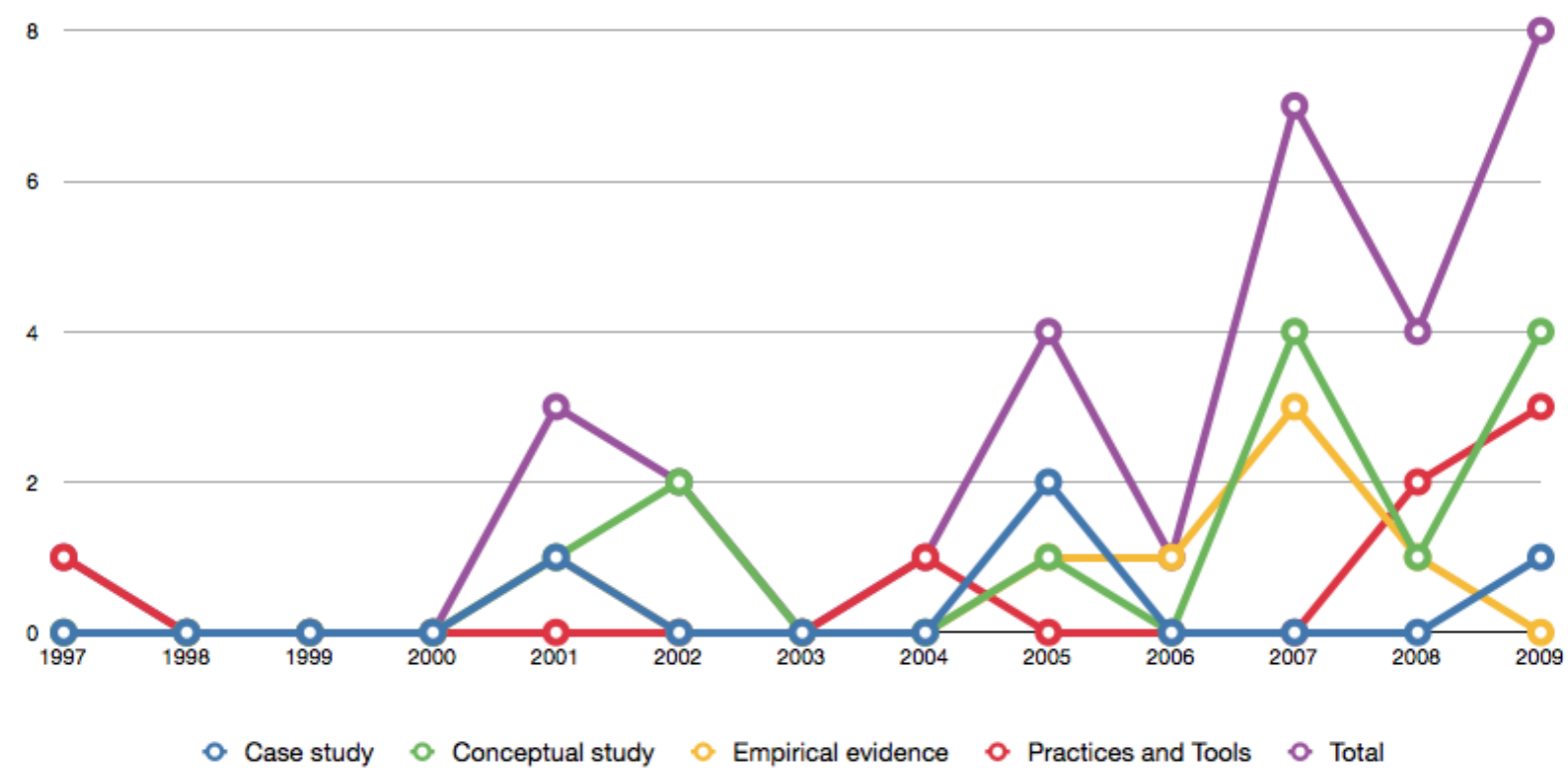

Figura 4.3: Publicações sobre Teorias da Restrições e Lean Software Development.

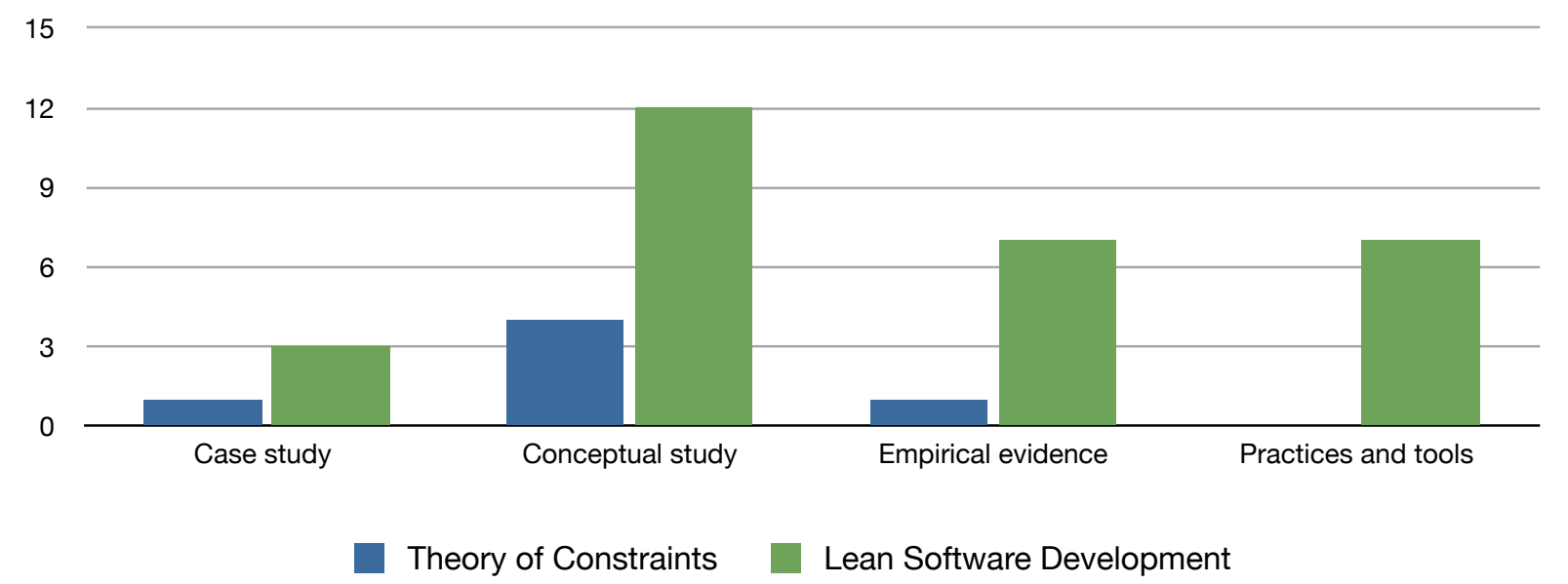

Figura 4.4: Publicações sobre Teoria das Restrições e Lean Software Development em 2010.

A maior parte dos estudos de caso de Lean Software Development e Teoria das Restrições podem ser identificadas em ambientes corporativos. Embora esses estudos e relatos forneçam ideias sobre as possibilidades e restrições dos métodos estudados, dados concretos são escassos. 
Tabela 4.2: Total de publicações separados por categorias.

\begin{tabular}{|l|l|l|l|l|}
\hline & $\begin{array}{l}\text { Case } \\
\text { study }\end{array}$ & $\begin{array}{l}\text { Conceptual } \\
\text { study }\end{array}$ & $\begin{array}{l}\text { Empirical } \\
\text { evidence }\end{array}$ & $\begin{array}{l}\text { Practices } \\
\text { and Tools }\end{array}$ \\
\hline Lean Software Development & 3 & 12 & 5 & 6 \\
\hline Theory of Constraints & 1 & 4 & 1 & 0 \\
\hline
\end{tabular}

\subsection{Conclusão}

Nos últimos anos, os Métodos Ágeis de desenvolvimento de software ganharam importância em diversos segmentos da indústria de software e da academia provocando uma quantidade substancial de debates e publicações. No entanto, dentro do estado da arte de evidências empíricas, as pesquisas acadêmicas sobre o assunto ainda se mantém escassas [AOS10]. A maior parte dos trabalhos publicados nessa área foram produzidos pelos praticantes dos métodos e ainda existem poucos estudos com rigor metodológico.

O objetivo desse estudo foi prover uma análise sistemática dos métodos de desenvolvimento baseados na manufatura. Para isso, os métodos estudados foram examinados através da perspectiva de Abrahamsson et al. O estudo mostra que os métodos de desenvolvimento baseados na manufatura cobrem diversas fases do ciclo de vida do desenvolvimento do software, porém orientações concretas de como adaptar ou utilizar ainda são escassas. Todos os métodos estudados possuem como propósito o resultado, fornecendo diversas práticas que auxiliam os praticantes a alcançarem seus objetivos. Embora existam diversas publicações, evidências empíricas ainda são escassas. 

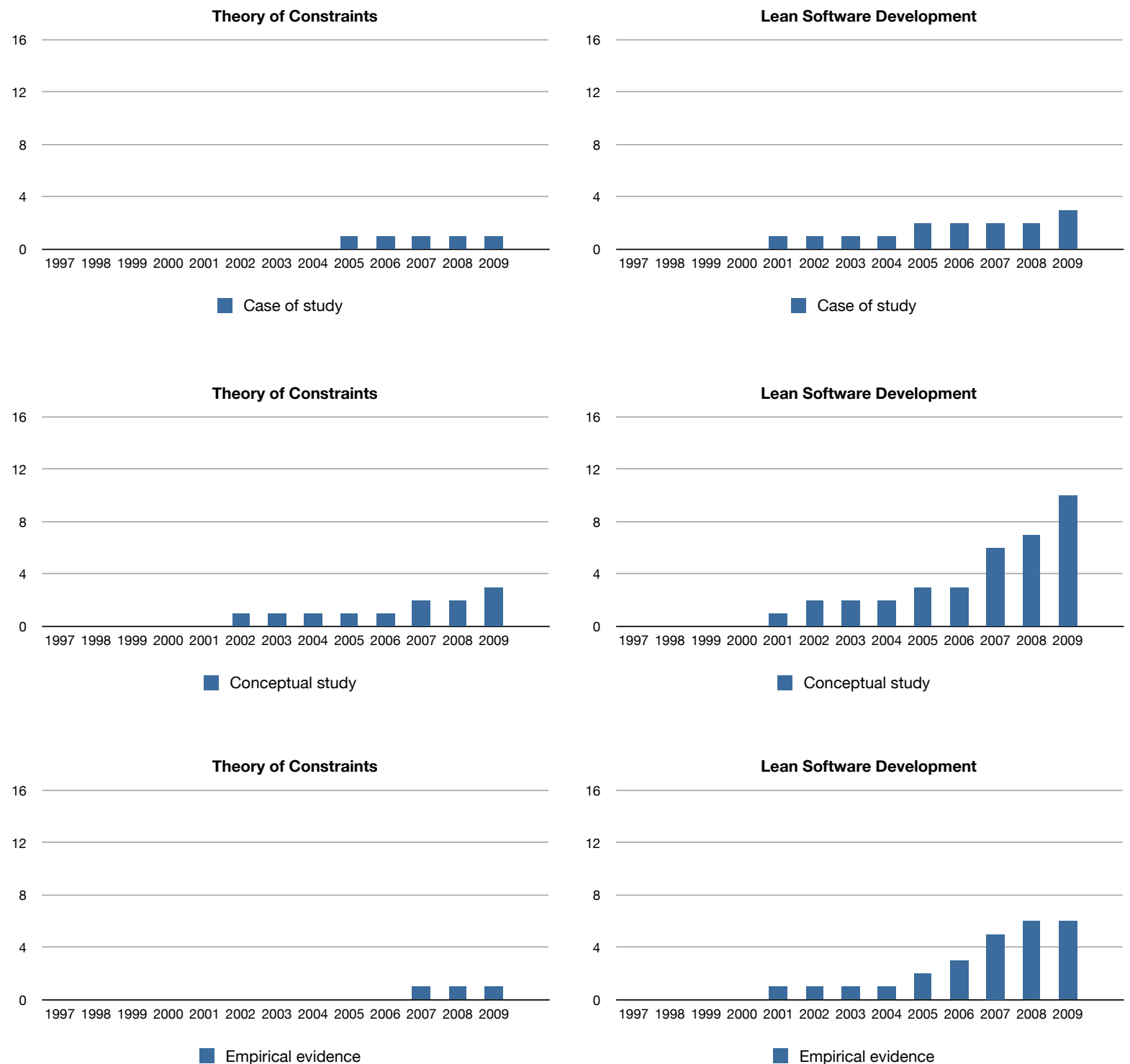

8

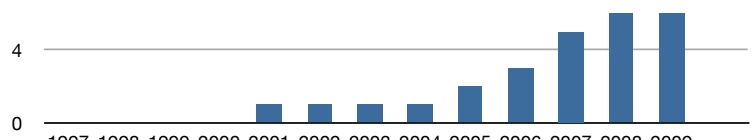

1997199819992000200120022003200420052006200720082009

Empirical evidence
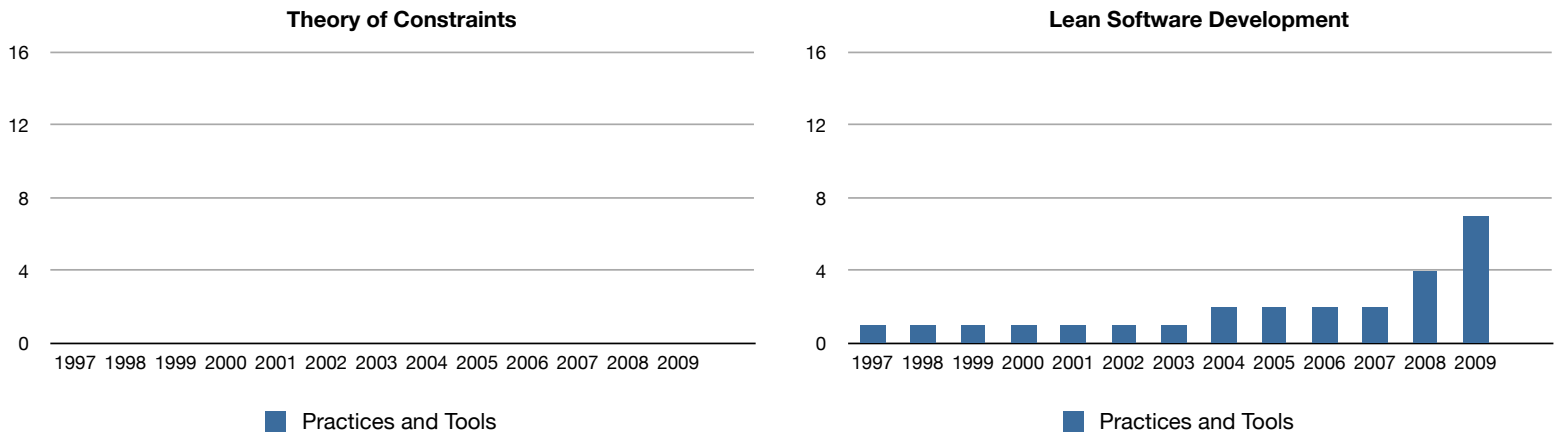

Figura 4.5: Gráfico cumulativo das publicações de Métodos Ágeis baseados na indústria de manufatura. 


\section{Capítulo 5}

\section{Lean Startup}

A abordagem de Lean Startup é uma aplicação dos conceitos de Lean Thinking ao processo de inovação e criação de produtos em condições de extrema incerteza. Um dos pontos centrais a essa metodologia é a preocupação em utilizar o termo hipótese ao invés de requisitos. O termo hipótese reforça que uma funcionalidade só se torna algo realmente útil quando validado e confirmado pelos clientes e usuários do produto [Rie11].

Nesse capítulo apresentamos uma breve introdução sobre como as ideias de Lean Startup podem ser utilizadas para melhorar a macro-eficiência do processo de desenvolvimento.

\subsection{Aproximando o desenvolvimento de software às necessidades do cliente}

No competitivo mercado de software o lançamento de novos produtos, sejam estes completamente novos ou evoluções de produtos já existentes, passou a ser muito importante para um bom desempenho de mercado [WW09]. Kotler (1996) identifica o desenvolvimento contínuo de produtos novos e aprimorados como a chave para a sobrevivência e crescimento das empresas. Segundo Doll \& Vonderembse (1991), o rápido desenvolvimento em tecnologias de produto e processo, avanços na tecnologia de informação e crescente competição global são características desse ambiente, no qual o sucesso depende da capacidade de se antecipar aos mercados e responder rapidamente e eficientemente com produtos que proporcionem alto valor aos consumidores.

Diante desse contexto, muitas empresas procuram diminuir o tempo e aumentar a produtividade dos seus processos de desenvolvimento de produto. Entretanto, mesmo com todos esses esforços, não é pequena a possibilidade de fracasso no lançamento de um novo produto. São cada vez mais comuns os casos de produtos que são retirados de linha pouco tempo após o seu lançamento no mercado [Bla06].

Segundo Reinertsen [Rei97], a maior parte dos lançamentos mal sucedidos são decorrentes de falhas na concepção dos produtos, a partir de uma visão equivocada do mercado ou mesmo por ignorar o que este deseja. Entretanto, embora a falha de concepção seja a principal causa para o fracasso, a maioria das empresas se concentram em reduzir os riscos técnicos durante o processo de desenvolvimento do produto. Porém, como Drucker [DW01] observa: "Nada é mais inútil do que fazer com eficiência extraordinária algo que não precisaria ser feito de jeito algum".

A Manufatura Lean descobriu que para ser eficaz, os princípios de Lean Thinking devem ser aplicados por toda a cadeia de produção, como consequência, atualmente observamos um grande 
investimento nas áreas de cadeia de suprimentos e logísticas em adição a Manufatura Lean. Analogamente, os princípios de Lean Thinking devem ser expandidos além da área de desenvolvimento de código, alcançando todo o processo de desenvolvimento, como concepção do produto, identificação de requisitos e validação de que o software desenvolvido realmente atende a necessidade do cliente, evitando dessa forma que o projeto seja apenas um "sucesso técnico" [Pop03c].

Para evitar que o projeto seja apenas um "sucesso técnico", os envolvidos no desenvolvimento de software devem se preocupar com os aspectos econômicos, se preocupando constantemente em agregar valor de negócio ao sistema que estão desenvolvendo. Nos Métodos Ágeis esse conceito é evidenciado através do primeiro princípio do Manifesto Ágil: "Nossa maior prioridade é satisfazer o cliente através da entrega rápida e contínua de software que traga valor". Esse princípio é um dos motivos pelo quais os clientes/stakeholders são responsáveis pela priorização das Histórias nas reuniões de planejamento.

Um processo de desenvolvimento ágil acontece em ciclos que têm por objetivo produzir e integrar partes do software. Cada iteração pode durar desde alguns meses até poucas horas, conforme a metodologia escolhida e as habilidades da equipe. Dessa forma, o processo torna-se flexível para acomodar mudanças funcionais e de prioridade durante a construção do sistema. No fim de cada ciclo, o software pode ser entregue ao cliente para que o restante do desenvolvimento seja direcionado pelo seu feedback. Dessa forma, os Métodos Ágeis dependem da existência de um Product Owner ou Cliente que deve entender do negócio e conhecer os verdadeiros usuários do sistema para que possa proporcionar segurança na definição e priorização das Histórias. Nesse tipo de ambiente, onde o problema é conhecido, a adoção de Métodos Ágeis tem mostrado excelentes resultados que são amplamente descritos na literatura [BK07,LWC04, MM05, LC04].

No entanto, a realidade do mercado é que nem sempre durante a construção de um produto, o problema é conhecido. Em startups, organizações dedicadas a criar um produto novo sobre condições de extrema incerteza, não é possível conhecer os verdadeiros usuários do sistema [Bla06]. Nesses tipos de ambientes, é comum que as premissas do plano de negócio sejam utilizadas como referências para decisões do dia-a-dia, e o progresso seja medido pelo avanço nas etapas deste plano. Mesmo em empresas que utilizam metodologias ágeis de desenvolvimento, apesar dos releases de software serem menores e mais constantes, o loop de feedback geralmente fica restrito à equipe dentro da própria empresa até a abertura do produto para os testes alpha e beta.

O problema é que, quando o produto é colocado à prova real do mercado, parte das premissas do plano de negócios inicial não se mostram verdadeiras, e as projeções (principalmente de vendas/receitas) acabam não se concretizando plenamente. As causas podem ser inúmeras: falta de demanda real no segmento escolhido, posicionamento mal-definido, má priorização de funcionalidades, preço não adequado, estratégia de marketing ineficiente, etc... Nesses ambientes, a maior razão para o fracasso durante a criação de um produto não é o processo de desenvolvimento, e sim, o desenvolvimento de um produto que clientes não necessitam [Bla06].

Em uma visão macro, essa forma de desenvolvimento pode ser comparada com a abordagem Push: construa a funcionalidade e verifique se as pessoas gostariam de utilizá-la. O problema 
dessa abordagem é que ela não evita o pior tipo de desperdício: a produção de funcionalidades desnecessárias. Gilb observa que a maior parte das práticas ágeis são centradas no desenvolvimento, e poucas são centradas nas atividades para entender a necessidade do cliente. O resultado é que em ambientes em que o aprendizado sobre o cliente deveria ser a medida primária de progresso, o "software funcionando é a medida primária de progresso" $\left[\mathrm{BBvB}^{+} 01\right]$, independentemente se o software agrega valor ou não ao cliente.

Beck [Bec10] observa que em uma startup, os Métodos Ágeis por si só trazem micro-eficiências ao processo de desenvolvimento quando não alinhadas a um processo maior de aprendizado sobre o cliente, pois perdem macro-eficiências ao permitir que funcionalidades sejam construídas sem que os clientes necessitem. Ries sugere o uso do modelo Customer Development (ver Figura5.1) para complementar os Métodos Ágeis. Nessa abordagem, conhecida como Lean Startup (Customer Development + Métodos Ágeis), duas equipes são criadas. A primeira se concentra no modelo de Customer Development, criando hipóteses e experimentos para auxiliar no entendimento do cliente, enquanto a segunda equipe, responsável pelo desenvolvimento do produto, auxilia a primeira equipe a validar seus experimentos.

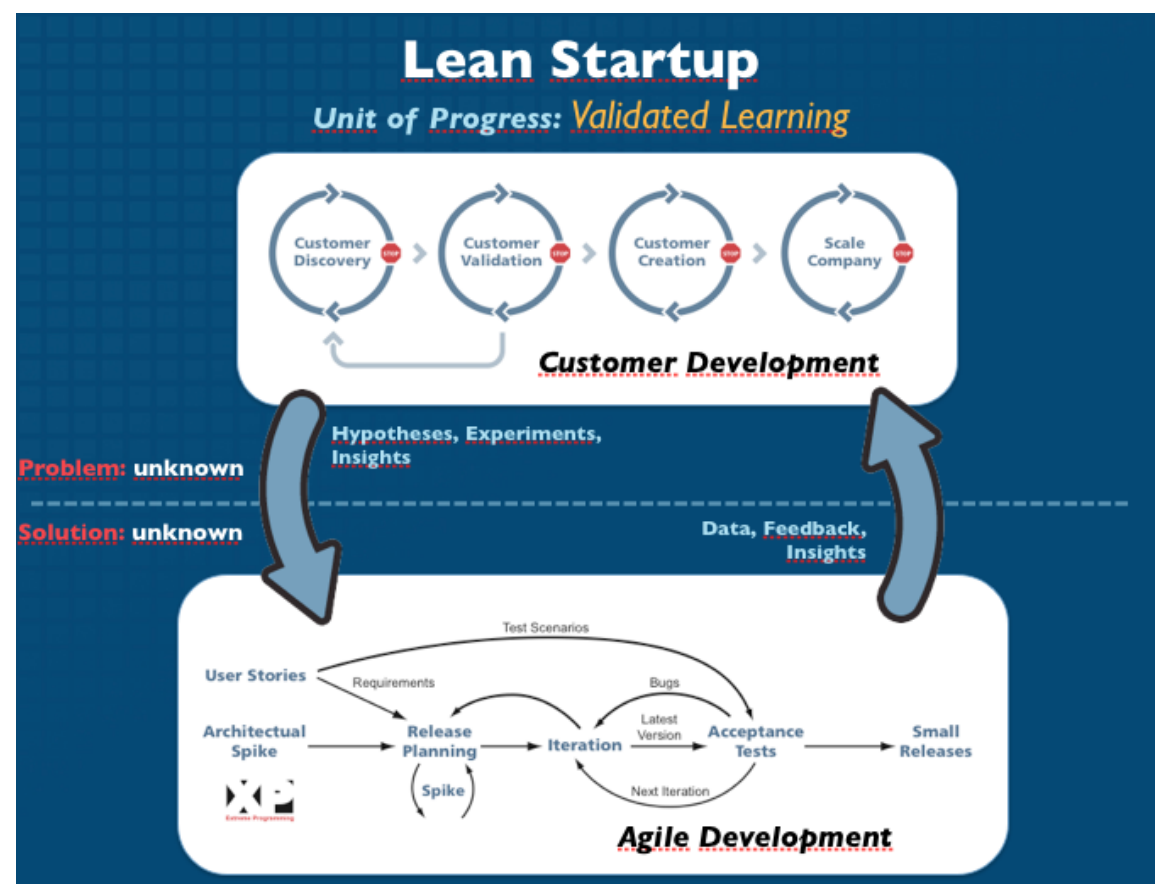

Figura 5.1: Lean Startup: combinando Customer Development com Métodos Ágeis.

Em Lean Startup a medida primária de progresso é o aprendizado obtido sobre cliente. Para isso, um ciclo de aprendizado fundamental é utilizado (ver Figura 5.2). O ciclo de aprendizado começa com um conjunto de ideias ou hipóteses que serão utilizadas para criar um artefato (protótipo, código, feature fake, página inicial, etc...) com o propósito de testar a hipótese. Posteriormente, dados são coletados e o resultado é utilizado para validar ou refutar a hipótese, direcionando os próximos passos. Dessa forma, o desenvolvimento seria similar a abordagem Pull, na qual o processo 
de desenvolvimento só começa quando uma necessidade concreta (de aprendizado ou demanda do cliente) é identificada. A Figura 5.3 apresenta um exemplo do uso desse ciclo.

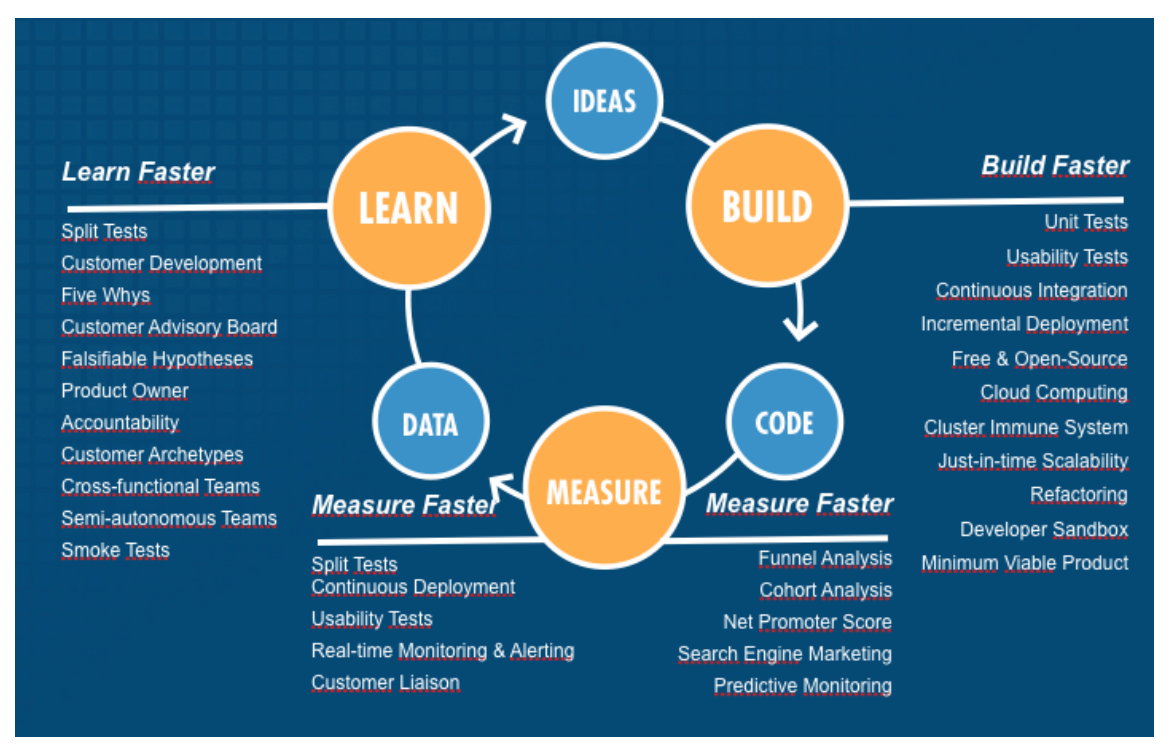

Figura 5.2: Ciclo de aprendizado.
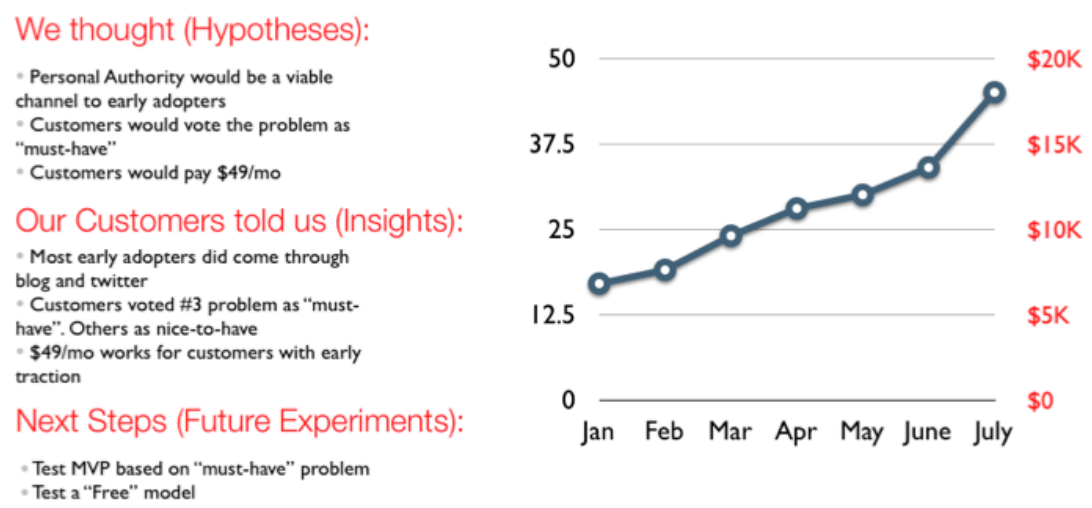

Figura 5.3: Hipótese, validação e futuros experimentos.

\subsection{Conclusão}

Nesse capítulo apresentamos uma breve introdução sobre como as ideias de Lean Startup podem ser utilizadas para melhorar a macro-eficiência do processo de desenvolvimento, mostrando como seus conceitos podem ser utilizados para reduzir uma das maiores fontes de desperdício em software: a produção de funcionalidades desnecessárias. Segundo esse método, o principal objetivo de uma empresa deve ser acelerar o processo de aprendizado sobre o cliente, formulando hipóteses a respeito do seu modelo de negócios e do uso do seu produto e em seguida validando-os através de protótipos capazes de colher informações sobre seu usuário final. 


\section{Capítulo 6}

\section{Considerações finais}

Esse trabalho estudou os princípios e práticas baseados na indústria de manufatura que foram incorporado pelos Métodos Ágeis de desenvolvimento de software. Além da discussão sobre os conceitos e teorias relacionados aos Métodos Ágeis, um estudo comparativo foi feito para avaliar as principais características dos métodos estudados.

Apresentamos um pouco da história e motivação por trás dos métodos de manufatura estudados, enfatizando as principais características que foram incorporadas pelos Métodos Ágeis de desenvolvimento de software e em seguida, apresentamos como foi feita a adaptação destas para o desenvolvimento de software. A escolha das melhores práticas em uma determinada situação depende do contexto de cada equipe. Assim como o processo é adaptativo, a escolha das práticas também deve ser passível de adaptações. Embora o objetivo de boa parte das técnicas apresentadas seja melhorar o processo, é importante notar que a produção desnecessária de funcionalidades é o pior tipo de desperdício possível [PP06].

Por fim, esse estudo avaliou e sintetizou as principais características dos métodos de desenvolvimento estudados através de um estudo comparativo. As duas abordagens foram classificadas nos termos e categorias propostos pelo arcabouço de Abrahamssom et al. [AOS10], um arcabouço que avalia o desempenho de um método de desenvolvimento em relação ao suporte a gerenciamento de projeto, ciclo de vida do desenvolvimento de software, disponibilidade de orientações concretas para utilização, adaptabilidade na utilização, propósitos da metodologia e evidências empíricas.

\subsection{Contribuições}

Dentre as principais contribuições deste trabalho, destacam-se:

- Criação de uma referência única e concisa sobre os métodos de desenvolvimento de software baseados na indústria de manufatura;

- Uma investigação dos principais métodos de manufatura que tiveram seus princípios e práticas incorporados pelos Métodos Ágeis de desenvolvimento de software;

- A classificação de duas abordagens de desenvolvimento utilizando o arcabouço de Abrahamssom et al., contribuindo para a construção de análises sistemáticas de métodos de desenvolvimento de software; 
- Publicação de três artigos: From Manufacture to Software Development: A Comparative Review [KG11a], Retrato da comunidade acadêmica de Métodos Ágeis no Brasil [KG11b], Genesis and Evolution of the Agile Movement in Brazil $\left[\mathrm{CGK}^{+} 11\right]$.

\subsection{Trabalhos futuros}

O estudo apresentado avaliou apenas duas abordagens de desenvolvimento de software que foram claramente baseadas em métodos da indústria de manufatura, em especial, a Manufatura Lean e a Teoria das Restrições. Seria interessante verificar a existência de outros métodos e técnicas da indústria de manufatura que ainda não foram aplicadas no desenvolvimento de software.

Outra adição interessante seria conduzir estudos para que novas práticas possam ser propostas e validadas. Dessa forma, as práticas que apresentamos nesse trabalho, juntamente com as de outros trabalhos da literatura, poderiam ser agrupadas para constituir um portifólio de práticas ágeis ao qual as equipes de desenvolvimento podem recorrer para selecionar as que mais se adequam ao contexto do seu projeto. Além disso, pesquisas em ambientes controlados e estudos empíricos seriam excelentes complementos a esse trabalho.

Por fim, considero que um estudo sobre um desenvolvimento mais centrado no cliente seria uma ótima adição ao texto. Um breve resumo sobre esse assunto foi apresentado no Capítulo 5. 


\section{Apêndice A}

\section{Métodos Ágeis}

\section{A.1 O Manifesto Ágil}

Em Fevereiro de 2001, um grupo formado por 17 desenvolvedores experientes e líderes da comunidade de software se reuniram em Utah para discutirem idéias e procurar alternativas aos processos burocráticos e prescritivos ${ }^{1}$ adotados pela indústria de software. Dessa reunião surgiu o Manifesto do Desenvolvimento Ágil de Software $\left[\mathrm{BBvB}^{+} 01\right]$, que destaca as diferenças com relação às abordagens prescritivas e define seus valores e princípios:

- Indivíduos e interações entre eles são mais importantes que processos e ferramentas;

- Software funcionando é mais importante que documentação completa e detalhada;

- Colaboração com o cliente é mais importante que negociação de contratos;

- Adaptação a mudanças é mais importante que seguir um plano.

Apesar da importância dos itens à direita, os Métodos Ágeis dão mais valor para os itens destacados à esquerda. Além dos quatro valores básicos, o Manifesto Ágil apresenta 12 princípios que auxiliam a difusão e compreensão de suas idéias:

- A maior prioridade é a satisfação do cliente por meio da entrega rápida e contínua de software que traga valor;

- Mudanças nos requisitos são aceitas, mesmo em estágios avançados de desenvolvimento. Processos ágeis aceitam mudanças que trarão vantagem competitiva para o cliente;

- Software que funciona é entregue frequentemente, em períodos que variam de semanas a meses, quanto menor o tempo entre uma entrega e outra melhor;

- As pessoas relacionadas ao negócio e os desenvolvedores devem trabalhar em conjunto diariamente;

- Construa projetos formados por indivíduos motivados, fornecendo o ambiente e o suporte necessário e confiando que realizarão o trabalho;

\footnotetext{
${ }^{1}$ Processo de desenvolvimento basedo em um conjunto de atividades pré-definidas [Amb04]
} 
- O modo mais eficiente e eficaz de transmitir informações dentro e fora do time de desenvolvimento é a Comunicação face a face;

- A principal medida de progresso é software funcionando;

- Processos ágeis promovem o desenvolvimento em um ritmo sustentável. Os investidores, desenvolvedores e usuários devem ser capazes de manter um ritmo constante;

- Cuidar continuamente da excelência técnica e do bom design ajuda a aprimorar a agilidade;

- Simplicidade - a arte de maximizar a quantidade de trabalho não necessário - é essencial;

- Os melhores requisitos, arquiteturas e design surgem de equipes auto-gerenciadas;

- Em intervalos regulares, o time reflete sobre como se tornar mais eficiente, refinando e ajustando seu comportamento apropriadamente.

Essas características trazem dinamismo para o desenvolvimento, motivação para o time e informações mais precisas sobre a verdadeira situação do projeto para o cliente. De acordo com Fowler [Fow00], os Métodos Ágeis podem ser considerados como um meio termo entre a ausência de processo e um processo exagerado. Como exemplo, pode-se citar a criação de planos. Planos continuam sendo fundamentais ao desenvolvimento, entretanto, eles devem ser considerados apenas rascunhos que podem se adaptar a mudanças conforme a equipe aprende e passa a conhecer melhor o sistema.

O Manifesto Ágil apresenta uma nova filosofia para o desenvolvimento de software. Sob seus valores e princípios aparecem diversas abordagens mais específicas, com diferentes idéias, comunidades e líderes. Cada comunidade forma um grupo distinto, porém todas seguindo os mesmos princípios. A seguir serão apresentados os principais métodos ágeis de desenvolvimento de software.

\section{A.2 Programação Extrema}

A Programação Extrema (XP) foi um dos Métodos Ágeis que mais se destacou na última década. Beck [BA04] descreve esse métodos como um estilo de desenvolvimento que se concentra na excelência no desenvolvimento de software, visando: baixo custo, poucos defeitos, alta produtividade e alto retorno de investimento.

Segundo Beck [BA04], a Programação Extrema inclui:

- Uma filosofia de desenvolvimento de software baseada em cinco valores fundamentais: comunicação, feedback, simplicidade, coragem e respeito;

- Um conjunto de práticas que representam ações a serem tomadas no dia-a-dia com o objetivo de expressar os valores. Essas práticas se complementam entre si, amplificando ainda mais os seus efeitos;

- Um conjunto complementar de princípios que ajudam a ter uma visão mais concreta dos valores, além de fornecer diretrizes para tomadas de decisão; 
- Uma comunidade que compartilha desses valores e de muitas outras práticas similares.

Essa separação entre valores, princípios e práticas já estava presente na primeira edição de XP, porém sua importância foi reforçada na segunda edição. A Figura A.1 apresenta uma visão geral sobre a interação entre os valores, princípios e práticas de XP.

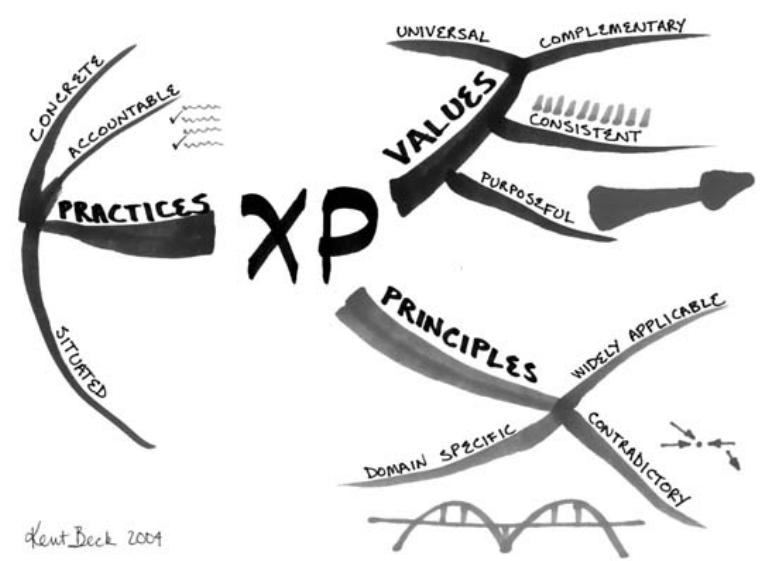

Figura A.1: Uma visão geral sobre a interação entre os valores, princípios e práticas de XP. Fonte: http://www.threeriversinstitute.org/XPInPictures.html. Retirado em Setembro de 2009.

\section{A.3 Scrum}

Desenvolvida nas décadas de 80 e 90 por Ken Schwaber, Jeff Sutherland, e Mike Beedle [SC04]. O Scrum se concentra nos aspectos gerenciais do processo de desenvolvimento de software, sem determinar como a equipe executará as tarefas de programação. Essa abordagem favorece a autoorganização da equipe e permite a integração com outras metodologias ágeis que foquem nas práticas de programação, como por exemplo, XP [Kni07, PP05, Dan05, JZ03].

O Scrum caracteriza-se como um processo empírico e adaptativo propondo iterações de duas semanas ou 30 dias (chamados Sprints) com acompanhamento diário por meio de Reuniões em Pé (ou stand-up meetings). A Figura A.2 apresenta o ciclo de vida do processo Scrum. No início de cada Sprint é feito uma reunião de planejamento que serve para estimar, definir a meta do Sprint e as tarefas necessárias (Backlog) para atingi-la.

Depois da reunião de planejamento, a equipe começa a fase de desenvolvimento do produto, que pode levar de uma a quatro semanas. Durante o Sprint, o Scrum Master ${ }^{2}$ assegura que os itens do backlog selecionado não mudarão. Dessa forma, ele protege a equipe de possíveis impedimentos permitindo que ela mantenha-se concentrada em seu objetivo. O dono do produto ${ }^{3}$ acompanha o

\footnotetext{
${ }^{2}$ O Scrum Master deve ensinar e acompanhar a utilização do Scrum e também proteger a equipe contra instabilidades e fatores externos que prejudiquem seu rendimento. Para exercer tal função, o Scrum Master deve possuir um amplo conhecimento sobre o processo e o produto, sendo responsável por auxiliar o dono do produto a tomar decisões que conduzam o projeto a obter o máximo retorno.

${ }^{3} \mathrm{O}$ dono do produto deve garantir que o produto entregue atenda aos anseios do patrocinador do projeto, priorizar quais funcionalidades devem ser entregues e quais agregam mais valor ao projeto. Para exercer tal função, o dono do produto deve possuir a visão do mesmo, sendo responsável pelo retorno sobre o investimento do projeto.
} 


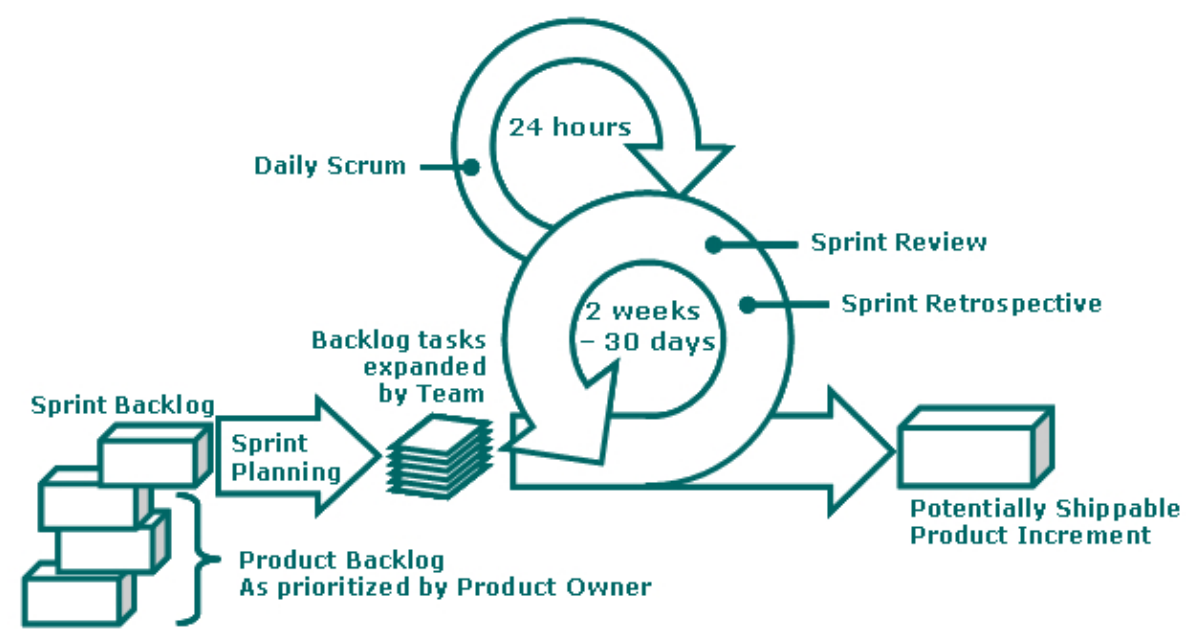

Figura A.2: Exemplo de um processo Scrum.Fonte: http://www.agilecoaching.dk

desenvolvimento e esclarece eventuais dúvidas sem poder mudar o escopo. No entanto, caso mudanças no ambiente de negócios forcem mudanças nos requisitos, o dono do produto pode cancelar o Sprint e realizar uma nova reunião de planejamento. Com isso, o Scrum mantém a visão geral da produtividade, que seria prejudicada caso requisitos pudessem ser modificados e adicionados durante um Sprint. Além disso, também provê um mecanismo de adaptação e correção para os requisitos.

Diariamente durante o Sprint, os membros da equipe se reúnem no mesmo horário para fazer a Reunião em Pé, uma rápida reunião para sincronizar o trabalho. Cada membro da equipe conta o que fez desde o último encontro, o que pretende fazer e quais problemas está tendo. Essas reuniões diárias auxiliam a equipe a descobrir antecipadamente problemas potenciais, além de disseminar melhor o conhecimento.

Quando o Sprint termina, a equipe apresenta o trabalho na reunião de revisão de Sprint ao dono do produto através de uma demonstração. O dono do produto faz testes para verificar se cada item atende as suas expectativas e determinar se a meta foi atingida. Após cada entrega, a equipe realiza uma reunião de retrospectiva para avaliar seu trabalho e identificar oportunidades para melhorar seu desempenho no próximo Sprint. O resultado de uma reunião de Retrospectiva costuma ser um pôster, destacando os principais pontos de melhoria que a equipe escolheu para se concentrar na próxima iteração.

\section{A.4 Família Crystal}

Cockburn propõe uma família de métodos por acreditar que diferentes abordagens são necessárias para equipes de tamanhos diferentes. Para lidar com projetos classificados como simples, ou até projetos críticos, Cockburn estabeleceu um conjunto de métodos, a Família Crystal, que compartilham propriedades comum como: entrega frequente, reflexão e comunicação, mas com diferentes graus de sofisticação e formalismo para serem usados conforme a complexidade de cada projeto [Coc04]. 
Os métodos Crystal são focados nos talentos e nas habilidades das pessoas, por isso permitem que o processo de desenvolvimento seja moldado conforme as características específicas da equipe, mesclando a sua cultura de trabalho com a proposta de desenvolvimento ágil. Cada método Crystal é caracterizado por uma cor de acordo com o tamanho e criticalidade do projeto [Coc06].

Entre os métodos Crystal mais conhecidos estão o Crystal Clear e a Crystal Orange. Crystal Clear é uma metodologia leve, para equipes de 1 a 8 pessoas, que usa ciclos de entrega de no máximo 3 meses. Esse método exige que a equipe trabalhe no mesmo ambiente e extremamente próxima para realizar a comunicação osmótica. Crystal Orange é uma metodologia mais pesada e apropriada para times de 20 a 50 participantes, esse método permite que a equipe se divida, pois lida com grupos maiores e a comunicação osmótica entre toda a equipe torna-se difícil. A estratégia nesse caso é dividir a equipe em subgrupos formados por membros com habilidades variadas e complementares. Cada subequipe é formada por analista de negócios, um designer de interface, de 1 a 3 programadores e opcionalmente uma analista de banco de dados e um testador. Assim, cada grupo poderá realizar comunicação osmótica internamente e deve manter contanto constante com os demais subgrupos, que estão trabalhando próximos, preferencialmente no mesmo andar, mas nunca em prédios diferentes. Crystal Orange baseia-se fortemente na comunicação e não oferece suporte para desenvolvimento com equipes distribuídas [Bas08]. 


\section{Referências Bibliográficas}

[AD05] D.J. Anderson and D. Dumitriu. From Worst to Best in 9 Months. TOCICO 2005 Conference, 2005. 2, 67, 73

[ADL96] R.D. Austin, T. DeMarco, and T. Lister. Measuring and managing performance in organizations. Dorset House Publishing, 1996. 38, 51, 63

[Amb04] S.W. Ambler. The object primer: agile modeling-driven development with UML 2.0. Cambridge Univ Pr, 2004. 87

[And04a] D. Anderson. Managing Lean Software Development with Cumulative Flow Diagrams . BorCon 2004, 2004. 41, 73

[And04b] D.J. Anderson. Agile management for software engineering: Applying the theory of constraints for business results. Prentice Hall, 2004. 2, 63, 66, 70, 71, 73

[AOS10] P. Abrahamsson, N. Oza, and M. Siponen. Agile Software Development Methods: A Comparative Review. In Agile Software Development: Current Research and Future Directions, pages 31-58. Springer; 1st Edition. edition, 2010. 2, 71, 72, 73, 74, 75, 78,85

[ASRW02] P. Abrahamsson, O. Salo, J. Ronkainen, and J. Warsta. Agile software development methods: Reviews and analysis. Relatório Técnico, Finlândia, 2002. 2

[AW00] Cockburn A. and L. Williams. The Costs and Benefits of Pair Programming. In eXtreme Programming and Flexible Processes in Software Engineering XP2000, pages 223-247. Addison-Wesley, 2000. 47

[BA04] K. Beck and C. Andres. Extreme programming explained: embrace change. AddisonWesley Professional, 2004. 42, 59, 63, 70, 88

[Bal00] G. Ballard. Positive vs negative iteration in design. In Proceedings of the International Group for Lean Construction 8th Annual Conference (IGLC-8), Brighton, UK. Citeseer, 2000. 48

[Bal05] M. Ballé. Lean attitude. IEE Manufacturing Engineer, 84(2):14-19, 2005. 60, 61

[Bas08] D. Bassi. Experiências com desenvolvimento ágil. Dissetação de Mestrado, Universidade de São Paulo, 2008. 91

$\left[\mathrm{BBvB}^{+} 01\right] \quad$ K. Beck, M. Beedle, A. van Bennekum, A. Cockburn, W. Cunningham, M. Fowler, J. Grenning, J. Highsmith, A. Hunt, R. Jeffries, J. Kern, B. Marick, R. Martin, S. Mellor, K. Schwaeber, and D. Sutherland, J. Thomas. Manifesto for agile software development. 2001. Disponível em http://www.agilemanifesto.org. Acessado em 15/03/2011. $1,83,87$ 
[BC10] C.S. Budd and J. Cerveny. A Critical Chain Project Management Primer (Chapter 3 of Theory of Constraints Handbook). McGraw-Hill Professional, 2010. 36, 74

[Bec99] K. Beck. Extreme Programming Explained: Embrace Change. Addison-Wesley Professional, 1st edition, 1999. 47

[Bec03] K. Beck. Test Driven Development: By Example. Addison-Wesley Professional, 2003. 47

[Bec06] K. Beck. Implementation patterns. Addison-Wesley Professional, 2006. 47

[Bec10] K. Beck. To Agility, and Beyond. In Published Keynote at Startup Lesson Learned Conference, 2010. 83

[BJR99] G. Booch, I. Jacobson, and J. Rumbaugh. The unified software development process. Addison-Wesley Longman Publishing Co., 1999. 1

[BK07] P.C. Bernardo and F. Kon. Desenvolvendo com agilidade: Experiências na reimplementação de um sistema de grande porte. In Proceedings of the 1st Workshop on Rapid Application Development (WDRA'2007) in the Brazillian Symposium on Software Quality (SBQS'2007), volume 4, 2007. 82

[Bla06] S.G. Blank. The Four steps to the epiphany: Successful strategies for products that win. Cafepress, 2006. 81, 82

[BM98] S.J. Balderstone and V.J. Mabin. A Review of Goldratt's Theory of Constraints (TOC)-lessons from the international literature. In Proceedings of the 33rd Annual Conference of the Operational Research Society of New Zealand, Auckland, pages 205-214. Citeseer, 1998. 23

[Boe76] B.W. Boehm. Software Engineering. IEEE Transactions on Computers, 25:12261241, 1976. 44

[BP88] B. W. Boehm and P. N. Papaccio. Understanding and Controlling Software Costs. IEEE Trans. Softw. Eng., 14(10):1462-1477, 1988. 44, 71, 72

[BP04] G. Brandberg and M. Poppendieck. Interview with Mary Poppendieck: An introduction to Lean Software Development, 2004. Disponível em http://www.citerus.se/ post/220180-interview-with-mary-poppendieck-an-introduction. Acessado em: 14/03/2011. 43

[Byl83] G. Bylinski. An efficiency guru with a brown box. Fortune, 108:120-132, 1983. 23

$\left[\mathrm{CCG}^{+} 07\right] \quad$ G. Canfora, A. Cimitile, F. Garcia, M. Piattini, and C.A. Visaggio. Evaluating performances of pair designing in industry. Journal of Systems and Software, 80(8):13171327, 2007. 47

[CG98] G. Cugola and C. Ghezzi. Software Processes: a Retrospective and a Path to the Future. Software Process Improvement and Practice 4: 101-123, 1998. 71

$\left[\mathrm{CGK}^{+} 11\right]$ H. Corbucci, A. Goldman, E. Katayama, F. Kon, C. Melo, and V. Santos. Genesis and evolution of the agile movement in brazil - a perspective from the academia and the industry. 25th Brazilian Symposium on Software Engineering, 2011. 86 
[CJO03] A.G. Cass, S.M.S. Jr, and L.J. Osterweil. Formalizing rework in software processes. Software Process Technology, pages 16-31, 2003. 44

[CKI88] B. Curtis, H. Krasner, and N. Iscoe. A field study of the software design process for large systems. Communications of the ACM, 31(11):1268-1287, 1988. 48

[CLDL99] P. Coad, E. Lefebvre, and J. De Luca. Java modeling in color with UML: Enterprise components and process. Prentice Hall, 1999. 1

[CMS04] I. Cohen, A. Mandelbaum, and A. Shtub. Multi-project scheduling and control: A process-based comparative study of the critical chain methodology and some alternatives. Project Management Journal, 35:39-49, 2004. 2, 24

[CMS06] C.M. Christensen, M. Marx, and H.H. Stevenson. The tools of cooperation and change. Harvard business review, 84(10), 2006. 61

[Coc04] A. Cockburn. Crystal clear: a human-powered methodology for small teams. AddisonWesley Professional, 2004. 49, 90

[Coc05] A. Cockburn. Two case studies motivating efficiency as a "spendable" quantity. In Proceedings of the International Conference on Agility, pages 1-6, 2005. 41

[Coc06] A. Cockburn. Agile Software Development: The Cooperative Game (Agile Software Development Series). Addison-Wesley Professional, 2006. 1, 50, 63, 70, 91

[Coh04] M. Cohn. User stories applied: For agile software development. Addison-Wesley Professional, 2004. 64

[Coh06] M. Cohn. Agile estimating and planning. Prentice Hall Professional Technical Reference, 2006. 35, 36, 64, 65, 66

[Coh10] M. Cohn. Agile Teamwork: 3 Ways to Minimize Handoffs. Better Software Magazine, 2010. 45

[Coo08] Cooper, A. The wisdom of experience. Keynote Speech at Agile 2008 Conference, 2008. 45

[CS98] J.F. Cox and M.S. Spencer. The constraints management handbook. CRC, 1998. 23

[Cun] W. Cunningham. System of Names. Disponível em http://c2.com/cgi/wiki? SystemOfNames. Acessado em: 14/03/2011. 47

[Cun92] W. Cunningham. The WyCash portfolio management system. In ACM SIGPLAN OOPS Messenger, volume 4, pages 29-30. ACM, 1992. 28

[CW93] K.B. Clark and S.C. Wheelwright. Managing new product and process development: text and cases. Free Press, 1993. 35

[Dan05] A. Danait. Agile offshore techniques-a case study. In Agile Conference, 2005. Proceedings, pages 214-217. IEEE, 2005. 89

[DD08] T. Dybå and T. Dingsøyrr. Empirical studies of agile software development: A systematic review. Information and Software Technology, 2008, 2008. 2, 75 
[DeM86] T. DeMarco. Controlling Software Projects: Management, Measurement, and Estimates. Prentice Hall PTR Upper Saddle River, NJ, USA, 1986. 44

[Dem00] W.E. Deming. Out of the Crisis. The MIT Press, 2000. 63

[DeM02] T. DeMarco. Slack: Getting past burnout, busywork, and the myth of total efficiency. Broadway, 2002. 49

[Det97] H.W. Dettmer. Goldratt's theory of constraints: a systems approach to continuous improvement. ASQ Quality Press, 1997. 23

[Dij72] E.W. Dijkstra. The humble programmer. Communications of the ACM, 15(10):859866, 1972. 46

[DL99] T. DeMarco and T. Lister. Peopleware: productive projects and teams. Dorset House Publishing Company, Incorporated, 1999. 44

[DLS06] E. Derby, D. Larsen, and K. Schwaber. Agile retrospectives: Making good teams great. Pragmatic Bookshelf, 2006. 53

[DW01] P.F. Drucker and G. Wilson. The essential drucker. Butterworth-Heinemann, 2001. 81

[Dye00] J.H. Dyer. Collaborative advantage: Winning through extended enterprise supplier networks. Oxford University Press, USA, 2000. 8

[ELS05] J. Erickson, K. Lyytinen, and K. Siau. Agile modeling, agile software development, and extreme programming: the state of research. Journal of Database Management (JDM), 16(4):88-100, 2005. 2

[ER98] J. Elton and J. Roe. Bringing discipline to project management. Harvard Business Review, 76(2):153-157, 1998. 24

[Eva03] E. Evans. Domain-driven Design: Tackling Complexity in the Heart of Software. Addison Wesley, 1st edition edition, 2003. 47

[Fag76] M.E. Fagan. Design and code inspections to reduce errors in program development. IBM Systems Journal, 15(3):182-211, 1976. 44

$\left[\mathrm{FBB}^{+} 02\right] \quad$ M. Fowler, K. Beck, J. Brant, W. Opdyke, and D. Roberts. Refactoring: Improving the Design of Existing Code. Addison Wesley, 2002. 48

[Fow] M. Fowler. xUnit. Disponível em http://www.martinfowler.com/bliki/Xunit. html. Acessado em: 14/03/2011. 46

[Fow00] M. Fowler. The new methodology. Software Development magazine, 2000. 41, 88

[Fow06] M. Fowler. Continuous Integration, 2006. Disponível em http://martinfowler. com/articles/continuousIntegration.html. Acessado em: 14/03/2011. 47

[Fre75] P. Freeman. Software systems principles: a survey. Science Research Associates, 1975. 46

[Fuj99] T. Fujimoto. The evolution of a manufacturing system at Toyota. Oxford University Press, USA, 1999. 6 
[GB93] D. Garvin and A. Building. Learning organization. Harvard Business Review, 74(4), 1993. 47

[GBG94] S.C. Gardiner, J.H. Blackstone, and L.R. Gardiner. The evolution of the theory of constraints. Industrial Management, 36:13-13, 1994. 24

[GC84] E.M. Goldratt and J. Cox. The goal: Excellence in manufacturing. North River Press, 1984. 24, 25, 41, 67

[GFG86] E.M. Goldratt, R.E. Fox, and G. Grasman. The race, volume 179. North River Press, 1986. 24

[GK09] E.M. Goldratt and Y. Kishira. CCPM e TOC: Uma revolução no Japão. Mundo Project Management, 28(5), 2009. 33

[Gol80] E. Goldratt. Optimized production timetable: a revolutionary program for industry. In APICS 23rd annual international conference proceedings, pages 172-176, 1980. 24

[Gol87] E.M. Goldratt. Computerized shop floor scheduling. International Journal of Production Research, 26(3):443-455, 1987. 24

[Gol90] E.M. Goldratt. What is this thing called theory of constraints and how should it be implemented? North River Press, 1990. 41, 61, 67

[Gol91] E.M. Goldratt. The haystack syndrome. North River Press, 1991. 25

[Gol94] E.M. Goldratt. It's not luck. North River Press, 1994. 24, 25

[Gol97] E.M. Goldratt. Critical chain. North River Press, 1997. 24, 34

[Gol02] E.M. Goldratt. Toc - self learning program, 2002. Disponível em http:// toc-goldratt.com/store. 24

[Gol03] E.M. Goldratt. Necessary and sufficient, 2003. Disponível em http:// toc-goldratt.com/store. 24

[Gol08a] E. Goldratt. Critical Chain Project Management (CCPM) Webcast, 2008. Disponível em https://www.tocvision.com. 74

[Gol08b] E.M. Goldratt. The Choice. North River Press, 2008. 25, 75

[Gro94] Standish Group. The CHAOS report, 1994. 1, 34, 43

[GSP00] E.M. Goldratt, E. Schragenheim, and C.A. Ptak. Necessary but not sufficient: a theory of constraints business novel. North River Press, 2000. 38

[HC01] J. Highsmith and A. Cockburn. Agile software development: The business of innovation. Computer, 34(9):120-127, 2001. 1

[Hin06] S. Hino. Inside the mind of Toyota: Management principles for enduring growth. Productivity Pr, 2006. 60

[id01] Toyota internal document. The Toyota Way 2001. 2001. 16 
[Ima86] M. Imai. Kaizen: The key to Japan's competitive success, volume 4. McGraw-Hill New York, 1986. 13

[Inc] Stratego Inc. Origins \& History Lean Manufacturing. Disponível em http://www . strategosinc.com/just_in_time.htm. Acessado em: 14/03/2011. 7

[Ins04] Project Management Institute. A Guide to the Project Management Body of Knowledge, Third Edition (PMBOK Guides). Project Management Institute; 3rd editions, 2004. 73

[JJ86] C. Jones and C. Jones. Programming productivity. McGraw-Hill New York, 1986. 44

[Joh02] J. Johnson. ROI, It's Your Job! In Published Keynote Third International Conference on Extreme Programming, 2002. 43, 48, 52

[Jon06] D. Jones. Heijunka: Leveling production. Manufacturing Engineering, 137(2):29-35, 2006. 12

[JZ03] B. Jensen and A. Zilmer. Cross-continent development using scrum and xp. Extreme Programming and Agile Processes in Software Engineering, pages 1014-1014, 2003. 89

[Ker01] N.L. Kerth. Project retrospectives: a handbook for team reviews. Dorset House Publishing Co., Inc., 2001. 53

[KG11a] E.T. Katayama and A. Goldman. From manufacture to software development: A comparative review. Agile Processes in Software Engineering and Extreme Programming, pages 88-101, 2011. 75, 86

[KG11b] E.T. Katayama and A. Goldman. Retrato da comunidade acadêmica de métodos Ágeis no brasil. Workshop Brasileiro de Métodos Ágeis (WBMA 2011), 2011. 86

$\left[\mathrm{KMWF}^{+} 01\right]$ M. Kajko-Mattsson, U. Westblom, S. Forssander, G. Andersson, M. Medin, S. Ebarasi, T. Fahlgren, S.E. Johansson, S. Törnquist, and M. Holmgren. Taxonomy of problem management activities. In Proceedings of the Fifth European Conference on Software Maintenance and Reengineering, pages 1-10. Published by the IEEE Computer Society, 2001. 48

[Kni07] H. Kniberg. Scrum and xp from the trenches. Info Q Enterprise Software Development Series, 2007. 89

[Kni10] H. Kniberg. Kanban and Scrum-making the most of both. Lulu. com, 2010. 57, 59

[KW92] K. Kumar and J. Welke. Methodology Engineering: a proposal for situation-specific methodology construction. John Wiley \& Sons, Inc., pages 257-269, 1992. 71, 72

[Lar04] C. Larman. Agile and iterative development: a manager's guide. Prentice Hall, 2004. 1,47

[LB03] C. Larman and V.R. Basili. Iterative and incremental developments. a brief history. Computer, 36(6):47-56, 2003. 48, 69 
[LC04] K.M. Lui and K.C.C. Chan. Test driven development and software process improvement in china. Extreme Programming and Agile Processes in Software Engineering, pages $219-222,2004.82$

[Lea99] L.P. Leach. Critical chain project management improves project performance. Project Management Journal, 30:39-51, 1999. 24

[Lea05] L.P. Leach. Critical chain project management. Artech House Boston, 2005. 66, 73

[LEC95] J.K. Liker, J.E. Ettlie, and J.C. Campbell. Engineered in Japan: Japanese technologymanagement practices. Oxford University Press, USA, 1995. 20

[LH07] J.K. Liker and M. Hoseus. Toyota culture: The heart and soul of the Toyota way. McGraw Hill Professional, 2007. 9, 18, 22, 23

[Lik04] J. K. Liker. The Toyota Way. McGraw-Hill, 2004. 8, 9, 10, 11, 12, 13, 14, 15, 16, 17, 20,42

[LM08] K. Logue and K. McDaid. Agile Release Planning: Dealing with Uncertainty in Development Time and Business Value. In 15th Annual IEEE International Conference and Workshop on the Engineering of Computer Based Systems, pages 437-442. IEEE, 2008. 62,64

[lsd] Digest Number 66. Disponível em http://tech.groups.yahoo.com/group/ leandevelopment/message/212. Acessado em: 14/03/2011. 66

[LV09] C. Larman and B. Vodde. Lean Primer. 2009. 10

[LWC04] L. Layman, L. Williams, and L. Cunningham. Exploring extreme programming in context: an industrial case study. In Agile Development Conference, 2004, pages 32-41. IEEE, 2004. 82

[Mag07] D. Magee. How Toyota became\# 1: leadership lessons from the world's greatest car company. Portfolio (Hardcover), 2007. 6

[Mar08] R.C. Martin. Clean code: a handbook of agile software craftsmanship. Prentice Hall PTR Upper Saddle River, NJ, USA, page 448, 2008. 47

[MB00] V.J. Mabin and S.J. Balderstone. The world of the theory of constraints: a review of the international literature. CRC, 2000. 37

[McC93] S. McConnell. Code complete: a practical handbook of software construction, volume 1. Microsoft Press, 1993. 48

[McC07] Steve McConnell. Technical Debt. Disponível em http://blogs.construx.com/ blogs/stevemcc/archive/2007/11/01/technical-debt-2.aspx., 2007. Acessado em 16/06/2011. 28

[Mea06] D. Meadows. Leverage points: Places to intervene in a system. 2006. 23, 26

[MFC05] P. Middleton, A. Flaxel, and A. Cookson. Lean software management case study: Timberline inc. Extreme Programming and Agile Processes in Software Engineering, pages 1297-1298, 2005. 2 
[MGK ${ }^{+}$06] K. McDaid, D. Greer, F. Keenan, P. Prior, P. Taylor, and G. Coleman. Managing Uncertainty in Agile Release Planning. In Proc. 18th Int. Conference on Software Engineering and Knowledge Engineering (SEKE'06), pages 138-143. Citeseer, 2006. 64

[Mid01] P. Middleton. Lean software development: two case studies. Software Quality Journal, 9(4):241-252, 2001. 2

[ML83] J. Malouin and M. Landry. The miracle of universal methods in systems design. Journal of Applied System Analysis 10: 47-62, 1983. 72

[ML06] J.M. Morgan and J.K. Liker. The Toyota product development system: integrating people, process, and technology. Productivity Pr, 2006. 10, 13, 20

[MM05] C. Mann and F. Maurer. A case study on the impact of scrum on overtime and customer satisfaction. In Agile Conference, 2005. Proceedings, pages 70-79. IEEE, 2005. 82

[MR96] W. Mass and A. Robertson. From textiles to automobiles: mechanical and organizational innovation in the Toyoda enterprises, 1895-1933. Business and Economic History, 25:1-38, 1996. 5

[MS03] C. Marchwinski and J. Shook. Lean Lexicon: a graphical glossary for lean thinkers. Lean Enterprise Institute, Inc., 2003. 12

[NA99] J. Nandhakumar and J. Avision. The fiction of methodology development: a filed study of information system development. Information Technology 8 People 12(2): 176-191, 1999. 72

[New98] R.C. Newbold. Project management in the fast lane: Applying the Theory of Constraints. St. Lucie Press Boca Raton, FL, 1998. 66

[NMBW08] N. Nagappan, E.M. Maximilien, T. Bhat, and L. Williams. Realizing quality improvement through test driven development: results and experiences of four industrial teams. Empirical Software Engineering, 13(3):289-302, 2008. 47

[NS09] T. Narusawa and J. Shook. Kaizen Express: Fundamentals for Your Lean Journey. Lean Enterprise Institute, 2009. 14

[NT95] I. Nonaka and H. Takeuchi. The knowledge-creating company: How Japanese companies create the dynamics of innovation. Oxford University Press, USA, 1995. 47

[Ohn88] T. Ohno. Toyota production system: beyond large-scale production. Productivity Press, 1988. 5, 11, 12, 42, 43

[Pat05] J. Patton. It's All in How You Slice It. Better Software Magazine, 2005. 52

[Pat08] J. Patton. User Story Mapping, 2008. Disponível em http://agileproductdesign . com/presentations/user_story_mapping/index.html. Acessado em: 14/03/2011. 52

[PO57] C.N. Parkinson and R.C. Osborn. Parkinson's law, and other studies in administration. Houghton Mifflin, 1957. 34 
[Pop01] M. Poppendieck. Lean programming. Software Development Magazine, 9(5):71-75, 2001. 7

[Pop02a] M. Poppendieck. Principles of lean thinking. OOPSLA Onward, 2002. 2

[Pop02b] M. Poppendieck. The Leadership Paradox, 2002. Disponível em http://www . poppendieck.com/leadership.htm. Acessado em: 14/03/2011. 49

[Pop03a] M. Poppendieck. Lean Software Development. C++ Magazine Methodology Issue, 2003. 46

[Pop03b] M. Poppendieck. Morphing the Mold. Software Development Magazine, 2003. 48

[Pop03c] T. Poppendieck. The agile customer's toolkit. Poppendieck LLC, 2003. note = Disponível em http://www.poppendieck.com. Acessado em: 14/03/2011. 82

[Pop04]～M. Poppendieck. Unjust desserts. Better Software Magazine, 2004. 63

[Pop07] M. Poppendieck. Lean software development. In Companion to the proceedings of the 29th International Conference on Software Engineering, pages 165-166. IEEE Computer Society, 2007. 2

[PP03] M. Poppendieck and T. Poppendieck. Lean software development: an agile toolkit. Addison-Wesley Professional, 2003. 1, 38, 39, 41, 42, 45, 47, 49, 69, 71

[PP05] M. Pikkarainen and U. Passoja. An approach for assessing suitability of agile solutions: A case study. Extreme Programming and Agile Processes in Software Engineering, pages 1202-1206, 2005. 89

[PP06] M. Poppendieck and T. Poppendieck. Implementing Lean Software Development: From Concept to Cash. Addison-Wesley Professional, 2006. 41, 42, 43, 46, 48, 49, 50, $51,53,54,56,60,63,64,70,73,74,75,85$

[PP10] M.B. Poppendieck and T.D. Poppendieck. Leading lean software development: Results are not the point. Addison-Wesley, 2010. 21, 46, 47, 49, 58, 59, 61, 62, 63, 74

[Rah98] S. Rahman. Theory of constraints: a review of the philosophy and its applications. International Journal of Operations \& Production Management, 18(4):336-355, 1998. 24

[RBD03] T. Raz, R. Barnes, and D. Dvir. A critical look at critical chain project management. Project Management Journal, 34(4):24-32, 2003. 24

[Rei97] D.G. Reinertsen. Managing the design factory: a product developer's toolkit. Free Press, 1997. 41, 49, 66, 81

[Rei09] D.G. Reinertsen. The principles of product development flow: second generation lean product development. Celeritas, 2009. 62

[Ric07] W. S. Richard. Software engineering: Barry W. Boehm's lifetime contributions to software development, management, and research Practitioners Series. Wiley-IEEE, 2007. 48 
[Rie11] E. Ries. The Lean Startup: How Today's Entrepreneurs Use Continuous Innovation to Create Radically Successful Businesses. Crown Business, 2011. 81

[RME01] J. Rubinstein, D. Meyer, and J. Evans. Executive control of cognitive processes in task switching. Journal of Experimental Psychology, 27(4):763-797, 2001. 44

[RS03] M. Rother and J. Shook. Learning to see. Lean Enterprise Institute, 2003. 22

[Sat07] D. T. Sato. Uso eficaz de métricas em métodos ágeis de desenvolvimento de software. Master's thesis, Instituto de Matemática e Estatística da Universidade de São Paulo - IME/USP, 2007. 1, 41, 47, 53, 60, 64

[SB99] S. Spear and H.K. Bowen. Decoding the DNA of the Toyota production system. Harvard Business Review, 77:96-108, 1999. 18

[SB02] K. Schwaber and M. Beedle. Agile software development with Scrum, volume 18. Prentice Hall Upper Saddle River, NJ, 2002. 47, 51, 59

[SC04] K. Schwaber and Microsoft Corporation. Agile project management with Scrum, volume 7. Microsoft Press Redmond, WA, 2004. 51, 89

[Sch98] P.R. Scholtes. The leader's handbook: making things happen, getting things done. McGraw-Hill Companies, 1998. 20

[Sch10] List J. Scheinkopf. Thinking Processes Including ST Trees (Chapter 25 of Theory of Constraints Handbook). McGraw-Hill Professional, 2010. 26

[Sen06] P.M. Senge. The fifth discipline: The art and practice of the learning organization. Broadway Business, 2006. 17, 38

[Shi85] S. Shingo. A revolution in manufacturing: the SMED system. Productivity Press, 1985. 7

[Shi89] S. Shingo. A study of the Toyota production system from an industrial engineering viewpoint. Productivity Press, 1989. 18, 42, 46

[Sir02] D. Sirias. Writing MIS Mini-Cases To Enhance Cooperative Learning: A Theory Of Constraints Approach. Journal of Information Systems Education, 2002. 74

[Sit] Relations with Stakeholders. Disponível em http://www.toyota.co.jp/en/csr/ relationship/partners.html. Acessado em: 14/03/2011. 16

[Sky01] L. Skyttner. General systems theory: ideas $\&$ applications. World Scientific Pub Co Inc, 2001. 51

[Sma] A. Smalley. A Brief History of Set-Up Reduction. Disponível em http://www. artoflean.com. Acessado em: 14/03/2011. 7

[SO91] X. Song and L. J. Osterweil. Comparing design methodologies through process modeling. In 1st International Conference on Software Process. IEEE Computer Society, 1991. 72

[SRC07] T. T. Sullivan, R. A. Reid, and B. Cartier. TOCICO Dictionary, 2007. Disponível em https://www.tocico.org. 26 
[Ste01] H. Steyn. An investigation into the fundamentals of critical chain project scheduling. International Journal of Project Management, 19(6):363-369, 2001. 24

[SW07] J. Shore and S. Warden. The art of agile development. O'Reilly Media, 2007. 49

[SWL99] D.K. Sobek, A.C. Ward, and J.K. Liker. Toyota's principles of set-based concurrent engineering. Sloan Management Review, 40(2):67-84, 1999. 20

[SWS06] E. Schragenheim, A. Weisenstern, and A. Schragenheim. What's really new in Simplified DBR. In TOCICO international conference, Las Vegas, NV, 2006. 32

[Tas02] G. Tassey. The economic impacts of inadequate infrastructure for software testing. National Institute of Standards and Technology, RTI Project, 2002. 46

[TBT01] D. P. Truex, R. Baskerville, and J. Travis. A methodological systems development: The deferred meaning of systems development methods. Accounting, Management and Information Technology, 2001. 72

[Thi02] H. Thimbleby. Delaying commitment. Software, IEEE, 5(3):78-86, 2002. 48

[Tho] C. Thompson. Learn to Let Go: How Success Killed Duke Nukem. Wired. Disponível em http://www.wired.com/magazine/2009/12/fail_duke_nukem/all/1. Acessado em: 14/03/2011. 46

[TMMK06] Inc. Toyota Motor Manufacturing Kentucky. History, 2006. Disponível em http: //www.toyotageorgetown.com/history.asp. Acessado em: 14/03/2011. 7

[TN86] H. Takeuchi and I. Nonaka. The new new product development game. Harvard Business Review, 64(1):137-146, 1986. 1, 49

[UU00] M. Umble and E. Umble. Manage your projects for success: An application of the theory of constraints. Production and Inventory Management Journal, 41(2):27-32, 2000. 24

[War89] A.C. Ward. A theory of quantitative inference applied to a mechanical design compiler. 1989. 20

[War07] A.C. Ward. Lean product and process development. Lean Enterprises Inst Inc, 2007. 45

[WBG07] K.J. Watson, J.H. Blackstone, and S.C. Gardiner. The evolution of a management philosophy: the theory of constraints. Journal of operations management, 25(2):387402, 2007. 24

[Wei75] G.M. Weinberg. An introduction to general systems thinking. Wiley-Interscience, 1975. 37

[Wei92] G.M. Weinberg. Quality Software Management, Volume I: Systems Thinking. Dorset House, 1992. 44

[WGGD10] D. West, T. Grant, M. Gerush, and D. D'Silva. Agile Development: Mainstream Adoption Has Changed Agility. Forrester Research, 2010. 2, 41 
[wik] Student Syndrome. Disponível em http://en.wikipedia.org/wiki/Student_ syndrome. Acessado em: 14/03/2011. 34

[WJ03] J.P. Womack and D.T. Jones. Lean thinking: banish waste and create wealth in your corporation. Free Press, 2003. 5, 8, 10, 11, 20, 21, 42

[WJR91] J.P. Womack, D.T. Jones, and D. Roos. The machine that changed the world: the story of lean production. Productivity Press, 1991. 5, 8

[WK02] L. Williams and R. Kessler. Pair programming illuminated. Addison-Wesley Longman Publishing Co., Inc. Boston, MA, USA, 2002. 47

[WLCS95] A. Ward, J.K. Liker, J.J. Cristiano, and D.K. Sobek. The second Toyota paradox: How delaying decisions can make better cars faster. Sloan Management Review, $36: 43-43,1995.20$

[WW09] D. West and R.C. Wildeman. Product-Centric Development Is A Hot New Trend. Technical report, Forrester Research, 2009. 81 